Portland State University

PDXScholar

\title{
From the Printing Press to the Guillotine: Gracchus Babeuf and the Revolutionary Language of Thermidor
}

David Brian Audley

Portland State University

Follow this and additional works at: https://pdxscholar.library.pdx.edu/open_access_etds

Part of the European History Commons

Let us know how access to this document benefits you.

\section{Recommended Citation}

Audley, David Brian, "From the Printing Press to the Guillotine: Gracchus Babeuf and the Revolutionary Language of Thermidor" (1997). Dissertations and Theses. Paper 5740.

https://doi.org/10.15760/etd.7611

This Thesis is brought to you for free and open access. It has been accepted for inclusion in Dissertations and Theses by an authorized administrator of PDXScholar. Please contact us if we can make this document more accessible: pdxscholar@pdx.edu. 


\section{THESIS APPROVAL}

The abstract and thesis of David Brian Audley for the Master of Arts in History were presented February 14, 1997, and accepted by the thesis committee and the department.

COMMITTEE APPROVALS:

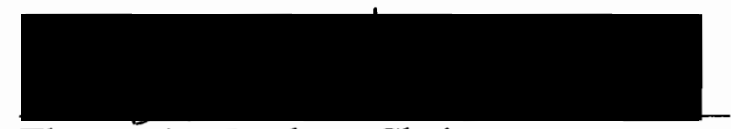

Thomas M. Luckett, Chair

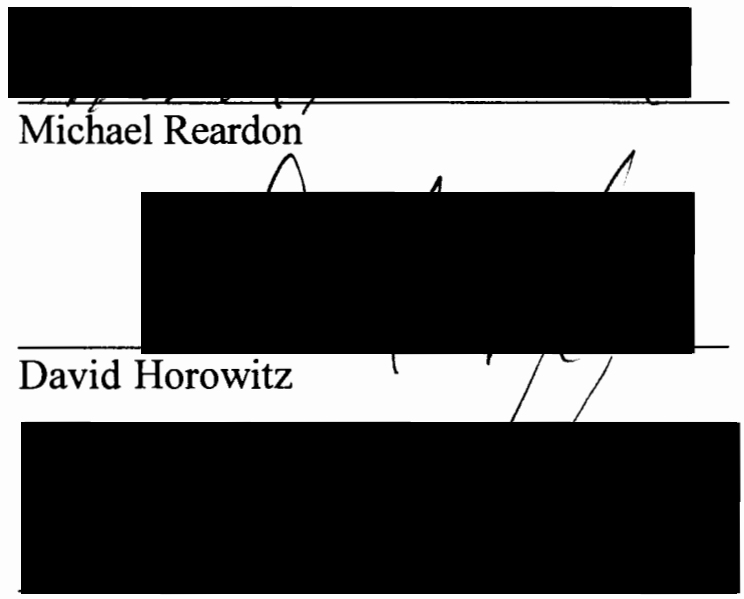

Robert Liebman

Representative of the Office of Graduate Studies

DEPARTMENT APPROVAL:

GQrdon Dodds, Chair

Department of History

ACCEPTED FOR PORTLAND STATE UNIVERSITY BY THE LIBRARY
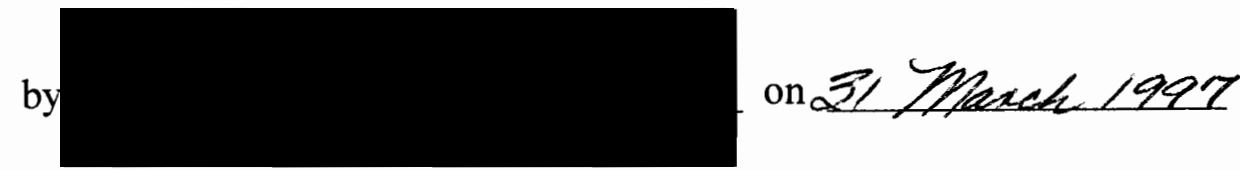


\begin{abstract}
An abstract of the thesis of David Brian Audley for the Master of Arts in History presented February 14, 1997.
\end{abstract}

Title: From the Printing Press to the Guillotine: Gracchus Babeuf and the Revolutionary Language of Thermidor.

The traditional history of François-Noël 'Gracchus' Babeuf has been centered on politics and socialism. Sine his death in 1797 historians have attempted to show the foundations of nineteenth and twentieth-century social revolution and communism in the polemical works of Babeuf. One result of this method of research has been an assumption of contradiction within Babeuf's writings in the months immediately following the fall of Maxmilien Robespierre. Historians have assumed that the seemingly anti-Robespierrist rhetoric found from September 1794 to February 1795 was both a product and an evidence of the 'Thermidorization' of Babeuf. However, a close textual analysis of several of Babeuf's tracts proves that Babeuf was both a committed Jacobin and Robespierrist throughout the Thermidorian reaction.

What enabled Babeuf the Jacobin to appear 'Thermidorian' was his unique usage of language. By infusing the traditional language of denunciation with a complex and dualistic representation of both Robespierre and the Jacobins, Babeuf 
simultaneously and paradoxically praised their historic virtue of 1789 and condemned their political corruption in 1794.

Through and examination of three of Gracchus Babeuf's pamphlets, Les battus payant amende, On veut sauver Carrier, and Voyage des jacobins, a clearer and more precise image of Babeuf the journalist arises. These works evidence two distinctive linguistic discourses: a rhetoric of religion and a language of opposition. Through his systematic usage of images and symbols Babeuf exhibits a unique philosophical and religious continuity between Jansenist and parlementary opposition to absolutism and republican criticism of the monarchy. From this religious origins grows Babeuf's journalistic position as voice of Thermidorian opposition and criticism. The symbolic language of Babeuf evidences the steady evolution of journalistic opposition that originated with the libellistes of the Ancien Régime, grew in popularity under Hébert and Armand Guffroy, and ultimately rallied the disparate remnants of the Mountain to the pages of Babeuf and le Tribun du Peuple. 


\title{
FROM THE PRINTING PRESS TO THE GUILLOTINE:
}

\author{
GRACCHUS BABEUF AND THE \\ REVOLUTIONARY LANGUAGE OF THERMIDOR
}

by

DAVID BRIAN AUDLEY

A thesis submitted in partial fulfillment of the

requirements for the degree of

\author{
MASTER OF ARTS \\ in \\ HISTORY
}

Portland State University

1997 


\section{TABLE OF CONTENTS}

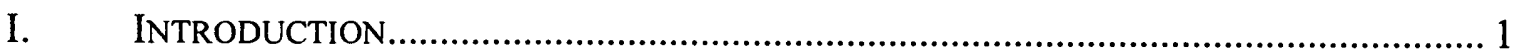

From Marxism To Revisionism:

The Historiography Of Babeuf

II. PRINTED PoISON

Babeuf, the Radical Press and the Language of Denunciation

From Thermidor to the Ancien Régime

III. 'If LiBerTy Perishes HeRE'

Babeuf, the Imprimerie de Franklin and the Revolutionary

Language of The Thermidorian Reaction

IV. From CRITIC TO APOLOGIST.

Babeuf, Popular Socities, and

The Re-Invention of Maxmilien Robespierre

V. CONCLUSION

Words that Foment Revolution:

The Legacy and Execution of Gracchus Babeuf

APPENDIX

I. Timeline of Babeuf, his Publications, and the Thermidorian reaction.

II. The Publications of F.-N. 'Gracchus' Babeuf, 1789-1796 ............................... 156

III. Babeuf and Critical Theory:

The Study of Revolutionary Language 
$\therefore$ the existence of young men of the lower classes with education above their rank made Robespierre's return particularly likely.'

-Stendahl, Scarlet and Black.

This thesis draws off eighteen months of research. The number of people to whom I am indebted for the time, resources, and encouragement in the completion of this work is great. I would like to thank Professors Charles LeGuin and Michael Reardon for the foresight in knowing that some student would someday make use of the microfiche collection of François-Noël 'Gracchus' Babeuf's pamphlets and writings. I would also like to thank Professor Thomas Luckett for his vision and drive. It was an initial query of Dr. Luckett that drove me to examine Babeuf, and his support and encouragement that convinced me that I could re-write two hundred years Babouvist historiography. I also must acknowledge George Eigo, Sam Byers, and especially Carina Amlie for endless support, true camaraderie, and wonderful friendship. This work would not have been completed without the esteem of my fellow students as we struggled towards a common, seemingly unreachable, and always inconceivable goal of both composing history and convincing our families that graduate school is a viable career path. I would also like to thank my parents and family whose constant questions about my research and occupation have made me more aware and committed to studying the French Revolution. This work is, however, dedicated to my sweet and loving wife, Erin, whose patience I have tried for too long, and whose love is a constant reminder that there are things more important than Gracchus Babeuf and the revolutionary language of Thermidor. 


\section{INTRODUCTION:}

From Marxism to Revisionism:

the Historiography of Babeuf

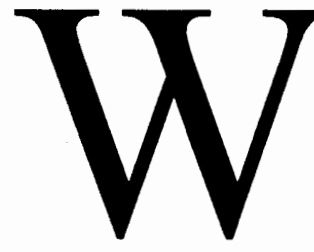

ho is Gracchus Babeuf? Since his execution on 27 May 1797, a shroud of obscurity has lowered over the revolutionary career of this feudiste turned journalist. He has been named the precursor of Marxist totalitarianism ${ }^{1}$ and the first revolutionary communist. ${ }^{2}$ What has yet to be established in the two hundred years since his death, is the significant difference between Babeuf the pamphleteer, and Babeuf the condemned conspirator. It is the latter Babeuf who fills the histories from Filippo Buonorotti to François Furet. It is, however, the former who is the center of this research.

From the Printing Press to the Guillotine is an examination of the rhetoric, discourse, and revolutionary language of François-Noël ‘Gracchus’ Babeuf from September 1794 to February 1795 . It is in this period of the Thermidorian regime that

${ }^{1}$ See J. L. Talmon, The Origins of Totalitarian Demecracy, trans. Jacob Lieb, (New York: Praeger, 1960).

${ }^{2}$ See R.B. Rose, Gracchus Babeuf The First Revolutionary Communist, (Stanford: University Press, 1978). 
Babeuf composed his most complex, paradoxical, and imaginative polemical tracts. These pamphlets, 'these brief, self-contained' publications intended to 'influence public opinion' through an examination of a 'fairly narrow range of issues, ${ }^{3}$ are some of the greatest possible, and yet least utilized, venues for research of Gracchus Babeuf.

It is within these highly political tracts that a specific and coherent discourse arises. It is the unity of Babeuf's mentality, as shown through his journalism, that frames this thesis. The 'revolutionary language' of Babeuf utilized within the tracts examined here is a discourse based on metaphor, allusion, and denunciation. Chapter II, Printed Poison, evidences the continuity of Babeuf's rhetoric in le Journal de la Liberté de la presse and le Tribun du Peuple by examining the language of denunciation found in the journals le Père Duchesne and le Rougyff. Chapter III, 'If Liberty Perishes Here', shows the evolution of Babeuf's vision of corrupted versus pure Jacobinism by analyzing the pamphlets On veut sauver Carrier, Les battus payant amende, and Voyage des jacobins. In From Critic to Apologist,(Chapter III), the synthesis of Babeuf's anti-Thermidorian rhetoric is shown in its final and most powerful manifestation: the re-invention of Maxmilien Robespierre as a pure and uncorrupted patriot. It is Babeuf's complex system of linguistic insinuation and allegory that allows for the paradoxical praise of a pure and virtuous philosophy and the simultaneous condemnation of its political corruption.

${ }^{3}$ Harvey Chisick, "Pamphlets and Journalism in the Early French Revolution" French Historical Stidies, Vol. XV, ${ }^{\circ} 4$, (Fall, 1988): 625. 
What makes this terminology revolutionary is its obvious attempt to reform and reinvent society. The pamphlets of Babeuf are filled with historical legend. His writings use allusion to elucidate a classical, civic, and republican virtue, and to eschew the indulgence, immorality, and vice of privilege. The image of Babeuf that arises from these pages is that of an intricate and deeply puritanical writer haunted by social inequity.

However, this vision of Gracchus Babeuf stands at odds with the majority of his historiography. The writings of Babeuf in the months after the fall of Maxmilien Robespierre contain little of the proto-communist ideology and jargon celebrated from Marx to Michael Harrington. ${ }^{4}$

François-Noël 'Gracchus' Babeuf:

Historiography and Marxism.

Marx and Engels paid homage to Gracchus Babeuf in their The Holy Family as the conduit by which the utopian ideals of the Enlightenment were moved into the political consciousness of the modern era. Marx's statement that 'The Revolutionary movement, that began in 1789 with the Cercle Social ... was completed with the conspiracy of Babeuf, ${ }^{5}$ is one of the most significant elements in the creation of a

${ }^{4}$ See Michael Harrington, Socialism, (New York, Saturday Review Press, 1970).

${ }^{5}$ Karl Marx, and Frederich Engels, La Sainte famille, (Ouveres, tome II), 132. 
political historiography of Babeuf. Similarly, when Leon Trotsky proclaimed Babeuf 'the first in a long line of revolutionary heroes and martyrs, ${ }^{6}$ the division between Babeuf the man and Babouvism the ideology became increasingly obscure.

Almost since its inception, the study of Babeuf has been dominated by Marxist scholars. The victory of the Bolshevik revolution, however, lifted Gracchus Babeuf to a new level of obscured eminence. With his first article, Soviet historian V.-P. Volguine recast the revolutionary career of Babeuf to support Bolshevik claims of historic legitimacy. Published less than six years after the Russian Revolution, Volquine's L'héritage idéologique du babouvisme is the first systematic attempt to show a Marxist revolutionary foundation within the ideology of Babeuf. ${ }^{7}$ Volguine's argument is an attempt to establish a distinct and permanent line between the transformation of society advocated during Babeuf's defense for the High Court at Vendôme in 1797 and the Soviet Revolution in Russia in 1918. Volquine was the first historian to argue that the bonheur commun of Babeuf's Conspiracy of Equals is the historic prognosticator of Leninist collectivism.

Volguine's argument is a masterpiece of Soviet historicism. Volguine had invented in Babeuf a revolutionary hero who could be rewritten to embody the pure virtue of communism without the Robespierrist taint of bourgeois morality. From its

${ }^{6}$ R.B. Rose, Gracchus Babeuf: The First Revolutionary Communist, (Stanford: University Press, 1978), 1.

7 Victor M Daline, "L'Historiographie de Babeuf." La Pensée, Vol. 128, (1966): 85. 
publication in 1922, Volguine's research set the standard for the interpretation of Babeuf as a Marxist-Leninist icon.

Babeuf and the 1930s:

The Transition from Mathiez to Dommanget

Building on Volquine's foundation, other historians have approached Babeuf with the dogmatic eye of Marxism. From 1922 to 1970, the list of historians who have published articles and books on Babeuf reads like a socialist party roster: Victor Daline, Maurice Dommanget, Albert Mathiez, Georges Lefebvre, Albert Soboul, and R. B. Rose. Though the research on Babeuf by these historians has been extensive, it is arguable that Babeuf's historiography is incomplete. By examining Babeuf with the intent to show his nascent socialism, Mathiez, Lefbevre, and Soboul have each crafted histories through a selective reading of pamphlets. The result, however, is the creation of two distinct images of Babeuf. Though Mathiez, Lefebvre, and Soboul all claim Babeuf as a proto-socialist, the role of Robespierre and the sans-culottes within his discourse is systematically transfigured between the 1930 s and the 1960 s.

Albert Mathiez was the first twentieth century French historian to approach Babeuf from a dogmatic stance. Mathiez claims that Babeuf, as early as 1791, was a convinced communist. The political connection between Robespierre and Babeuf, Mathiez asserts, was conceived from a shared aversion to the property qualification for 
active citizenship. ${ }^{8}$ There is, in addition, a mutual ideology between Robespierre and Babeuf. Mathiez argues that a common desire for the abolition of primogeniture set the precedent to conceive of both Babeuf and Robespierre as the precursors of modern socialism. $^{9}$

Mathiez was also one of the few French historians to argue that the majority of the discourse of Babeuf was Robespierrist. Though not uncritical of Babeuf's role in the early months of the Thermidorian regime, Mathiez laid a simple thesis in his The Fall of Robespierre (1927), for the political adroitness Babeuf. Mathiez believes that Babeuf's criticism of Robespierre in le Journal de la Liberté de la presse resulted from the political necessity to distance himself 'from such a compromising name.' 10 However, Mathiez states that Babeuf never intended to remove himself from the ideal of the Robespierrist regime. Though Mathiez does not examine the evolution of Babeuf from critic to apologist, he is the first historian to argue for the existence of a complexity in Babeuf's paradoxical discourse.

With the death of Mathiez in 1932, the mantle of French Revolutionary history was passed to Georges Lefebvre and ultimately to Albert Soboul. Whereas Mathiez was committed to showing Babeuf's socialism by casting him as a defender of

${ }^{8}$ Albert Mathiez, The French Revolution, trans. Catherine Alison Phillips, (New York: Grosset and Dunlap, 1956), 211.

${ }^{9}$ Ibid., 207.

${ }^{10}$ Albert Mathiez, The Fall of Robespierre, (New York: Alfred Knopf, 1927), 236. 
Robespierre, Lefebvre and Soboul's research was less inclined to overlook vicious anti-Robespierrist rhetoric of le Journal de la Liberté de la presse.

Within five years of Mathiez's death, the study of Babeuf underwent a tremendous transformation. Beginning with Georges Lefebvre's Les Thermidoriens in 1937, Babouvist historiography began to dismiss Mathiez's complexity theory. Instead of examining the works of Babeuf with the intent to show his subtle Jacobin rhetoric, Lefebvre sought to show Babeuf as a political chameleon who readopted the guise of Jacobinism only when isolated from the Thermidorian regime.

The most significant research in this transformation of Babeuf was the 1935 publication of Maurice Dommanget's Pages choisies de Babeuf. With this work, historians were given greater access to the polemics and politics of Gracchus Babeuf. Dommanget's book, far from reproducing the entirety of Babeuf's work, is a selection of short sections of Babeuf's massive polemical publications. Dommanget divided the career of Babeuf into eight distinct segments. The complete works of Babeuf were then edited to match the political divisions conceived by Dommanget. ${ }^{11}$

Though a tremendous overview of Babeuf, it is an imperfect representation of his journalistic career. With few pamphlets and articles reproduced in their entirety, research into the revolutionary career of Babeuf from 1935 to the present has been

${ }^{11}$ Dommanget divides his work into: 1) Babeuf's correspondence with the Academy of Arras, 2) le Cadastre Perpétuel, 3) le Correspondant Picard, 4) Adminstrator of Somme, 5) the Thermidorian reaction, 6) Imprisonment in Arras, 7) Failure under the Directory, 8) Imprisonment and Trial at Vendôme. 
conducted in relative isolation. As a result, pamphlets like Les battus payant amende, On veut sauver Carrier, and Voyage des jacobins have never been given the examination, analysis, and consideration that they deserve.

From these tracts, it is obvious that the discourse and language of Babeuf, at least during the Thermidorian reaction, is in an almost constant state of evolution and flux. It is difficult, therefore, to derive any fundamental understanding of the cultural or social politics of Babeuf by reading his pamphlets without context. By an examination of these tracts in isolation, the continuity and evolution of Babeuf's discourse is lost.

Though Dommanget himself admits that 'these pages have only one object: to permit an appreciation of these texts, ${ }^{12}$ they have been utiiized since their publication as the primary source for Babouvist research. A survey of the footnotes of historians from Kåre Tønnesson in the 1950s to Branislaw Baczko in the 1990s evidences an almost orthodox dependence on the pages choisies. ${ }^{13}$ It is, however, the research of

${ }^{12}$ Maurice Dommanget, Pages choisies de Babeuf, (Paris: Libarie de Armand Colin, 1935), 1.

${ }^{13}$ Dommanget's compilation is arguably the most influential and cited work on Babeuf. A short list of works that have relied on Dommanget's pages choisies inclueds: D. Woronoff's The Thermidorian regime and Directory, (1972), M. Slavin's Bourgois, Sans-culottes, and other Frenchmen, (1981), I. Wolloch's Jacobin Legacy, (1970), V. Daline's "Robespierre et Danton vue par Babeuf" (1960), K. Tønnesson's "L'An III dans la formation du babouvisme" (1960) and La defaite des sans-culottes, (1959), B. Bazcko's Ending the Terror, (1994), R.B. Rose's Gracchus Babeuf, (1978) as well as J. Godechot's "Les travaux récents sur Babeuf et le babouvisme." (1960). 
Albert Soboul and Georges Lefebvre that have contributed most to the political historiography of Babeuf.

Soboul and Lefebvre:

The Criticism and Apology of the Communist Babeuf.

Soboul agrees with Mathiez's assertion of Babeuf's communism. Soboul argues that Babeuf was the first person to 'overcome the contradiction . . . between the assertion of the right to existence on one hand, and the maintenance of private property and economic freedom on the other. ${ }^{14}$ Soboul continues to read into Babeuf's earliest work, le Cadastre perpétuel, a nascent ideology of communism and collectivism. Soboul makes a difficult argument that Babeuf, 'the son of an excise officer and an illiterate serving girl' was wholly self-taught. Soboul continues that Babeuf was able to glean from the pages of Rousseau, Mably, and Morelly's Code de la nature a sophisticated ideological system of 'collective farms' and 'fraternal communities. ' 15 The fragility of Soboul's argument is evidence of its ideological structure. Soboul attempts to cast Babeuf as a product of a rural peasantry. This origin, Soboul appears to argue, enhances Babeuf as a pure embodiment of agricultural communism. Neither

${ }^{14}$ Albert Soboul. The French Revolution, 1789-1799: From the Storming of the Bastille to Napoleon, (New York: Random House, 1974), 487.

${ }^{15}$ Ibid., 488. 
Soboul nor Georges Lefebvre appears to understand the historical deficiency of reading nineteenth-century reasoning into eighteenth-century comprehension.

Where Soboul argues that Babeuf presents an early form of agricultural communism, ${ }^{16}$ Lefebvre asserts that Babeuf advocated an advanced form of economic and proto-industrial socialism. ${ }^{17}$ Lefebvre suggests that it is with Babeuf that socialism left the realm of 'literary utopia' and entered 'political history., 18 Lefebvre's reading of Babouvist theory under Thermidor and the Directory is one of the great works of historical redefinition. ${ }^{19}$ Lefebvre asserts that Babouvist ideology transformed itself in 1796 into an urban based communism of distribution. Lefebvre continues that this transformation was implemented when Babeuf realized that the 'strong urge to own property' present in the eighteenth-century peasant was a restraint

${ }^{16}$ Soboul's notion of a collective communism has a foundation within the writings of Babeuf. Soboul's selective reading of le Cadastre Perpetéul shows that Babeuf advocated a moderate form of the agrarian law. Babeuf called in 1789 for the division of all arable lands in France. Babeuf envisioned the equal distribution of lands to all the families within the nation. Babeuf belived that this disvison would accomplish two specific needs: the creation of a nation of farmers who would work for the common good of the state, and the codification of the value of all taxable farmland in France.

${ }^{17}$ Lefebvre reads the evidence presented at the trial of Babeuf before the High Court of Vendôme as a validation of a state controlled economy. Babeuf's presumed advocation of communal storehouses and labor, Lefebvre asserts, would result in a early soviet system of labor controlled industry.

${ }^{18}$ Georges Lefebvre, The French Revolution from 1793-1799, Vol II. trans. John Hall Stewart and James Friguglietti, (New York: Columbia University Press, 1964), 175.

${ }^{19}$ See Georges Lefebvre, Les Thermidoriens, (Paris: Max Leclerc et Cie, 1964) and Le Directoire, (Paris, Max Leclerc et Cie, 1946). 
to the creation of true equality. ${ }^{20}$ The Babouvist response to this reality, Lefebvre claims, is seen in the notion of communal store houses: peasants would continue to work the land while the fruits of the fields would be equally distributed to the whole of the nation. The ultimate result of this structure, Lefebvre appears to argue, would be the harnessing of the rural population into a state-controlled system of agriculture. This system would provide the necessary food-stuffs to fuel an urban industrialization.

Though Lefebvre correctly argues the Babouvist mechanism of collectivization, his analysis of the reasoning and ideology is flawed. There is no evidence of Lefebvre's urban suspicion of the rural peasantry within the writings of Babeuf. Neither is there an advocating of industrialism. What Lefebvre and Soboul fail to recognize it that the ideology of Babeuf was conceived in the fields and the archives of rural Picardy. Babeuf was not a forward looking social engineer who sought a new day of urban expansion. He was, rather, convinced of the need to emend the inequality of society through the reform of land and agriculture. If the alleged conspiracy had succeeded, ${ }^{21}$ the resulting socio-political implications would have caused a massive ruralization of the French population. With each family guaranteed an equal measure of arable farmland, France would, for a single generation, have been a nation of

20 Ibid.

${ }^{21}$ See F.-N. 'Gracchus' Babeuf, The Defense of Gracchus Babeuf before the High Court of Vendôme, trans. John A. Stewart, intro. Herbert Marcuse, (New York: Schocken Books, 1967) for a wonderful analysis and translation of the trial of Babeuf after the alleged Conspiracy for Equality in 1796-97. 
subsistence farmers. The ideology of Babeuf under Thermidor and the Directory, if implemented, would have retarded the slow progression of France towards industrialization. 
Babeuf and the Nineteenth Century:

From Juarès to Buonorotti. ${ }^{22}$

However, the selective reading of Babeuf is not entirely a product of the twentieth century. Historians of the nineteenth century approached Babeuf from a unique perspective that was similarly inclined to praise or condemn Babeuf for his politics. From the initial publication of Filippo Bounorotti's History of Babeuf's Conspiracy for Equality in 1828, the historiography of Babeuf was veiled in political ideology. From Buonorotti to Jean Juarès, nineteenth-century historians struggled to place the Enlightenment based Babouvist ideology into the scientific cosmology of nineteenthcentury class revolution. The resulting historiography was one that strove to read backwards into Babeuf a mentality and political consciousness that better suited the bourgeois realities of post-Napoleonic Europe.

Hippolyte Taine, in his Origines de la France contemporaine, published in 1887 , appears as one of the great critics of Babeuf. Taine unequivocally defines Babeuf as the 'the grand apostle of authoritarian communism. ${ }^{23}$ Taine describes a tremendous continuity in the ideology of Babeuf. For Taine, there is no level of

${ }^{22}$ One of the difficulties in researching the historiography of Babeuf is finding sources from the nineteenth century that libaries are willing to loan out to master's students from a university in Portland, Oregon. Thus, this section is based very heavily upon a 1966 article by the Soviet historian Victor Daline. Though I disagree with Daline's strict political reading of Babeuf, his research is an excellent overview of the historical evolution of the historiography of Babeuf.

${ }^{23}$ Daline, "L'Historiographie de Babeuf.": 74. 
evolution from primitive agrarianism to communism. Taine reads even the earliest pamphlets of Babeuf as testaments to the feared agrarian law and collectivism.

Jean Juarès, however, in his Histoire socialiste de la Révolution francaise, finds no such consistency. Though Juarès presents an extremely sympathetic view of Gracchus Babeuf, there is a palpable level of disappointment in this history. As a socialist writing a socialist history of France, Jaurès is noticeably upset that he could find no hints of the coming 'communist' rhetoric of year $\mathrm{V}$ in early polemics of Babeuf. He writes:

Mais dans la riche effervescence d'idées qui marque ces premiers mois de 1793, où est l'idée communiste? Dans les plans de Constitution qui abondent vers le Comité de la Convention, je ne vois pas la plus moindre allusion au Code de la nature de Morelly, je ne vois pas la plus moindre esquisse de ce que sera demain le babouvisme. Que fait donc Babeuf, et serait-il vrai, comme le dit Boudot, que le communisme ne fut dans la Révolution française qu'une sorte d'accident, une secte d'origine et d'importation étrangère? ${ }^{24}$

However, the history of Babeuf presented by Juarès is obviously produced in an effort to cast the character of the man as an ideology. Juarès refused to accept Babeuf as either an accident or a foreign invention. It was, for Juarès, the final embodiment of Jacobinism.

It was Emile Coët, however, who produced the version of Babeuf that would later be absorbed by social moderates. In his work Babeuf à Roye, published in 1880, Coët recognized the courage of Babeuf to criticize the direction of the Revolution

${ }^{24}$ Ibid., 82. 
during Thermidor. Coët further argued that though Babeuf was a great patriot, his role within the Revolution was imperfect. Regardless that the Conspiracy of Equals provided the necessary foundation for the growth of socialism, Coët argues that Babeuf was tainted by the very complicity in the Terror that Jaurès celebrates. ${ }^{25}$

In his Histoire populaire de la Révolution française, published in 1840, Etienne Cabet signaled a remarkable variation in the nineteenth-century presentation of Babeuf. In a special chapter dedicated to his revolutionary career, Cabet was both hostile and critical of the role of Babeuf. The main thrust of Cabet's attack was that the Babouvist ideal that violence was a necessary component of communism was immoral and inhumane. ${ }^{26}$ The conspiracy was no more than a re-invented Terror. Though the outcome was intended to be more egalitarian, the method was still Jacobinical.

Cabet's assessment of Babeuf initiated the first great historiographic conflict over the career of Babeuf. This argument resulted in a violent and dogmatic condemnation of Cabet by a new political ideology that identified itself as neobabouvist. The first great historiographic controversy about Babeuf was instigated by Cabet's stinging remark:

Pourqoui, pour representer une doctrine qu'on croit la plus belle et la plus parfaite choisir un homme qui peut n'être pas parfait et dont la vie, attaquée par une partie de patriotes eux-mêmes peut fournir au moins des prétextes aux attaques des adversaries

${ }^{25}$ E Coët, Babeuf à Roye, (Peronne: 1885), as cited by Daline, "L'Historiographie de Babeuf.": 77.

${ }^{26}$ Etienne Cabet, Histoire Populaire de la Révolution française, Vol IV. (Paris, 1840), as cited by Daline, “L'Historiographie de Babeuf.": 76. 
de la Communuaté?... Transformer le Communisme en Babouvisme, n'est-ce pas donner dans un piège, et augmenter comme à plaisir des difficultés déjà si grandes? ${ }^{27}$

Theodore Dézamy, writing in Calomnies et politique de M. Cabet, refuted Cabet's representation of Babeuf as both a minor political actor and an 'ultra-Thermidorian. ${ }^{28}$

It is widely accepted that the historiography of Babeuf began with the publication, in 1828, of Filippo Buonorotti's 'remarkable book.' ${ }^{29}$ Daline argues that it is from the pages of Buonorotti's Conspiration pour l'Egalité that the most truthful vision of Babeuf arises. It is Buonorotti's memoir that provides the only eye-witness account of the ideology of Gracchus Babeuf. There is, however, a much earlier example of this witnessed historiography of Babeuf. Written and published by Babeuf on 19 Nivoise, III, the pamphlet G. Babeuf/Tribun du Peuple, à ses concitoyens is the first work that details the evolution of Babeuf's revolutionary mentality.

Written as a response to the attacks committed against his character by Fréron, Tallien, Guffroy, and the other deputies of the Thermidorian National Convention, this pamphlet lays the foundation for the fabrication of Babeuf's revolutionary career. This work is dedicated to the reconstitution of Babeuf's activities from 1789 to 1795 . The work is largely hagiographic. ${ }^{30}$ It was conceived in order to demonstrate Babeuf's

\section{${ }^{27}$ Ibid., 304-05.}

${ }^{28}$ Theodore. Dézamy, "Calomnies et politique de M. Cabet. Réfutation par des faites et par sa biographie." in Sur l'attitude de Cabet envers Babeuf et le babouvisme, (Paris: 1842), as cited by Daline, "L'Historiographie de Babeuf.": 76.

${ }^{29}$ Daline. "L'Historiographie de Babeuf.": 73.

${ }^{30}$ Though 'hagiography' is generally defined as a saint's life, its meaning here is the intentional creation of selective and politically oriented history. 
glorification and celebration of the Revolution. It is written as well as a vehicle to separate the reborn radical Babeuf from his moderate Thermidorian origins.

From this pamphlet arises an important evidence of Babeuf's complete rupture and disillusionment with the Thermidorian regime. Babeuf writes that:

From the depths of my dungeon ... it has permitted me to dissipate the horrible lies that many have poured on me to have the pretext to put me in chains ... Here it is. Here is my response. ${ }^{31}$

Babeuf articulates in this pamphlet his evolution from a profiteer to patriot. It was, Babeuf writes, as a feudiste ${ }^{32}$ during the ancien régime:

in the seigniorial archives that I discovered the horrible mysteries of the ursurpations of the nobles caste. ${ }^{33}$

It is from the lines of this pamphlet that some of the most fundamental aspects of Babeuf are first articulated. Here Babeuf announces his 'devotion to the sansculottes' of Paris and his 'rage, when ... he is reminded of the counter-revolutionary spirit' $^{34}$ that aligned perpetually against the liberty of the people.

It is also within the pages of this tract that Babeuf seeks to minimize his own level of education. ${ }^{35}$ He states that both he and his wife Marie-Anne have no great

${ }^{31}$ F-N. 'Gracchus'Babeuf, G. Babeuf / Tribun du Peuple à ses Concitoyens, (Paris: Franklin, rue de Clery 75, 1795), 1.

${ }^{32}$ The pre-Revolutionary career of Babeuf is analyzed and discussed in greater detail in Chapter II.

${ }^{33}$ Ibid.

${ }^{34}$ Ibid., 3.

${ }^{35}$ See Maurice Dommanget, "Babeuf et l'éducation." Annales Historiques de la Révolution Française, $\mathrm{n}^{\circ}$ 162, (1960): 534-39. 
need for education because they understand 'the charms of virtue' and that patriots are made, not by books, but by 'a perpetual sacrifice made to the nation., ${ }^{36}$ The effect of this statement is tremendous. In his history of Babeuf, Buonorotti takes great pains to show how Babeuf was an uneducated peasant who conceived his ideology out of a true understanding of the suffering of the people. Babeuf himself, in this pamphlet, seems to argue the same thing. This argument, however, is ridiculous. Any thorough reading of Babeuf's polemical writings evidences that Babeuf was well educated. Pamphlets like Voyage des jacobins, Les battus payant amende, and On veut sauver Carrier show that Babeuf had a tremendous grasp of classical history. In addition, his systematic use of allusion and metaphor can only be explained by a thorough education.

The reason that Babeuf sought in G. Babeuf/Tribun du Peuple à ses Concitoyens to distance himself from his 'privileged' past as an educated surveyor of noble estates is to establish himself as a member of the artisan-dominated parti des sans-culottes. By February, 1795, Babeuf had alienated himself from the power structures of the Thermidorian regime. Politically isolated by his criticism of the path of the Revolution, Babeuf was astute enough to realize that the only remaining venue of popular support that he could hope to sway was the remnants of the radical and Robespierrist left. Thus, more than a truthful rendering of republican service, $G$. Babeuf / Tribun du Peuple à ses Concitoyens is a tract of politically motivated history.

${ }^{36}$ Ibid., 4. 
Though its initial success was negligible, its effect on the production and furtherance of Babeuf as a prognosticator of social revolution was tremendous.

The Revisionism of Babeuf:

From the Printing Press to the Guillotine

The printing press and the guillotine depict the landscape of both the French Revolution and François-Noël 'Gracchus' Babeuf. For the Revolution, the printing press appeared as the embodiment of freedom. The guillotine, however, assumed the mantle of the most vicious vehicle of la République indivisible. This contradiction between the thesis of universal liberty and the antithesis of conspiracy frames the revolutionary discourse of Babeuf. For Babeuf, the printing press and guillotine define his revolutionary career: he achieved his republican reputation through the printing press and his revolutionary legacy as a victim of the guillotine. As representations of the origins and culmination of his revolutionary career, the printing press and the guillotine evidence the inherent paradoxes in the language of Gracchus Babeuf.

The dynamic of opposing realities, from urban to rural, from radical to moderate, from Thermidorian to Jacobin, and from the printing press to the guillotine, is an essential element within the study of Babeuf. Babeuf was a creation of obvious paradoxes. Born in 1760, and educated as the son as a minor royal official in rural 
France, ${ }^{37}$ Babeuf would attain stature in the urban, cobble-stoned streets of Paris in the 1790s. Committed to fashioning a new France, Babeuf was confined to the historical paradigms of the classical age. While Dale Van Kley argues that 'The French Revolution resolutely set its face towards the future and turned its back on the past-or at least the French past- maintaining rhetorical contact with only the distant classical past, ${ }^{38}$ the discourse of Babeuf evidences a passionate commitment to history. For a supposed harbinger of nineteenth-century rhetoric and revolution, Babeuf was relentlessly historical. In his polemical pamphlets Les battus payant amende, On veut sauver Carrier, and Voyage des jacobins Babeuf reads French history as what Van Kley calls 'an unending series of usurpations of national and constitutional rights by the forces of ministerial despotism. ${ }^{39}$

These polemics are a product of a superficial incongruity. All three pamphlets were published in the months after the fall of Robespierre and the Terror. Each pamphlet, in turn, is a collection of allusions and parables that comment on the historical virtue and ultimate corruption of Maxmilien Robespierre and the Jacobin Club. Though seemingly anti-Jacobinical, these pamphlets evidence a highly advanced

${ }^{37}$ Babeuf's father was salt tax (gabelle) collector. Though later historians like R.B. Rose would attempt to show the humility of Claude Babeuf's occuptaion, he was entitled to wear a sword and considered a member of the privileged orders in the ancien régime.

${ }^{38}$ Dale Van Kley, "New Wine in Old Wineskins: Continuity and Rupture in the Pamphlet Debate of the french Prerevolution, 1787-1789." French Historical Studies, Vol. 17, no. 2, Fall (1991): 448.

${ }^{39}$ Ibid., 451. 
and complex level of criticism against Thermidorian regime. Unable to publish an unequivocal acclamation of the Robespierrist regime in November and December of 1794, Babeuf composes a series of pamphlets that systematically condemn the hypocrisy of the Jacobins turned Thermidorians. Through his denunciation of Fréron, Tallien, and Guffroy, Babeuf produced a vindication of the original philosophical origins of Jacobinism.

Babeuf frames his subtle praise and open criticism of the Jacobins and Robespierre deep within historical and biblical allegories. This motif evidences a highly complex thought process. In Les battus payant amende and Voyage des jacobins, the majority of Babeuf's praise of the Jacobins is placed in the distant past. By placing his acclaim of the Jacobins in an allegory of classical Rome, Babeuf is simultaneously able to allude to the virtue of the society without appearing to advocate a return to the Terror.

It is, however, Babeuf's representation of Robespierre that demonstrates his greatest level of complexity. Babeuf achieves his discourse on Robespierre through a unique blending of Christian doctrine. Through his co-optation both the Book of Acts, Babeuf conceives of Robespierre as a religious icon. What becomes apparent through these pamphlets is a late eighteenth-century usage of the older theological concepts of both the 'King's two bodies' and 'figurism. ${ }^{40}$

${ }^{40}$ Another element that appears in these pamphlets is Babeuf's obvious hatred of indulgence and corruption. These notions, when combined with his co-optation of 
Traditional historiography has reflected neither the philosophical depth nor the re-conversion to Jacobinism evidenced within Babeuf's Thermidorian works.

Historians from Georges Lefebvre to Branislaw Bazcko have dismissed Babeuf's polemical pamphlets of Thermidor as either naive ${ }^{41}$ or confused. ${ }^{42}$ The superficial paradoxes of Babeuf's language and discourse have been presented as evidence of Babeuf's sponsorship of the Thermidorian regime. This tradition has led historians from Albert Soboul to R. B. Rose to view the Thermidorian Babeuf as a member of the anti-Robespierrist camp. As a result, Babeuf's re-conversion to Jacobinism has been historically assigned as a reaction against the Directory.

However, with a thorough reading of Les battus payant amende, On veut sauver Carrier, and Voyage des jacobins another image of Babeuf arises. What becomes obvious within these texts is that 1) the thinking of Babeuf is both complex and paradoxical, 2) that Babeuf's re-conversion to Jacobinism occurred, not in the fall

religious doctrines appears to evidence Babeuf's philosophical ties to Jansenism. The connection between Jansenism and Babeuf has never been researched. It seems obvious through an examination of his Thermidorian pamphlets (Les battus payant amende, On veut sauver Carrier, and Voyage des jacobins) that Babeuf was highly influenced by the Jansenist tradition of Parliamentary opposition. However, on a deeper level, two particular aspects of Babeuf's rhetoric seem to owe their origin to eighteenth-century Jansenist theology: figurism and the King's two bodies (both philosophies are described in greater detail in chapter V and IV, respectively).

${ }^{41}$ See Lefebvre's Les Thermidoriens. Lefebvre argues that Babeuf was penniless and fell prey to the vicious anti-Robespierrist rhetoric of Guffroy.

${ }^{42}$ See Baczko's Ending the Terror: The French Revolution after Robespierre. Bazcko sees the paradox between Babeuf's praise and condemnation of Robespierre and the Jacobins as evidence of a political confusion. 
of 1795 , but in the fall of 1794,3 ) that there exists a continuity of discourse and language during Babeuf's re-conversion to Jacobinism, and 4) that the intricacy of Babeuf's thinking is evidenced in his rendering of a notion of 'duality' between the spiritual and philosophical purity of Robespierre and the Jacobins, and their ultimate physical corruption during the reign of Terror.

By examining three tracts produced during the height of the Thermidorian reaction, between 15 Vendemaire and 14 Pluvois, III, ${ }^{43}$ I will show that the revolutionary career and legacy of Gracchus Babeuf extends beyond the episode of the Conspiracy for Equality. It is the vivid and often violent rhetoric that Babeuf utilizes in his Voyage des jacobins, Les battus payant amende, and On veut sauver Carrier that epitomizes true Babouvist ideology. Furthermore, through an examination of these three tracts, I intend to establish that the condemnation of Babeuf under the Directory in 1797 was a result of neither the advocating of the agrarian law nor the unproved conspiracy for the violent overthrow of the Directorial regime. Rather, the condemnation of Babeuf resulted from his specific and systemic language. Babeuf is the only journalist in the French Revolution to have been guillotined, not like Hébert, for an assumed complicity in conspiratorial actions, but for the radical content of his writings. The execution of Babeuf was undertaken because he used his polemical pamphlets and his journal, Le Tribun du Peuple, to condemn the victors and re-invent

${ }^{43} 8$ October 1794 and 14 February 1795. 
the vanquished of 9 Thermidor. In a very real sense, Babeuf was executed because the government feared that his words and language would foment a new revolution. 
[II]

PRINTED POISON:

Babeuf, the Radical Press and the Language of Denunciation

From Thermidor to the Ancien Régime:

The Language of the Fall of Robespierre

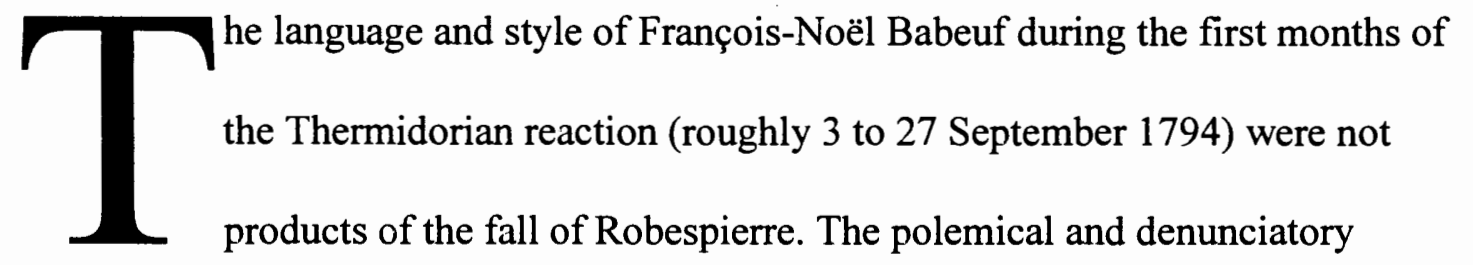

rhetoric of le Journal de la Liberté de la presse was the product of the Revolution as a whole. This analysis of the le Tribun du Peuple and le Journal de la Liberté de la presse is centered on a more general examination of the language from the Terror to the ancien régime. By investigating the journalistic styles from le Père Duchesne to the libelistes of the ancien régime, I will prove a continuity between the radical, revolutionary, and alienated journalists and their criticisms of society.

On 10 Thermidor, Branislaw Bazcko writes, France awoke anti-Robespierrist and even 'Thermidorian." 44 To take sides with the victors was the most elementary

${ }^{44}$ Bronislaw Baczko, Ending the Terror: The French Revolution after Robespierre, trans. Michel Petheran, (Cambridge: Editions de la Maison des Sciences de l'Homme and Cambridge University Press, 1994). 3. 
prudence for the majority of revolutionary journalists. The language of the Fall, then, must be seen in the context of the political reality of the fall and execution of Maxmilien Robespierre.

With the condemnation of Robespierre on 9 Thermidor, France sought to put an end to the most deadly and vicious episode of the French Revolution: the Reign of Terror and Virtue. Under the apparent dictatorial power of the Committee for Public Safety, the guillotine rose as a horrific testament to the insecurity of the revolutionary government. The men of the Committee, Robespierre, Louis-Antione Saint-Just, ${ }^{45}$ Georges Couthon, ${ }^{46}$ Bertrand Barère, ${ }^{47}$ Jean-Nicolas Billaud-Varennes, Jean-Marie Collot d'Herbois, ${ }^{48}$ Lazare Carnot, Marie-Jean Hérault de Séchelles, Robert Lindet, Pierre-Louis Prieur, and André Jeanbon Saint-André assumed executive power over the Revolution on September 5, $1793 .^{49}$ With the disasters of both foreign and civil wars, Robespierre and the Jacobins realized that to save the Revolution required immediate action. The Jacobins suspended the Constitution of 1793 and began to promote several radical domestic measures: the creation of the maximum to stem

${ }^{45}$ The youngest of the twelve. Known as the 'Angel of Death.'

${ }^{46}$ Executed on 10 Thermidor as part of the triumvirate with Robespierre and Saint-Just.

${ }^{47}$ R.R. Palmer refers to Barère as the 'Anacreon of the Gullotine', meaning, it appears, that Barère's eloquence in the justification was poetic.

${ }^{48}$ Both Billaud-Varennes and Herbois would suffer under the Thermidorian regime. Along with Barère and Vadier, the Trail of the Four would become an important episode in the evolution of Babouvist langauge.

${ }^{49}$ R. R. Palmer, The Twelve Who Ruled, (Princeton: University Press, 1969), 44. 
inflation and secure necessary food-stuffs for Paris and the levée en masse to swell the ranks of the Revolutionary Army to protect the Republic.

It can be easily argued that the Terror saved the Republic. By the summer of 1794, France was safe from the imminent perils of both starvation and invasion. Victories in the fields, both military and agricultural, assured the Republic sufficient grain and safety. It is in this victory that the Terror became redefined as oppression. While the Republic suffered under the duel threat of external and internal combat, the suppression and execution of rival voices within the government was acceptable. However, with victory and apparent security, the supremacy of the Committee of Public Safety over the deputies of the National Convention became unacceptable. On 9 Thermidor, during a ferocious debate, the Convention rose against Robespierre and the Committee. With his execution on 10 Thermidor, the Terror and the influence and authority of Maxmilien Robespierre was assumed to be at an end.

After the fall, those who had saved the republic were condemned in body and in memory. Robespierre became cast as a tyrant. The Jacobins became the 'knights of the guillotine.' Responsibility for the Terror was immediately shifted to the 'loathsome tyrant' and separated from the 'events inseparable from a great revolution.' ${ }^{50}$ The virulence of the rhetoric against Robespierre must be seen as the attempt of the remaining revolutionary and republican elements of the government to show that the

${ }^{50}$ Baczko, Ending the Terror, 59. 
tyranny of Robespierre was seen as the exercise of a sole individual's corrupted revolutionary power.

The unanimous condemnation of Robespierre was a catharsis. It was assumed that those members of the Revolutionary government that had supported, profited from the regime or even believed that the Terror had not gone far enough, were to redeem themselves through their violent condemnation of Robespierre. It was assumed that through a vocal denunciation of its excess, that the specter of the Terror would move from the Convention to the executed triumphers: Robespierre. Saint-Just, and Couthon. In this atmosphere, François-Noël Babeuf, at the invitation of the ex-Jacobin deputy and printer A.-B.-J. Guffroy, set pen to paper to compose a violent and seemingly anti-Robespierrist journal.

Despite the relative success of the le Journal de la Liberté de la presse, Babeuf was unable to maintain his political allegiances within the Thermidorian regime. Though he criticized both Robespierre and the Jacobins, Babeuf found himself increasingly at odds with the governance of Revolutionary France. Guffroy had intended the le Journal de la Liberté de la presse to act as a mouthpiece of the victors of 9 Thermidor. Guffroy conceived of Babeuf's journal as a medium to condemn the memory of Robespierre and the existence of the Jacobins while simultaneously supporting the policies of the Thermidorian Convention. As the months passed from July to October, Babeuf came to the realization that the coup of 9 Thermidor had 
succeeded in decapitating both Robespierre and the most popular measures of the Jacobin regime. The numerous popular rights achieved under Robespierre in year II, such as the right to work, to relief, to education, were dismissed by the new power structure of the state. Babeuf saw Thermidor as the end of revolutionary progression and the commencement of a regression to the inequity of the ancien régime.

It is from this moment that Babeuf moved from critic to apologist of the Robespierrist regime. Babeuf became increasingly disenchanted with the Thermidorian regime as he became more acutely aware that the equality reaffirmed by the Thermidorians rested solely within the realm of civic equality. The Thermidorian principle of liberty, far from the lofty ideals of popular sovereignty and direct democracy that justified the coup, was a precarious balance between the twin dangers of revolution: the omnipotence of Parisian popular societies and remnants of the Jacobins. ${ }^{51}$ It is from this instant that Babeuf reinvented his rhetoric and journalistic discourse to oppose the Thermidorian regime and its systematic dismantling of the French Revolution.

${ }^{51}$ Denis Woronoff, The Thermidorian regime and the Directory 1794-1799, Trans Julian Jackson, (Cambridge, New York: Cambridge University Press, 1984), 30 . 


\section{Guffroy, Babeuf, and \\ Le Journal de la Liberté de la presse.}

Armand-Benoit-Joseph Guffroy liberated the language and discourse of François-Noël 'Gracchus' Babeuf. ${ }^{52}$ In a vicious letter, written on 21 Vendemiare, III, Guffroy states clearly the reasons for a rupture in the relationship between the editor and the publisher of the le Journal de la Liberté de la presse. Guffroy writes:

Tu sais que je n'ai point hésité à consacrer mes presses à la conquête de la liberté d'exprimer sa pensée. Ce sentiment sera toujours le mobile de mes actions. En le suivant, je n'ai vu que la patrie. . ${ }^{53}$

Guffroy's consecration of presses, however, is limited in both scope and intent.

Though he states that he thinks 'only of the country', Guffroy's printing house attempted to exert a tremendous influence over the material in Babeuf's le Journal de la Liberté de la presse. It is his commitment to the Revolution that leads Guffroy to criticize Babeuf. Guffroy writes:

Il faut donc que nos médicins politiques sachet ménager le remède et le malade. . . il est trés dangereux qu'un patriote, qu'un Tribun du peuple, tienne le même langage que ses enemies. . il est dangereux pour la consolidation du bonheur public de trouver, à côté des principes les plus purs, le poison de la plus subtile aristocratie .. .Pour arriver à la Convention, les extravagants ont prêché la loi agaire. Les mêmes hommes et ceux du même calibre vont aussi prêcher la loi agraire, ou l'équivalent, pour arriver à la Législature qui viendra maintenir le gouvernment populaire et républicain, quand la Convention l'aura establi sur des bases inébranlables ... Déjà

${ }^{52}$ François-Noël Babeuf assumed the name Gracchus in honor of the tradition of Tiberius and Caius Gracchi with the publication of the first edition of his le Tribun $d u$ Peuple on 14 Vendemiaire. This name change is important as an evidence to the evolution of Babeuf's discourse. It signifies the break with Babeuf's past and the creation of a new republican rhetoric.

${ }^{53}$ Aulard, 'Babeuf et son Imprimeur Guffroy.' 8. 
les bons esprits voient les intrigants dresser leurs échelles pour arriver à cette Assemblée, et si toi, Babeuf, tu ne penses pas comme ces hommes pervers, tu parles pourtant leur langage. Dès lors, nous ne pouvons plus combattre de front. Je ne suis plus ton imprimeur. ${ }^{54}$

In this statement, Guffroy frames his criticism with the most severe of denunciations.

Though Guffroy does not explicitly condemn Babeuf as 'counter-

revolutionary', this letter served to remove Babeuf from the political center of the Thermidorian regime. Guffroy warns Babeuf that his radical journalism has co-opted the disgraced republican language. Guffroy continues that Babeuf has infused his discourse with the 'most subtle aristocratic poison.' Guffroy proclaims that though Babeuf does not think like a wicked man, he has depraved his republican virtue by utilizing the same language as les hommes prevers.

For Guffroy, the power of language is self-evident. Revolutionary language serves as a symbol, as obvious on the printed page as a red cockade is on the head of a patriot. As an attribute, language becomes synonymous with public practice. Language is the outward embodiment of internal politics. As the journalistic language of Babeuf became corrupted, Guffroy responded that this linguistic degradation would destroy Babeuf the patriot. Guffroy's final remark that 'I am no longer your printer' can thus be seen as both a threat to the journalist and a warning to the patriot. What is implicit in this correspondence, in the denunciatory language utilized by Guffroy, is the

${ }^{54}$ Ibid. 
anathamization of Babeuf by the Thermidorians. Babeuf's opinion, as shown through his language, has exceeded the tolerance of the regime.

Even more dangerous is Guffroy's alignment of le Tribun du Peuple with the great, and relatively unrealistic anxiety of the agrarian law. The fear that radical republican revolutionaries intended to seize private property and redistribute it to the poor and landless became an icon of moderate and counter-revolutionary concern. Babeuf, though not advocating either the destruction or the radical redistribution of land, was to be branded in 1794 as a loi agrairiste by Guffroy. ${ }^{55}$

According to Alphonse Aulard, A.-B.-J. Guffroy is poorly qualified to give advice on journalistic moderation and prudence. Guffroy had himself been expelled from the Jacobin club, on 11 Ventôse, year II, for his violent rhetoric as a journalist. On that day, Guffroy was cited by the tribun of the club for his violent outburst of:

\footnotetext{
Abattons tous les nobles, et tant pis pour les bons, s'il y en a. Que la guillotine soit en permanence dans toute la République. La France a assez de cinq million d'habitants! ' $^{56}$
}

${ }^{55}$ For an explation of the Agrarian Law, see: P.M. Jones, "Land redistribution during the French Revolution." Past and Present, no. 133 (November 1991), pp. 96133. Jones states that the occurrence of land redistribution during the Revolution was both more common and important than historians have generally argued. Specifically, Jones counters the arguments of R. B. Rose, "The 'Red Scare' of the 1790s: The French Revolution and the Agrarian Law," Past and Present, no. 103 (May 1984), pp.113-30.

${ }^{56}$ Aulard, 'Babeuf et son Imprimeur Guffroy.': 19. 
A minor official from Arras, Guffroy had been given an appointment on the Committee of General Security under Robespierre. In 1794, however, his commission came to an abrupt end when Guffroy undertook the authorship and publication of a journal called le Rougyff: ou la France en vendette. ${ }^{57}$

Le Rougyff was, in the winter of 1794 , one of the most violent terrorist journals. ${ }^{58}$ Guffroy founded his paper soon after the death of Jean-Paul Marat in July of 1793. From the start, Guffroy assumed and perfected, along with le Père Duchesne of Hébert, the violent rhetoric of the Jacobinical press of year II. On 1 October 1793, Guffroy writes:

\begin{abstract}
Allons vite, Convention! Alerte, montagnards! Alerte, mes braves bougres! Foutezmoi la chasse à tous les généraux perfides, à tous les généraux lâches, à tous les généraux avides, à tous les générraux uniquement amoureux de la gloire des combats, à tous les états-majors ignorants, luxurieux, débauchés, à tous les commissaires jeanfoutres. ${ }^{59}$
\end{abstract}

Like other Jacobin sheets of the Terror, Guffroy's language is simple, direct, and impassioned with denunciation. Guffroy utilizes strong phrases and words like 'treachery,' 'debauchery,' and 'luxury' to create a specific and corporeal reaction within the reader. Guffroy's le Rougyff is not a news-sheet intended to educate. It is, rather, a polemic conceived to enflame and fan the fires of revolutionary passion. On 12 Frimaire, year II, Guffroy writes:

${ }^{57}$ Dictionnaire de biographie française, Tome 17, ed M. Prévost and R. D'Amant, (Paris, Libarie Letouzet et Ané, 1981), 35.

${ }^{58}$ Aulard, 'Babeuf et son Imprimeur Guffroy.': 20.

${ }^{59}$ Ibid. 
S'il est beau pour un philosophe de voir danser la carmagnole à tous les saints de France, s'il est doux de voir sainte Thérèse danser un menuet avec le diable de saintMichel, le politique philosophe doit prendre des mesures pour que cet événement inattendu n'altère pas le mouvement révolutionare et ne nuise à l'affermissement de la République. ${ }^{60}$

In his journal, Guffroy celebrated all the executions. Regardless of the proximity of rhetoric, Guffroy applauded the guillotining of Hébert. He writes on 9 Floréal:

Français, silence dans les rangs, attention au commandement, silence! La virtu et la franternité ont mis au pas toute la république, et la terreur n'existe que pour le crime. $^{61}$

Initially, the violent language of Guffroy served the revolutionary purposes of Robespierre. However, like Hébert, Guffroy did not reserve his journalistic criticism for the counter-revolution. As the Jacobin dictatorship extended its power and authority over the Convention, Guffroy unleashed a vitriolic attack against the revolutionary government. Guffroy's harsh criticism of Robespierre's dominance over the Committee for Public Safety in le Rougyff resulted in Guffroy's condemnation before the National Convention.

Guffroy was accused of keeping relations with émigrés ${ }^{62}$ and royalists. He was thrown out of the Jacobin society, and at the insistence of Robespierre, was

${ }^{60}$ Ibid.,: 21.

${ }^{61}$ Ibid.,: 22.

${ }^{62}$ The émigrés were the portion of the French privileged classes that had fled over the border of France to Germany and England with the outbreak of the Revolution. Throughtout the Revolution, the fear that émigrés were conspiring with William Pitt and the crowned heads of Europe to overthrow the revolutionary government and re-instate the King and noble classes was omnipresent. The assumption of association with the émigrés was counter-revolutionary and a common excuse for execution. 
removed from all posts within the government. In a statement of supreme irony, the Abbé Chasles chastised Guffroy's journal in the same language that Guffroy would unleash against Babeuf in the fall of 1794. In a statement that could easily have won Guffroy a trip to the scaffold, Chasles characterized le Rougyff as being 'infecté du poison le plus aristocratique. ${ }^{63}$

Guffroy's vindication came on 9 Thermidor when Robespierre was denounced as a tyrant before the Convention. Under the Thermidorian regime, Guffroy was charged with the inventory of Maxmilien Robespierre's papers. It was among these papers that Guffroy 'discovered' the list of citizens and deputies that were to be condemned to the guillotine. ${ }^{64}$ Guffroy seized this discovery with political vengeance. From the fall of Robespierre, the career of Guffroy was to be centered exclusively on the aim to discredit and malign both the executed leaders and remnants of the Mountain. ${ }^{65}$

Biographers have grappled with the professional connection between Babeuf and Thermidorians like Guffroy. The most problematic aspect of this association lies in the fact that Guffroy was a publisher whose pamphlets epitomized the Thermidorian and anti-Robespierrist reaction. It is impossible to disassociate the initial Thermidorian

${ }^{63}$ Dictionnaire de biographie française, 35 .

${ }^{64}$ Robespierre's list, as it came to called, provided an excuse and justification for the National Convention to declare its authority and historic opposition to the Terror. The list and its effect on Babeuf are discussed in greater detail in chapter III. ${ }^{65}$ Ibid. 
writings of Babeuf from the infamous conspirators and profiteers of 9 Thermidor. Babeuf's le Journal de la Liberté de la presse is filled with quotations from Fréron. Babeuf's journal also included a citation from the deputy Tallien (whose mission to Bordeaux Robespierre had condemned as the debasement of the Terror). In the postRobespierre political landscape, both Fréron and Tallien were to assume the role of the 'weathervane.' As Thermidor progressed, these men would become the objects of Babeuf's derision. Babeuf would condemn Fréron and Tallien as political turncoats whose actions were taken from neither strong morals nor convictions, but from political expedience. They were men who, according to Bronislaw Bazcko, would personify the figure of the shifty Thermidorian politician. ${ }^{66}$

The irony of Babeuf's early discourse is that while he chastises Robespierre and the Jacobin minority for dismantling the freedoms that were won in 1789 , he simultaneously and naively sees the Thermidorians as the vehicle for the recreation of a democratic state. ${ }^{67}$ It is this disparity between the writings of 1794 and those of 1796 that has drawn great criticism, but little in-depth research. Historians who have studied the works of Babeuf, from Aulard to Fehér, have almost unanimously decried the political affiliation le Journal de la Liberté de la presse without seeking to reconstitute the specific political climate of Thermidor. Mathiez, despite his insistence that Babeuf was a Robespierrist, dismisses this work as being one of the journals that

${ }^{66}$ Baczko, Ending the Terror, 49.

${ }^{67}$ Rose, Gracchus Babeuf, 158. 
rallied the Jeunesse dorée ${ }^{68}$ against the remnants of the Jacobin regime. Kåre Tønnesson, while conceding Babeuf's 'good faith,' similarly argued that the effect of Babeuf's journals was to 'contribute to the success of the bourgeois reaction' against the sans-culottes. ${ }^{69}$

Babeuf did play a significant role within the reactionary press. Supported by Tallien, and inspired by Fréron's Orateur du Peuple, Babeuf's discourse in le Journal de la Liberté de la presse was heterogeneous in its open and copious condemnation of the Robespierrist regime. Babeuf's connection with Fréron and the other Thermidorian conspirators lies with A.-J.-B. Guffroy. It was Guffroy who published the reactionary Orateur du Peuple of Fréron (whom Albert Mathiez referred to as 'the debauched who had shed torrents of blood at Toulon and Marseilles.'). ${ }^{70}$ Guffroy was also responsible for the publication of one of the most infamous anti-Jacobin pamphlets : La Queue de Robespierre. Guffroy's publications were the type of violent printed poison whose attacks on the Jacobin remnants of the Convention would lead

${ }^{68}$ Known as the 'guilded youth,' these draft dodgers filled the ranks of the moderate and conservative reaction against the Jacobins and the sans-culottes. They were physically discernable by their black collars and white wigs. Their presence in post-Terror Paris was a testament to the relaxation of the strict and oppressive moral climate under Robespierre. 1959), 62.

${ }^{69}$ Kåre Tønnesson, La Défaite des sans-culottes, (Paris: Librairie R. Clavreuil,

${ }^{70}$ Albert Mathiez, After Robespierre: The Thermidorian Reaction, trans. Catherine Alison Phillips, (New York: Grosset \& Dunlap, the Universal Library, 1965), 11. 
ultimately to the trial of Carrier, Billaud-Varnennes, Barère and several other Montagnard orchestrators of the coup of 9 Thermidor.

Guffroy had become the publisher of the le Journal de la Liberté de la presse on 3 September 1794. Though it has proven for his biographers to be the most problematic episode of his political career, the month long association with Guffroy was the solitary journalistic success of François-Noël Babeuf. The first numbers of le Journal de la Liberté de la presse ran into two editions, there were eight hundred subscribers (each of whom paid four livres), and the average printing was twelve hundred copies per issue. ${ }^{71}$ In this respect, Babeuf's le Journal de la Liberté de la presse must be placed, as Mathiez concedes, in the reactionary camp of Thermidor. The style and language of the journal clearly show that Babeuf violently attacked 'the establishment of the Jacobin revolutionary government' as both counter-revolutionary and anti-democratic.

However, as the Thermidorian reaction continued, the criticism that Babeuf held for Robespierre was not that the Terror was unjust, or even that innocent citizens were deprived of life and livelihood, but rather that Robespierre had betrayed the revolution after the execution of the king. Babeuf sought, in the le Journal de la Liberté de la presse, to explain how Robespierre had failed to achieve what Babeuf believed was the ultimate goal of the Revolution: the destruction of social inequity.

${ }^{71}$ Rose, Gracchus Babeuf, 157. 
The ultimate result of this justification was the movement, by issue twenty-one of the le Journal de la Liberté de la presse, from a safe position of criticism of the Terror to an attack on the legitimacy of the Convention. With the publication of $n^{\circ} 21$, the language of Babeuf moved to an open offensive in which he declared that the revolutionary government had betrayed the rights of the people. Babeuf denounced the decision of the Convention to suppress the section assemblies of Paris. Guffroy, in turn, denounced Babeuf as counter-revolutionary and severed all professional ties with the editor of le Journal de la Liberté de la presse.

There is a certain subtlety to the language of Babeuf's early Thermidorian works. In one of the most interesting manifestations of Babeuf's revolutionary language, Babeuf established in issue $\mathrm{n}^{\circ} 1$ of the le Journal de la Liberté de la presse a notion of duality that would permeate the whole of his Thermidorian discourse. ${ }^{72}$ Babeuf writes:

For example, if the memory of Robespierre is justifiably abhorred today, it is necessary to distinguish between persons, that is to say, Robespierre the sincere patriot and friend of the principles commenced in 1793, and Robespierre the ambitious and greatest tyrant of this epoch ... ${ }^{73}$

${ }^{72}$ This notion of daulity has been researched in great depth by Ernst Kantorowicz's The King's Two Bodies, (Princeton, University Press, 1957). Dale Van Kley, in his recent publication, The Religious Origins of the French Revolution, (Yale, University Press, 1996) argues that this philosophy re-emerged in the eighteenth century as Jansensist figurism.

${ }^{73}$ F.-N. Babeuf, le Le Le Journal de la Liberté de la presse, $\mathrm{n}^{\circ}$ 1, (Paris: Guffroy, 1794), 1 
Writing on a similar theme on 8 October, Babeuf emphasized that the revolutionary government of the Jacobins could no longer be explained as a 'bloody aberration of Robespierre. ${ }^{74}$ Instead, he argues, it must be seen as a device that was controlled by a specific grouping of revolutionaries who manipulated the system and its authority. The Jacobin legislators, Babeuf writes, 'instead of concerning themselves with the general good' busied themselves with their own 'particular interest.' ${ }^{75}$ Babeuf establishes two distinct Jacobins within this tract: the pure and the corrupt.

While Babeuf's $n^{\circ} 21$ can be read as a critique of the remnants of the Jacobin regime, it contains a deeper condemnation of the Thermidorian reaction. Latent within his anti-Jacobin rhetoric is a plea for the Thermidorian regime to re-institute the democracy lost by Robespierre. This change in tactic and perspective signifies the move by Babeuf from the Thermidorian camp to that of an anti-Convention critic. This evolution also evidences a deeper and more profound level of criticism than has been historically attributed to Babeuf during Thermidor. Babeuf's pen would now take to paper to discredit not only the elitism of the Jacobins, but also the hypocrites of Thermidor who decried the tyranny of Robespierre while maintaining his system.

The next three issues of le Journal de la Liberté de la presse, published 10, 14, and 16 Vendemaîre launched a full attack on the character of Fréron. Babeuf writes

${ }^{74}$ Rose, Gracchus Babeuf, 160.

${ }^{75}$ F.-N. Babeuf, Le Le Journal de la Liberté de la presse, $\mathrm{n}^{\circ} 21$, (Paris: Guffroy, 1794), 21. 
that Fréron and his fellow conspirators had relied on denunciation, revolt, and violence only to cover up their lack of principle. Babeuf expresses through le Journal de la Liberté de la presse that he and his fellow democrats had been victims of the Thermidorian regime. 'Tyranny,' Babeuf writes, 'is on the point of gaining a complete triumph and overthrowing forever the republican system. ${ }^{76}$

It was this open attack on the terrorists turned Thermidorians that prompted the breach with Guffroy. As Babeuf's publisher, Guffroy had sought to use Babeuf's le Journal de la Liberté de la presse as an open attack on Robespierre and the Jacobins. The violent anti-Jacobinical rhetoric found in the early edition of Babeuf's journal appears to be more a product of the agenda of Guffroy than the reasoned opinion of Babeuf. When the fervor of Babeuf was unleashed upon Fréron, the sponsorship of le Journal de la Liberté de la presse was suddenly embarrassing to the Thermidorian power structure.

Historians have commented that consistent within twenty of the twenty-one issues of Babeuf's le Journal de la Liberté de la presse, published by Guffroy, is a strict and unequivocal condemnation of Robespierre. However, as shown above, Babeuf initiates in the first of his editions a notion of duality that justifies both his condemnation and praise of Robespierre. Babeuf establishes with $\mathrm{n}^{\circ} 1$ of le Journal de la Liberté de la presse the distinction between Robespierre the tyrant and Robespierre

${ }^{76}$ Babeuf, Le Le Journal de la Liberté de la presse, $\mathrm{n}^{\circ} 21,34$. 
the patriot. Within the linguistic discourse of Babeuf, these two entities are totally dissimilar. Robespierre the Patriot exists beyond the corrupted and guillotined Robespierre the Tyrant.

In a metaphysical justification that grew directly from the arguments of the medieval French monarchy, ${ }^{77}$ Babeuf argues that, like the Bourbon kings, Robespierre has two bodies. Though initially veiled in the acceptable language of the early Thermidorian reaction, Babeuf, as early as September 1794, advocates by a delineated usage of Robespierre the Tyrant versus Maxmilien the Patriot. In $n^{\circ} 1$ of $l e$ Tribun du Peuple, Babeuf states:

We will esteem and admire the work (Declaration of Rights of Man) and we will not forget he who was a worker, a sincere patriot and friend of principles up to the beginning of 1793 , but since that time a most arrant villain. ${ }^{78}$

Two of Babeuf's Thermidorian polemics, Les battus payant amende and Voyage des jacobins, make explicit use of this duality to argue that the tyranny of Robespierre was a physical aberration of Maxmilien's spiritual purity. By mid-Fall, the evolution of Babeuf's discourse of Robespierre had achieved a level that was completely incompatible with the Thermidorian reaction.

${ }^{77}$ See Kantorowicz: The King's Two Bodies.

${ }^{78}$ F.-N. Babeuf, Le Le Journal de la Liberté de la presse, No 1,(Paris: de Guffroy, rue Honoré, no 35 (Capucins), 17 Fructidor, II), 2 
The Radical Press and it Suppression under the Mountain

The careful wording of Babeuf's Thermidorian pamphlets points towards a precedent found in the Jacobin dictatorship. The praise that Babeuf gives to Robespierre and the Montagnards is placed specifically within a linguistic context that remains vague. It is obvious that Babeuf is only capable of praising a metaphysical ideal of Robespierre. This distilled conformity, Jean-Paul Bertaud argues, was a product of the power and of the universality of Jacobin authority during 1793 and 1794 . Any criticism of either the regime or the Revolution was forced, Bertaud argues, to be conducted 'sous le couvert d'un prudent conformisme'. ${ }^{79}$ Bertaud argues that to survive the threat of the guillotine journals made use of specific and systematic phraseology of violence. This construct both attacked aristocrats and paid homage to the l'homme social of the sansculottes. ${ }^{80}$ It is for this reason that the greater portion of historians of print give a 'catastrophic image' to the Parisian press under the revolutionary dictatorship of the Jacobins. Historically, this era has been seen as a time in which the "public opinion of 1789' became replaced with an 'espirit public dirgé de main de maitre par les Jacobins. ${ }^{81}$

${ }^{79}$ Jean-Paul Bertaud, "La Presse en 1'an II: Aperçu des recherches en cours." Annales Historiques de la Révolution Française, $\mathrm{N}^{\circ} 2$ (1995): 163.

$$
\begin{aligned}
& { }^{80} \text { Ibid.,: } 164 . \\
& { }^{81} \text { Ibid.,: } 161 .
\end{aligned}
$$


The politics of press followed by the Montagnards was based on the simple notion of eradicating the spirits and the ideology of the ancien régime. The press, as the fourth political power to be controlled, was to act to preserve the unity of the revolutionary cause against the aristocracy. The ideal creation of this policy would be a press driven by a submission to the general will of the people as it was 'manifested in the popular policies of the Jacobin regime. ${ }^{82}$ The reality of this situation was, however, considerably different. Though the journalistic language of this era was a discourse of superficial Jacobin Republicanism, the internal structure of sheets like le Rougyff and le Père Duchesne evidences both a remarkable independence and a subtle satire of the Jacobin regime.

While the consolidation of the Jacobin authority over the National Convention on 2 June 1793 had ostensibly silenced the press of the right, republican journalists found new opportunity. Government subsidization of journals achieved two significant goals. First, republican journals like le Père Duchesne and le Journal de la Montagne attained greater distribution and readership. Secondly, with the growth of a steady governmental control over the means of publication, the Jacobins proliferated their specific language of republicanism. The Jacobin regime had come to power with a lexicon of certain phrases that journalists were encouraged to utilize. Guffroy, in the early editions of his le Rougyff epitomizes this linguistic usage:

Le républicain, l'homme social, ne connaît pas le moi. Toutes ses actions ont pour but la prospérité publique, dans laquelle il trouve ces jouissances individuelles que lui

${ }^{82}$ Ibid.,: 162. 
donnent la franternité et cette communicabilité d'âme qui fait le charme de la vie. Pour obtenir ce bonheur, que faut-il? Force, force, force. Force pour faire justice de tous les ennemies de l'intérieur; force, pour exterminer les satellites des vils suppôts des rois; force, pour oser immoler à la vertu et à la justice nos passions et nos vices. ${ }^{83}$

This passage from le Rougyff is important for one distinct reason: it shows plainly the universality of Jacobin language. Guffroy utilizes words such as bonheur, fraternité, and prospérité public as justifications and embodiments of policies of the Revolutionary Government. However, in this generalized rhetoric of revolutionary purpose is the extremism of discourse that would win both Guffroy and Hébert the scorn of Robespierre.

Guffroy and Hébert can be read as showing the deceptiveness and radicalization of acceptable linguistic constructs. Though Guffroy won Robespierre's censure for his extremism in le Rougyff, it is le Père Duchesne that serves as the embodiment of this journalistic style.

Though relatively moderate in 1790 , by 1791 Hébert had swung fully to the left. In support of the Terror, Hébert's le Père Duchesne announced that France's external enemies were 'less dangerous than the moderate factions at home. ${ }^{84}$ Hébert castigated the moderate opposition to radical democratic revolution. Supported and subsidized by the Jacobin Club, the range of attack from Hébert's pen fell from the

${ }^{83}$ Aulard 'Babeuf et son Imprimeur Guffroy.': 21.

${ }^{84}$ Jeremy Popkin, Revolutionary News: The Press in France, 1789-1799, (Durham and London: Duke University Press, 1990), 162. 
constitutional-monarchist Feuillants in 1791 to the Girondins in 1792 and 1793. In June of 1793 , Hébert writes in victory, and with:

grande joie ... the great revolution ... just laid low the infamous clique of Brissotins and Girondins, who are going to siffler la linotte (Hébertese for imprisonment). ${ }^{85}$

With the elimination of moderate factions from the Convention by the June Days, ${ }^{86}$ Hébert and le Père Duchesne assumed a more politically powerful role within the Jacobin regime. Popkin writes that "the le Père Duchesne, who had always been the fictional embodiment of the common people, now claimed to be the advocate of a government that would devote itself to their interests. ${ }^{87}$ Hébert and his paper openly supported the Jacobin constitution, the anti-clerical campaign, and the abolition of slavery.

The formula of le Père Duchesne was invented at the beginning of the revolutionary decade. It enjoyed its greatest moments at the height of the stormy years of 1792-94. The pamphlet was, Jeremy Popkin writes, a 'boulevard-theater' of 'artful creations, sophisticated enough to comment ironically on their own artifices. ${ }^{88}$ Its quotidian language was a form of journalism that was not readily, in 1792, associated solely with political radicalism. Its political messages, inlaid with a popular humor,

${ }^{85}$ Ibid., 163.

${ }^{86}$ Starting on May 31, 1792, the sections of Paris and the sans-culottes marched on the Convention to demand certain popular measures. Robespierre and the Jacobins seized the initiative to have the moderate faction of the Gironde, led by Brissot and Roland, expelled from the Convention.

${ }^{87}$ Popkin, Revolutionary News, 163.

${ }^{88}$ Ibid., 157. 
created a unique form of entertainment. The linguistic particularities of le Père Duchesne transcended the oaths and declarations of the typical Jacobinical pamphlets while presenting a unified argument in support of the sans-culottes. Hébert's neologisms were centered on a linguistic imagery and description of the guillotine. ${ }^{89}$ Hébert writes of:

the greatest of all joys of the Père Duchesne, after having seen with his own eyes the head of the veto female (Marie-Antionette) separated from her foutu crane's neck. ${ }^{90}$

Hébert was equally vicious in his rendering of the execution of the Girondin deputies. He accused them of cowardice in the presence of the guillotine. Though Revolutionary France had introduced the guillotine as a more humane form of execution, Hébert lauded the humiliation and cruelty that the dread machine imposed on its victims. His rendering of the grotesque death of counter-revolutionaries melded well with the mentality of the common Parisian who flocked to execution as a form of perverse entertainment in justice.

The policies of Robespierre, it seemed in 1793, had found an ally in the pen of Hébert. Hébert, like Babeuf several years later, was quick to discover that the language of opposition is deadly. His colorful writing and virulent attacks catapulted Hébert to both the heights of popularity among the sans-culottes and the fringe of Jacobincal journalistic acceptability.

\footnotetext{
${ }^{89}$ Ibid., 160.

${ }^{90}$ Ibid., 163.
} 
In their zeal to eliminate all visible evidence of division within the people, Robespierre and the Montagnards sought to impose an abstract and universal public language. Le Père Duchesne had created a 'convincing image of the common man',91 and the people's intervention in politics. Unlike the 'high-flown speeches' of Robespierre and Saint-Just, the small crudely printed pamphlets succeeded in putting revolutionary gospel into a language understandable, appreciable, and invariable to the whole of the Peuple.

This language aggravated the precarious balance of cooperation between the divergent factions of the radical party. The Jacobins' discourse of a universal and republican journalism could not exist with this open political factionalism. Open contest within the republic, whether on the Convention floor, in the street, or in the sheets of the news, had to be stified. To do this, however, required that the Jacobin dictatorship re-impose a form of executive censorship that would act as a retrogradation of the Revolution itself. The political justification for the suppression of le Père Duchesne would be voiced after the death of Hébert. Payan and Fourcade, reporting to the commission de l'instruction publique in the summer of 1794, said:

Newspapers are like theaters: they have a moral impact. For this reason they must be placed under some kind of control. What shape should this control take? That is an extremely delicate and important question, which relates to the very principles of freedom, and can therefore only be answered within the context of the principles of the revolutionary government, and the supreme law of the safety of the people ... To publish and comment on legislation is immeasurably influential and dangerous under the regime of a revolutionary government, and where does the power to do such a thing come from? It is something given to a journalist by the nation, or acquired through their own ability? How can public opinion belong to such small men? It is
${ }^{91}$ Ibid., 164. 
time that the law caught hold of a class of counter-revolutionaries that it has so far left untouched. ${ }^{92}$

Freedom of the press, though guaranteed by the constitution, had to be suspended until peace and security had been re-established within the Republic. Thus, the reaction against Hébert was justified as a security measure to save the Republic. Hébert had corrupted his role as a journalist by fashioning himself a radical voice of le Peuple.

Hébert ended under the guillotine because he employed his le Père Duchesne in a campaign against Robespierre and Committee of Public Safety. The journalistic blood-lust that had both captivated the audience and epitomized le Père Duchesne, Popkin asserts, was to have its risks: Hébert's own execution was said to have drawn 'the greatest crowd ever to witness such a spectacle. 93

${ }^{92}$ Hugh Gough, The Newspaper Press in the French Revolution, (Chicago: Dorsey Press, 1988), 109.

${ }^{93}$ Popkin, Revolutionary News, 164. 


\section{The Language of Denunciation from the}

Terror to the Ancien Régime.

It was a Hébertiste radicalization of political language that severed the professional relationship of Babeuf and Guffroy. In the letter of disassociation written to Babeuf, Guffroy states that if the course of criticism chosen by Babeuf continues, the Thermidorian political climate would seek to destroy his works and discredit him as a revolutionary. Just as Robespierre had sought to distance his regime from the radical rambling of Guffroy and Hébert, Guffroy threatened Babeuf with censure and condemnation:

Crois que les méchants, masqués avec quelques pages de la Déclaration des Droits, et plusieurs qui ont lu ton numéro 26 y ont aperçu le dessin. . Quant à moi, je vois, dans ceux qui se donnent cette qualification exclusive, des intentions aussi coupables que celle de ces hommes qui, sous le titre de Jacobins, de Montagnards, ont eu l'impudeur et la perfide de faire signer qu'ils étaient les seuls hommes qui voulussent la République et l'égalité des droits. . . quand on verra que tu insinues que la Convention saura bien empecher le retour de la paix; quand on verra que tu accuses la Convention d'en imposer à une nation éclairée par des finesses. Oui, on croira que tu as ce dessin pervers, quand on verra que tu abuses de quelques phrases exaltées ou insignificantes de certaines addresses bien intentionnées pour avilir le peuple et la Convention, en faissant tenir au peuple et à cette dernière un langage de maitre à des esclaves muselés. . . Car jamais les contre-revolutionaires ne diront au peuple les vrais motifs qui les engagent à agiter les citoyens. J'ajoute que la consequence que tu affectes de tirer de cette donnée ne me paraît pas de bonne foi. ${ }^{94}$

What is striking about the wording of both Guffroy and Hébert is that the discourse distilled by both men, the language of denunciation, bears so many resemblances to the rhetoric of the early revolution. Both Guffroy and Hébert draw their foundation,

${ }^{94}$ Aulard, 'Babeuf et son Imprimeur Guffroy.': 8-9. 
their style, and their linguistic presentation from the language of denunciation found in the libels of the ancien régime.

With the destruction of the ancien régime and its codes of censorship and privilege, Paris was inundated with an outpouring of journalistic endeavors. By 1793 , however, and under the reign of the Mountain, several dozen of these newspapers were eliminated, many editors had been either guillotined or imprisoned. ${ }^{95}$ This executive censorship was not uncommon in France. The famed Republic of Letters was founded in a nation whose laws on the publication and distribution of printed material were both stringent and broad. Thus, from 1788 to 1791 , as the power of the guilds and royal censorship waned, France was submerged in a torrent of pamphlets, books and treatises which, like Babeuf's le Cadastre Perpetuel, placed on their covers the words 'published in 1789 , first year of liberty.'

The fall of the old regime did not create a new occupation composed of writers. There was a significant literary foundation laid in the apartments and the streets of Paris in the years before the fall of the Bastille. The Republic of Letters was a time in which salons grew to unprecedented popularity. These privileged literary sanctuaries were, however, not the only venue for the distribution of ideas. As a mirror to the salon-culture, the cafe culture arose in Paris as a less exclusive precedent of the popular societies. Abandoned by the Philosophes to the bas-littérateurs, the cafe

${ }^{95}$ Gough, The Newspaper Press in the French Revolution, 109. 
functioned 'as the antithesis to the salon.' ${ }^{96}$ The doors of the cafe were open without need of invitation, Robert Darnton argues in his Literary Underground of the Old Régime, and existed only steps from the street. The cafe culture was filled with men who had responded to the call of the Republic of Letters. The promise of the literary life of the second half of the eighteenth century had caused many talented, albeit unconnected, writers to flock to the literary center of the ancien régime 'only to smolder helplessly and expire down and out in Paris., 97

One of the significant results of this emigration to Paris was the creation of a whole under-class of literate, alienated, and angry people. Having discovered no opportunity or acceptance within literary circles of Paris, young men like Jean-Paul Marat set pen to paper with violent condemnation.

The successful and established writer d'Alembert castigated 'this horde of literary rebels' for venting their frustrated ambitions on the académie and the successful writers known as le monde. ${ }^{98}$ The Grub Street writers, however, proclaimed that they had every reason for unleashing their torrents of libels. Young, unconnected writers could not find the compensation in the same way as established philosophes. The newly arrived pens found that the generous pensions available to writers were given primarily to the older, richer, and established writers. While young

${ }^{96}$ Robert Darnton, The Literary Underground of the Old Régime, (Cambridge Mass and London: Harvard University Press, 1982), 23.

${ }^{97}$ Ibid., 13.

${ }^{98}$ Ibid., 18. 
and struggling authors begged the government for support, the government increasingly reserved its coffers for the safe, predictable, and known composers. What these would be philosophes discovered upon their entrance to Paris, was that the marveled republic, like nearly every other convention of old regime, was a 'labyrinth of baroque institutions' that required more than talent to achieve success. ${ }^{99}$

The Occupations of Revolutionary Journalists

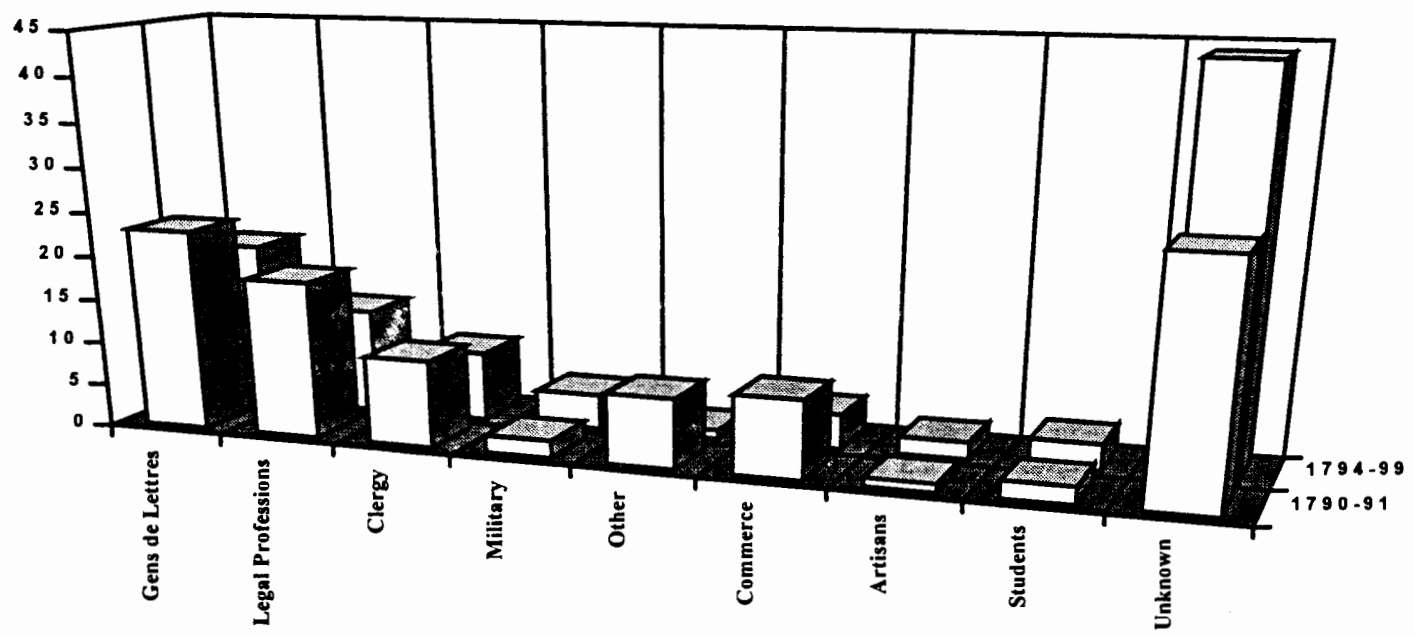

Jeremy Popkin, Revolutionary News, 45.

As the chart from Jeremy Popkin's Revolutionary Press shows, the occupations of revolutionary journalists were not varied. Despite the breakdown of guilds and privilege, the majority of writers came from the legal or literary sections of

${ }^{99}$ Ibid., 22. 
society. ${ }^{100}$ This stratification of journalists shows that despite the rhetoric of an open press, the printed words of revolutionary Paris still echoed from elite pens.

The established literary circle refused to accept the talent, voice, and criticism of these young writers. A significant divide arose between Grub Street 'hacks' and the enlightened writers of the salons. As consummate outsiders, men like Marat used their talent and language to question, critique, and challenge the validity of the institutions of the ancien régime. Rather than challenge the social order, men like d'Alembert and the privileged writers of le monde offered their pens and opinion to prop it up. Rather then dispute the baroque nature of France, both Voltaire and d'Alembert urged writers of proper talent to profit from the mobility available to them in order to join the elite. ${ }^{101}$

Grub Street writers were not nobles and clergymen who enjoyed enough leisure and wealth as to write 'only when the muses struck.' Darnton argues that to these new men of letters, writing was a métier. It is this necessity to depend on a salary, to forge a life from the ink of a pen that prompted Voltaire to castigate these writers as 'the miserable species that writes for a living.' ${ }^{102}$ The only manner of employment available to these writers, these 'ragged rabble' was employment in illegal publishing and the production of libels and pamphlets. ${ }^{103}$

$$
\begin{aligned}
& { }^{100} \text { Ibid. } \\
& { }^{101} \text { Ibid., } 14 . \\
& { }^{102} \text { Ibid., } 17 . \\
& { }^{103} \text { Ibid., } 118 .
\end{aligned}
$$


What happened to this 'the riff-raff of literature (canaille de la littérature)' is that they became the cultural pariahs of the late eighteenth century. Calonne writes that:

Paris is full of young men who take a little facility to be talent, of clerks, accountants, lawyers, soldiers who make themselves into authors, die of hunger, even beg and turn out pamphlets. ${ }^{104}$

Louis-Sebastién Mercier also noted that there were 'famished scribblers, poor hacks (écrivailleurs affamés, ces pauvre barbouilleurs)' found everywhere in Paris.

However, unlike other more established writers, Mercier defended the Grub Street writers from the attack of Voltaire. Though he writes that 'Egypt had fewer locusts,' Mercier tempered his criticism with both qualification and faint praise. Mercier writes that he attacked Grub Street not to chastise the writers, but to warn idealistic youth away from it. For Mercier, the creation of literature does not seem to require either leisure or splendor. In a statement of exceptional equity, Mercier writes that the poor literature of Faubourg Saint-Germian had 'more talent and integrity than the high literature of Faubourg Saint-Honoré.' 105

Through poverty, humiliation, and alienation from the social orders of the ancien régime, these 'dregs of humanity' would produce the Jacobinical version of Rousseau. ${ }^{106}$ The Grub Street writers who would pen the justification of Jacobinism

$$
\begin{aligned}
& { }^{104} \text { Ibid., } 17 . \\
& { }^{105} \text { Ibid., } 18 . \\
& { }^{106} \text { Ibid., } 40 .
\end{aligned}
$$


and Revolution were the product of a common ailment suffered in many of the developing countries during the eighteenth century; the surplus of overeducated and under-employed littérateurs and lawyers. ${ }^{107}$

The only venue for these talents was the creation of popular works that could be produced quickly, easily, and without great capitol expense. The medium became the pamphlet. It was Thiébault who writes, in Mémorire sur la liberté de la presse, as a warning that:

It should be noted that ill educated people, who need money and have no other means of supporting themselves, will quickly turn their hands to these unfortunate enterprises; and that the inevitable failure of most of them will result in huge losses for those who provided the finance, for others who were unwise enough to take part, and especially for the regrettably large number of their subscribers. ${ }^{108}$

Having entered Grub Street, the writer was marked. Once stigmatized by the connection to the bas-litterateurs, the writer could no longer penetrate polite society. The reaction of the peripheral writers was to curse the whole establishment. ${ }^{109}$ The pre-Revolutionary works of Marat do not express a mere and vague anti-establishment bias. Rather, their correspondence and tracts seethe with a hatred of the literary aristocrats of Louis XVI's France. Marat curses the rulers of the 'egalitarian' 'Republic of Letters' as despots. It was in the depth of this literary underworld that Marat became revolutionary.

\footnotetext{
${ }^{107}$ Ibid., 14.

${ }^{108}$ Gough, The Newspaper Press in the French Revolution, 17.

${ }^{109}$ Darnton, The Literary Underground of the Old Régime, 17.
} 
During the summer of 1789 , as the final restrictions placed on the press were alleviated, the denizens of Grub Street rose to new positions of power. The end of the old regime opened up a new era for the political press, and also for journalism: what emerged in 1789 was not only a set of new titles, but a new subject matter. The new occupation that emerged with the press was that of the campaigning journalist. No longer the detached observer of an event, men like Marat would seek to become participants in them. This new brand of revolutionary journalist used his newspaper not as 'an analytical mirror held up to the face of reality, but as a weapon.' 110

Babeuf From Picardy to Paris, 1788-1794:

The Alienation and Creation of a Revolutionary

Though Babeuf did not take pen to polemic until 1791, his Thermidorian style and language is traceable to the Grub Street style of the 1780s. Like Marat, Babeuf became revolutionary through a poignant sense of alienation. However, unlike Marat, Babeuf's rhetoric would be born of two distinct experiences: his failed attempt to achieve a place within the elite society of Arras, and the denunciation and excommunication from the Thermidorian regime.

${ }^{110}$ Gough The Newspaper Press in the French Revolution, 35-36. 
As a minor advocate ${ }^{111}$ in Picardy, Babeuf believed that his talent as surveyor deserved greater social recognition. Though he had been a corresponding member of the Académie since 1785, Babeuf applied for an honorary membership in the Académie d'Arras in 1787. Babeuf was out of his social depth. The much sought after prize of honorary membership had been extended to only twenty-one out of fifty-six applicants in 1786 . Of the three full members admitted during the same year, two were advocates of the Conceil d'Artois and another was a major in the engineers. ${ }^{112}$ Babeuf would write that he was both shocked and angered by the 'deafening silence' of the Académie. His own opinion of his works made him believe that he deserved membership, and when his entrance was repeatedly blocked by the minor gentilhommes and noblesse of Artois, Babeuf became increasingly convinced his nomination was censured by elitism and privilege.

However, Babeuf would not give voice to this conviction until 1794. Until his denunciation by Guffroy, Babeuf maintained a naive confidence in the government and the new social order of France. Regardless of his roles as a local antagonist against the nobility and tax-collectors in Picardy and as a secretary of the Food Administration

${ }^{111}$ The pre-Revolution career of Babeuf provides another evidence for the argument for Jansenist influence. See David Bell, Lawyers and Citizens. Bell argues that Jansensism had a termendous affect on the legal profession and that its influence extended beyond the Parlement.

${ }^{112}$ Rose, Gracchus Babeuf, 20. 
in $1793,{ }^{113}$ the radical revolutionary career of Babeuf did not begin until November 1794. It is only with the premier edition of le Tribun du Peuple that Babeuf fully embraced his destiny as a peripheral critic of the regime and revolutionary degradation. The reason that Babeuf was so long in achieving his role as a revolutionary was his foundation within the ancien régime.

Unlike many of the Grub Street writers, Babeuf was not poverty-stricken during the final years of the ancien régime. Though his style of polemical language bares many similarities to the ragged pamphleteers and libellistes, Babeuf was a successful land-surveyor. Hardly an outsider in the late 1780 s, Babeuf earned a sizable income within the privileged orders by ransacking feudal archives and devising the greatest possible noble claim of taxation over farmlands. ${ }^{114}$ Though Babeuf would later write that it was within 'the dust of the seigniorial archives that I found the horrifying mysteries of the usurpation of the nobles caste, ${ }^{115}$ it is obvious that Babeuf's professional career as a feudiste was, until the late summer of 1789 , inextricably tied to the fortunes of the second estate.

${ }^{113}$ Babeuf's appointement on 7 November lasted only seven days before he was re-arrested for a prior conviction for fraud. In 1792, while acting as a notary for the sale of church lands in Montdidier, Babeuf had falsified a public document that gave title of land to an individual who had not purchased it. Babeuf was tried in absentia and was condemned to twenty years in irons. Babeuf, however, had fled to Paris.

${ }^{114}$ Rose, Gracchus Babeuf, 11.

${ }^{115}$ F.-N. 'Gracchus'Babeuf, Le Tribun du Peuple, $\mathrm{n}^{\circ} 29$, (Paris: Franklin, 1794),285. 
As the privileged orders fell on 4 August 1789, Babeuf undertook a career in journalism. From 1789 to 1794, Babeuf writes, without either success or recognition, several pamphlets for different political causes. As a hired pen, Babeuf's polemics ranged from the avocation of a new education system in the Correspondant Picard, ${ }^{116}$ to the defense of Garin and the Bureau of Subsistence in 1792, to an open vicious attack on l'ami du peuple, Jean-Paul Marat.

It is the attack on Marat that provides one of the most interesting visions of the pre-Thermidorian discourse of Babeuf. Babeuf was hired by Fournier l'Américain to draft a polemical response to the charges propagated by Jean-Paul Marat. Marat had condemned Fournier and his Defenders of the Republic as rabid, extremist, and dangerous. ${ }^{117}$ Babeuf's response, C. Fournier (L'Américain) à Marat, comprises an eight page pamphlet that states clearly that though Marat might 'still impose on a few citizens' he was a depleted advocate and that the true friend of the people should rally to the defense of sans-culottes, the fixing of the maximum, and control of the rate of inflation. ${ }^{118}$ The irony of this pamphlet lies in the fact that Babeuf rallies to the defense of Jean Lambert Tallien, whose role as a Thermidorian deputy would be instrumental in the radicalization of Babeuf's politics and language.

${ }^{116}$ The Correpondant Picard, Rose argues, like nearly all of Babeuf's ventures was a finacial disater and had only a negligible impact on his home province. The 'journal' had only five editions and an extremely limited readership.

${ }^{117}$ Rose, Gracchus Babeuf, 135.

${ }^{118}$ F.-N. Babeuf, C. Fournier (L'Americain) à Marat, (Paris: Mayer, 1793), 57. 
The journalistic career of Babeuf was one that was spent in isolation and poverty. Though he produced many pamphlets between the fall of the Bastille and the execution of Robespierre, ${ }^{119}$ his endeavors were strikingly unsuccessful. Babeuf's sense of isolation and failure grew steadily as the Revolution progressed. By the summer of 1794, Babeuf had spent nearly two years in prison. His wife, Marie-Anne, who had married a promising young surveyor in 1781 with the assurance of a comfortable life as a minor member of the bar, found herself and her children slowly starving to death in a squalid apartment in Paris. Not only had Babeuf failed to earn a living, by 1794 he was irreversibly indebted to several different printing houses. Babeuf and Marie-Anne only survived through the charity of men like Sylvain Maréchal and Pierre Varin. ${ }^{120}$ As a result of this despair that Babeuf began to embrace what Rose calls a language of 'apocalyptic tone.'

\section{The Reformation of Republican Ideology in Thermidor}

The language of both le Journal de la Liberté de la presse and le Tribun du Peuple, despite it usage, evidences a continuity. The language of both Thermidorian journals was powerful and unified because Babeuf believed the propaganda. In both journals, it is evident that Babeuf wanted to slough off the corrupt world and integrate into the

${ }^{119}$ For a complete listing of the publication of Babeuf see appendix II.

${ }^{120}$ Rose, Gracchus Babeuf, 153. 
Republic of Virtue. Thus, there is no contradiction between Babeuf's condemnation of Robespierre and Fréron. The movement from the Thermidorian camp back to the Jacobins, rather, evidences the synthesis and coherence of Babeuf's discourse The unifying theme between le Journal de la Liberté de la presse and le Tribun du Peuple is Babeuf's criticism, not of individuals, but of elitism and hypocrisy. Babeuf was a cultural revolutionary who wanted to destroy the aristocracy of the mind and the state in order to create an egalitarian republic. Babeuf, in essence, functioned as the ideological carrier who sought to inject the crude, Jacobinical version of Rousseauism into the Parisian san-culotterie. ${ }^{121}$

Unlike the libellistes of the ancien régime, whose works lacked coherent programs, Babeuf presented le Tribun du Peuple as testament to the reconstitution of society. He did not seek to deride all aspects of the current government. Rather, Babeuf presented a critical vision of corruption of the Thermidorian regime. The pages of the le Journal de la Liberté de la presse and le Tribun du Peuple spoke for what Darnton called 'an intellectual sub-intelligentsia.' 122

Babeuf's readers were not the reinvented salon society of the postRobespierrist republic. They were the same cafe society that existed as unintregrated and beyond the political pale. Babeuf was a Rousseauist who wished to reform society by overrunning it. His vision, as it became clear in the pages of the le Tribun du

${ }^{121}$ Darnton, The Literary Underground of the Old Régime, 40.

${ }^{122}$ Ibid., 40. 
Peuple was a rebellion against the Voltairean vision of serving humanity honorably. Babeuf's vision of society was marked by a clear distinction that inequality in possession and position needed to be eradicated. In 1789, the division was one of estates, in 1791 is was active and passive citizenship, in 1793 it was republican and counter-revolutionary. However, by 1794 this distinction had become more severe. Babeuf divided society into the corrupt and the virtuous. He spoke to the virtuous, to those whom the Thermidorian government wanted to condemn as the deviants and the criminals.

A.-B.-J. Guffroy justified his rupture from the printing of the le Journal de la Liberté de la presse by chastising Babeuf's writings as having a naiveté of discourse. By pandering, as Guffroy contested (and Babeuf admitted) to the remnants of the unrepentant Jacobins, le Tribun du Peuple produced a propaganda that is 'both flawed and dangerous to the Republic':

Mais quand j'aperçois que tu t'abandonnes à une exagération, que je ne veux pas encore croire coupable, malgré quelques infidélités que je vais relever. . Mais je ne trouve dans le reste de tes idées que contradiction palpable, qu'erreur blâmable dans un homme éclairé. . . Crois-moi, Babeuf, si tu écris encore, quitte ce langage qui prête des forces à l'intrigue, des armes aux enemies de la patrie. . . Ce langage peut tromper le peuple et sert les vrais factieux. . Tu as blâmé avec raison les dénominations factieuese de Marais de Montagne. Je blâme avec tous les bons citoyens la prétention exclusive au patriotisme, et la dénomination des Jacobins. . . ${ }^{123}$

Guffroy writes in his denunciation that it is the language of Babeuf that is dangerous. Guffroy implores Babeuf to desist from incendiary statements that seek to do nothing

${ }^{123}$ Aulard, 'Babeuf et son Imprimeur Guffroy.': 5-8. 
but incite violence against the regime. Guffroy's fear appears to be that Babeuf's

words will serve to reunify the disparate factions of the old revolutionary government.

Babeuf, in response to the castigation of Guffroy writes in his le Tribun $d u$

Peuple, $\mathrm{n}^{\circ} 27$ that:

Guffroy betrayed my confidence. The traitor! When I started my paper I did not leave him in ignorance of the principles on which I proposed to carry it on. . . Guffroy is robbing me outrageously. He reaps all the fruit of my work. My first numbers ran into two editions; he sold an immense number and received the whole profit; he received all the subscriptions, I never got a sou . . . Guffroy is robbing the best of the patriots who subscribed to my paper ... In fact, Guffroy is striking at (assassine) the very existence of the country by quenching the torch of truth. . ${ }^{124}$

Babeuf's response is a tremendous indictment against Guffroy. He blatantly states that Guffroy is corrupted and a criminal. The power of this denunciation is that Babeuf does not rely solely on the injustice done to him. Babeuf casts the wrongs against le Journal de la Liberté de la presse as crime against the nation. In a well-phrased statement, Babeuf utilizes the denunciatory language of Guffroy against him.

Gough argues that when Babeuf first initiated his le Journal de la Liberté de la presse on 17 Fructidor, he embraced the Thermidorian reaction. However, Babeuf realized that the degradation of the Revolution under the Thermidorians was capable of pirating a greater portion of freedoms after the fall of Robespierre than the dictatorship had stolen in year II. Therefore, when he changed the name to Tribun $d u$

${ }^{124}$ F.-N. 'Gracchus' Babeuf, Le Tribun du Peuple, n 27, (Paris: 1794), 230. 
Peuple, on 14 Vendemaire, he joined Lebois in 'defending Jacobinism and san-culotte interests against the social and political agenda of the bourgeois convention.' 125

The patriotic press, with which Babeuf increasingly aligned himself in the late Fall of 1794, continued their condemnation of Robespierre as a tyrant. However, as evidenced by Guffroy's denunciatory letter to Babeuf, the new le Tribun du Peuple chastises the tyrant with a tempered argument. Babeuf argues that what he denounces was not Robespierre himself, but the regime of year II. With this outward cooling of the conflict between the old combatants of the left, a new union of ex-Jacobins and neo-Hérbetists grew. Unified by a common hostility to the consequences, but not the principles, of the revolutionary government, journalists like René-François Lebois' l'Ami du peuple, Babeuf's le Tribun du Peuple joined with the politically partial Journal de la Montagne to form a journalistic flange. ${ }^{126}$

${ }^{125}$ Gough, The Newspaper Press in the French Revolution, 123.

${ }^{126}$ Woronoff, The Thermidorian regime and the Directory, 4. 


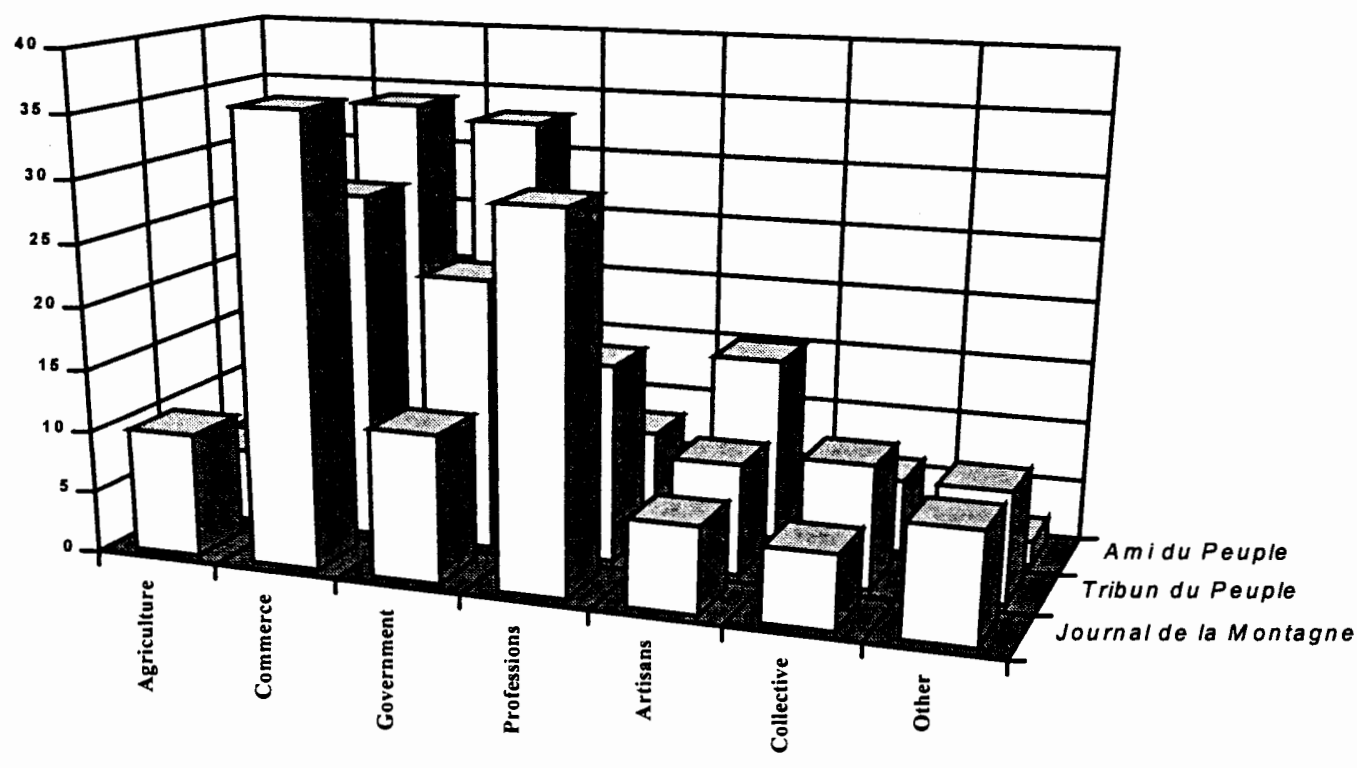

Jeremy Popkin, Revolutionary News, 44.

These redefined Montagnards (see chart II) unified in a demand for unlimited press freedom, for an elected municipality, and for an application of the constitution of 1793.

A consequence of this unity was that Babeuf and the patriotic press re-enforced an old, dualistic distinction between Robespierre and the terrorists and the majority of Jacobins. ${ }^{127}$ As stated earlier, this division of the entity of Robespierre was not a creation of October 1794. Babeuf had written in his le Journal de la Liberté de la

${ }^{127}$ Tønnesson, La Défaite des sans-culottes, 53. 
presse, $\mathrm{n}^{\circ} 1$ that one has to distinguish between 'the sincere patriot and friend,' and 'Robespierre the ambitious and greatest tyrant of this epoch.' It is, however, within this new atmosphere of Jacobin re-invention that this metaphysical concept becomes perfected by Babeuf.

Tønnesson argues that le Tribun du Peuple satisfied a specific need and provided a clear and aggressive venue for the antagonism of the social policies of the Thermidorians. ${ }^{128}$ Along with Lebois and Vatar, Babeuf's le Tribun du Peuple maintained the morale and the cohesion of the surviving revolutionary opposition in Paris during the winter of 94-95 (see chart II). 'Decimated by arrest, terrorized by the Jeunesse dorée, disillusioned by the persistence of popular apathy' only a handful of sans-culottes were ready to declare their allegiances openly. ${ }^{129}$

Babeuf's journal provided a reassurance of the stubborn persistence of the old guard radicals. Babeuf warned the Thermidorians that the closing of the Club Electoral and the Jacobins, ${ }^{130}$ 'far from crushing the organized opposition' it had merely changed its tactics. Babeuf prophesied that every garret and every slum would become its own popular society. As his distance from the Thermidorian camp grows, the vitriolic nature of Babeuf's writings gets stronger. While Lefebvre argues that Babeuf

${ }^{128}$ Ibid, 154.

${ }^{129}$ Rose, Gracchus Babeuf, 153.

${ }^{130}$ These two subjects would make up the subject matter of a majority of Babeuf's Thermidorian journalism. A more thorough analysis of this discourse is the objective of Chapter III. 
was nothing more than a crypto-Thermidorian, ${ }^{131}$ the language of Babeuf in the weeks after his fall-out with Guffroy proves that he is an ardent critic of the regime.

The new venue for Babeuf became the garrets and the popular cafes of the faubourgs. Public readings of le Tribun $d u$ Peuple provided a rallying point and new center for the hidden, but vocal opposition to the Thermidorian regime. ${ }^{132}$ The popularity of the new, independent journal grew until, as Rose states, 'printings of 2,000 were inadequate to meet the demand.' 133

Sensing the beginning of a new upsurge in popular agitation, the popular societies of the Quinze-Vingts and the rue du Vert-Bois launched a new agitation for the immediate introduction of the 1793 constitution. With Babeuf as their journalistic lead, Paris appeared to be coming out of its post-Robespierrist apathy. On 10 January the popular leaders of the Gravilliers Section General Assembly, Petit and Camelin were arrested for petitioning the Convention for the introduction of the Constitution of 1793. As the ringleaders of the sections sat in Le Pleiss prison, Babeuf set pen to paper to call for a peaceful, mass march on the Convention to protest their grievances.

${ }^{131}$ Georges Lefebvre, The Thermidorians, trans. Robert Baldick, (New York: Vintage Books, 1966), 6 [Originally published as Les Thermidoriens (Paris: Max Clerc et Cie, 1937)].

${ }^{132}$ The public readings of Babeuf's pamphlets is an area that has never been researched. It appears that the public readings of these works achieved one main goal: greater diffusion. Though the literacy rate among Parisians was very high, it was not universal among the lower levels of the artisan population. In addition, the cost of a journal was prohibitively expensive. By reading a journal outloud, the necessity of literacy and capital were greatly reduced.

${ }^{133}$ Rose, Gracchus Babeuf, 180. 
Babeuf declared in issue $n^{\circ} 29$ of le Tribun du Peuple the necessity for a new mandate on the deputies of the Convention. Babeuf demanded that the Convention lay down a program to assure a set level of inflation for the future. This program, to the consternation of the Convention, called for the population of Paris to rally behind Jacobin leadership. ${ }^{134}$

The exhilaration that Babeuf sensed in popular societies was fleeting. On 2 February, Boursault, representative on mission to Brittany, added further concern to the Convention when he reported that the incendiary words of Babeuf had influenced the people of Rennes to riot over bread prices. The discourse of Babeuf, having been liberated from the influence of Guffroy, raised a new voice and a new language of revolution that sought to release the torpor of the people. In one of his most moving anti-Convention tracts, Babeuf writes:

Where is the convention then? The journée of 9 Thermidor has only kept France from having an acknowledged master. In fact ... that journée was not a true revolution. You could have, or rather, you should have supplemented it since then; but where are the laws you have passed to restore to the nation its usurped rights? Where are the decrees exterminating those shameful institutions, institutions more monarchist than those established under the tyrants? What use it is to destroy the man if all that he created remains? The press has been regained, but it is we who have carried by assault, with weapons of reason in our hands. We have been reduced to carrying out this outrage to public reason form the necessity of proving that the freedom to declare one's thoughts is a legitimate right. This has been turned into a problem in your chamber. You gave hardly any sign of tacit approval for this freedom, and at the first resistance which you were seen to make against this eternal and indefeasible right, it remained unclear, in the judgment of many, if your tolerance in this respect has not been communicated by the strength of the general will, which despite you seems to decree the protection of free writers. . . Fellow citizen, you are once again under the reign of trollops. The Pompadours, Du Berrys, and Antionettes have come to life again, and it is they who are governing you. It is they who are largely responsible for all the calamities that have beset you and the deplorable regression that is killing your

${ }^{134}$ Ibid. 
Revolution ... Why keep it a secret any longer that Tallien, Fréron, and Bentabolle are deciding the fate of human beings while reclining indolently on down and roses, next to princesses? ${ }^{135}$

Though Babeuf insisted that there must be 'no torrents of blood and no heaps of corpses,' the call for insurrection and the advocating of the Robespierrist regime could not be ignored by the Convention. Naftel, a police agent, received orders on 3 February to arrest Babeuf. Naftal proceeded to a wine merchant's house on the rue des Champs-Elysées. All Naftal found was Marie-Anne and the three Babeuf children living in near starvation. ${ }^{136}$ By 9 February, the pressure from Guffroy and the

\footnotetext{
${ }^{135}$ F-N. 'Gracchus' Babeuf, Le Tribun du Peuple, n 29, (Paris: Franklin, 1794).

${ }^{136}$ Richard Cobb, "L'Arrestation de Babeuf à Paris, le 20 pluviôse, an III" Annales Historiques de la Révolution Française, $\mathrm{n}^{\circ} 165,(1961)$ : 393-94.

Later that day, however, Naftal and the Police did arrest Jean-Robert Carin. Though Carin could not give any information as to the hiding place of Babeuf, the police did interogate him heavily. The only information ascertained was that Carin
} 
Convention forced the police to close in and enforce the arrest warrant signed by

Guffroy. Babeuf was silenced and condemned to prison in Artois, northern France. ${ }^{137}$

admitted to publishing several pamphlets and three entries in Le Tribun du Peuple. There is no other mention of the printer or the printing house. One irony is, however, that Carin had just received a draft of Babeuf's Le system de dépopulation. It is obvious that the police did not bother to read the pamphlet. Though it stated that Robespierre and the Convention had created the Terror as an effort to lower the population growth to ensure adequate arable land for all families, the pamphlet was allowed to be published and widely circulated on 3 February.

${ }^{137}$ Since late October, Babeuf had existed in a near total isolation. Having been denounced by Guffroy, Babeuf composed his pamphlets and journals in dark basements. R. B. Rose argues that Babeuf's three month isolation was made possible by the tacit refusal of the police to arrest a 'republican in good standing.' 
[III]

'IF LIBERTY PERISHES HERE.'

Babeuf, the Imprimerie de Franklin and the

Revolutionary Language of The Thermidorian Reaction

'The republic is lost, the brigands have won.' 138

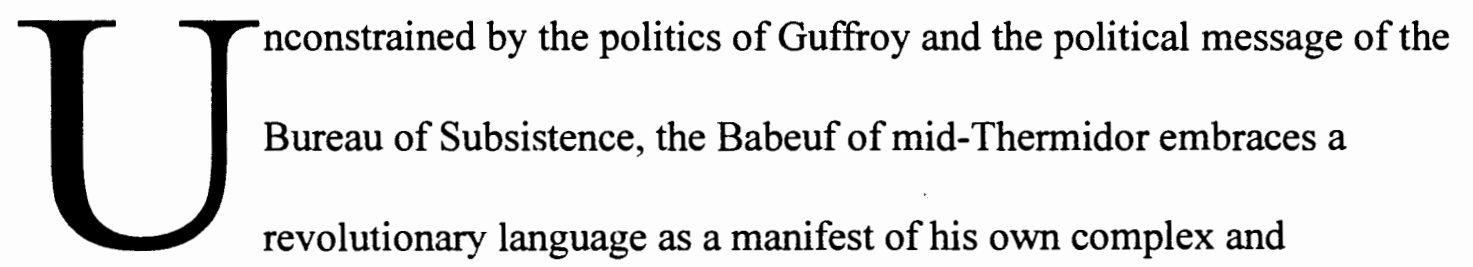

paradoxical ideology. ${ }^{139}$ By December 1794, Babeuf had recreated himself as a

radical patriot. Undaunted, unfettered, and unquestionably anti-Thermidorian, Babeuf began his short, but prolific association with Jean-Robert Carin's Imprimerie de Franklin by a developing vision of the historic role of Robespierre and the Jacobins.

Babeuf devises a commentary on religion and purity that separates him forever from his roots as feudiste and hired pen. Unlike the tracts produced for Garin and Fournier, the seven tracks published under Jean-Robert Carin's Imprimerie de Franklin are fascinating because they are the first true glimpses of Babeuf's language. The tracts

${ }^{138}$ Maxmilien Robespierre, 9 Thermidor, year II.

${ }^{139}$ For a more complete analysis of Babeuf's revolutionary language, see appendix III: Babeuf and Critical Theory: A Study of Revolutionary Language. 
produced during the Winter of 1795 were heavily influenced by the political climate of the Thermidorian regime. In the midst of the politics of denunciation and the betrayal of the Jacobins, Babeuf aligned with the publisher Jean-Robert Carin to find his voice to decry the hypocrisy of the terrorists-turned-Thermidorians. Through an examination of Babeuf's On veut sauver Carrier, Les battus payant amende, and Voyage des jacobins, Babeuf conceives both a harsh denunciation of the corruption of the Jacobins, a bitter condemnation of the Thermidorian Convention, and philosophical justification of Robespierre and the Terror.

The association of Babeuf and Carin began in November, 1794. A little over three weeks after Guffroy ceased publishing the le Journal de la Liberté de la presse (14 October), Carin's Franklin produced On veut sauver Carrier (7 November).

Carin's printing house went on to produce five other pamphlets ${ }^{140}$ and two editions of le Tribun du Peuple. ${ }^{141}$ Within these works, the voice of the Babeuf who was be tried for a conspiracy in 1797 is first heard. These tracts are filled with a language and symbolism that moves from pure political lucidity to spiritual abstraction to incoherent utopianism. Through it all, however, Babeuf maintains certain tenets and visions that unify and produce his Thermidorian discourse.

${ }^{140}$ Les battus payant amende, On veut sauver Carrier, Le systeme de depopulation, G. Babeuf/Tribun du Peuple à ses concioyens, and Voyage des jacobins.

${ }^{141}$ le Tribun du Peuple $\mathrm{N}^{\circ} 28$, and le Tribun du Peuple, supplément du $n^{\circ} 29$. 
Branislaw Bazcko, however, attributes very little interest into the seven texts published by Imprimerie de Franklin during Thermidor. Bazcko wrongly asserts that texts like Voyage des jacobins, Les battus payant amende and On veut sauver Carrier evidence a 'great confusion' on the part of Babeuf as to the direction of the Revolution. ${ }^{142}$ What Bazcko sees as confusion is actually continuity. Les battus payant amende, Voyage des jacobins, and On veut sauver Carrier provide an explanation and criticism of the language and corruption of Robespierre and the Jacobins. The pamphlets were all written and published between 26 Brumaire and 19 Frîmaire, III. When examined together, these three pamphlets provide a unique and polemical history of the early Thermidorian regime.

In these pamphlets, Babeuf chastises the Jacobins for their arrogance and tyranny. However, Babeuf institutes a subtle acknowledgment of the essential revolutionary role of both the popular societies and the uncorrupted Jacobins. In Voyage des jacobins, Babeuf writes:

If it were true, as you [Jacobins] want it to be heard, that the measure taken against the Mother-Society, was a project intended to annihilate all the popular societies, it would be necessary, without doubt, to react against the oppression. ${ }^{143}$

${ }^{142}$ Bronislaw Baczko, Ending the Terror: The French Revolution after Robespierre, trans. Michel Petheran, (Cambridge: Editions de la Maison des Sciences de l'Homme and Cambridge University Press, 1994), 182.

${ }^{143}$ F.-N. 'Gracchus' Babeuf, Voyage des jacobins dans la quatre parties du monde: avec la Constitution mise à la ordre du jour par Audouin et Barrère, (Paris: Franklin, rue de Clery 75, 1794), 7. 
However, this passage cannot be read as a call to arms. Far from advocating insurrection, Babeuf calls upon the maligned Jacobins to 'await the justification from the people and from the republican constitution.' Babeuf asserts that the Jacobins, despite their betrayal of both the nation and their own ideology during the Terror are protected by the Constitution. Babeuf further asserts that the Jacobins must act 'like a bulwark against the enterprises of each of the depositories of power [the Thermidorian Convention].' Failure to await the general will of the people, Babeuf asserts, will not serve the nation. It will, rather, show that Jacobin:

aggression would likely become seen as an exercise in despotism, to steal, in the name of liberty and all that has been the most respectable, the legitimate power of the people, only to re-establish a carnage and terrorism until the point that would substitute a race of devourers for the race of men ... ${ }^{144}$

Though Dommanget and other historians have read this passage as a strictly antiJacobin polemic, Babeuf is quick to differentiate between a pure and a tainted form of Jacobinism. What marks these pamphlets more than the superficial anti-Jacobin rhetoric is the deeper division that Babeuf creates within the Jacobin party. Les battus payant amende, On veut sauver Carrier, and Voyage des jacobins are filled with vitriolic attacks on Carrier, Barère, Collot-Herbois, Billaud-Varenne, and the other Thermidorian Jacobins, as well as Fréron and Tallien, the 'weather-vanes of Thermidor.' The pamphlets listed above, when read together, give a blueprint to the ${ }^{144}$ Ibid. 
unfolding discourse of Gracchus Babeuf. In addition, the language of Babeuf evidences the continuity of his discourse.

The Thermidorian Synthesis?

The liquidation of the factions, of the Dantonists and of the Hébertists, had set the tone for Jacobin language. The slanders of the Terror used all possible rhetoric to 'win over the undecided to the cause of the Convention' and to 'consolidate the resolution of those who had already been won over." ${ }^{145}$ Under the Mountain, all political debate was stifled by the "glorifying of the unanimous and indivisible people." 146

The Thermidorians, however, were unable to construct a new linguistic system. Their discourse could do nothing but attempt to destroy and disorganize the Jacobin language by placing the rhetoric of a jealous parlementary equality in place of the 'citizen'. Unlike the overtones of universality under the Mountain, the Thermidorian language was, according to Mathiez, created for 'the service of private appetites and passions. ${ }^{147}$ This co-optation of the verbiage resulted in a metamorphosis of meaning to suit the new governmental perspective. It did not, however, alter the initial structure of the language. Though the ideology changed, the edifice remained constant. This construction allowed Babeuf to utilize and manipulate the language of the regime

${ }^{145}$ Baczko, Ending the Terror, 17.

${ }^{146}$ Ibid., 27.

${ }^{147}$ Mathiez, After Robespierre, 20. 
to both denounce and praise Robespierre. Thus, for the linguistics of Babeuf, the language of denunciation is tied directly to the discourse of praise. It is within this relative union of opposing rhetoric constructions that the writings of Babeuf must be placed. Babeuf forms a critical juncture of Jacobinical discourse.

Like all political discourse after 9 Thermidor, both Babeuf and the Jacobins refer to the 'fall of the tyrant' and to the 'happy revolution.' However, neither Babeuf nor the Jacobins entirely disassociate themselves from their own common past. While they both decried the corruption of the order, they simultaneously 'glorified unceasingly' their 'unconditional devotion' to the Revolution. The language of Babeuf and the Jacobins evidence their vigilance, their struggles and their supreme sacrifices in seeing the Revolution to its ultimate and triumphal success. ${ }^{148}$

For Babeuf, the Jacobins, and even the Thermidorians, the impetus to create a distinct discourse was irreversibly tied to the tradition of Robespierre. At the height of the Terror, Robespierre was recognized as the embodiment of the pure and virtuous Republic. After the fall, the pure and virtuous Republic had to be separated from the memory of the corrupt and tyrannical Robespierre.

The fear of the Convention and the patriots was that to discredit Robespierre too fully ran the risk of discrediting the Revolution as a whole. ${ }^{149}$ The reaction to this political reality manifested itself in distinct discourse. Unlike Babeuf, who sought to

${ }^{148}$ Baczko, Ending the Terror, 21.

${ }^{149}$ Ibid. 29. 
create a metaphysical duality in Robespierre, the Convention reacted violently against the Jacobins. The Thermidorians argued that France had reason to fear and mistrust the Jacobins. The continued existence of Robespierrist radicals after the fall of the Mountain promised an inevitable return to the butchery of the Terror.

What the rhetoric of both the Thermidorian Convention and Babeuf agreed upon was that Robespierre had, in 1793, embodied and combined the two most fundamental elements of revolutionary legitimacy. Neither Babeuf nor the Convention wished to oppose the ideals of representative government and direct democracy. Thus, the distinction between Babeuf and the Convention within the political language of Thermidor is whether to celebrate or assassinate the memory of Robespierre. JeanPierre Audouin, the editor of the Journal universal, commented on 20 Thermidor on the Convention's rhetoric of separating the seated legislators from their own history:

I thrill with indignation when, under the pretext of patriotism, the aristocrats tell us that the revolutionary government is terrible, that it is time to crush it, that we must have no more popular societies, that we must guillotine this or that republican who has served the country, that we ought to regard even the federalist leaders as patriots. What more can I say? perhaps we shall soon be told that we must recall the émigrés. ${ }^{150}$

To accuse the Jacobins 'of all evils', to present them as the principle support of Robespierre yesterday and as a 'lair of brigands' today was a way of discharging the Convention of any responsibility for its own activity, or inactivity, during the Terror.

${ }^{150}$ Mathiez, 27. 
${ }^{151}$ Billaud-Varenne, who would later regret his association, agreed with this

Thermidorian rhetoric. As a Jacobin who had conspired against Robespierre, he said:

May this example [of the corruption and fall of Robespierre] teach you never again to have an idol. You were victims of La Fayette, of Brissot, of a host of other conspirators. . Rally around the Convention which, at these stormy moments, has displayed the greatest character. It will show mercy to no conspirator and virtue will always be the basis of it operations. ${ }^{152}$

Billaud-Varenne and the Thermidorians publicly cultivated a new 'moderate clique' of supporters who would back them in the galleries of the Assembly. ${ }^{153}$

The most successful Thermidorian tactic to drive a sharp and definitive distinction between Thermidor and Terror was the famed list of Robespierre. When Couthon, a remnant of the Jacobin regime, was forced to explain the list of deputies that Robespierre had purportedly created to purge the convention, Couthon maintained that it was 'only a matter of purifying the Convention of a few scoundrels.' 154 This 'mysterious list for proscriptions of the deputies' was then put into circulation by the publisher Guffroy. This list was aimed as a double blow. It successfully divided the remaining Montagnards into two camps: those whose names appeared on Robespierre's list and those who composed the queue de Robespierre. The division of

${ }^{151}$ Bazcko, 112

152 Ibid., 97.

${ }^{153}$ François Gendron, La Jeunesse dorée sous Thermidor, (Paris: Les Presses Universitaires de France, 1983), 9.

${ }^{154}$ Bazcko, 31. 
the Jacobins eliminated the immediate fear of radical retribution for the execution of Robespierre.

Secondarily, Robespierre's list showed that the Convention was seen by Robespierre and the regime as being anti-Robespierrist. In the days after 9 Thermidor, deputies whose names appeared on Robespierre's list attempted to establish themselves as historic enemies of the reign of Terror. The published list justified to the majority of the deputies the arrest and execution of Robespierre, Saint-Just, and Couthon. The list also provided an opportunity for the Convention not to face responsibility for the Terror. By shifting the onus for the birth, maturation, and ultimate corruption of the Terror to the Triumphers of Robespierre, Saint-Just, and Couthon, the National Convention absolved itself of both the responsibility and culpability of the Terror.

Babeuf seized this radical revolutionary rhetoric and reinvented the classical age. His late Thermidorian writings float on classical lessons for the instituting of a new order. Babeuf, as Robespierre had done earlier, 'utopianized' classical history to fit the model of a new and innocent society, and an ideal Republic. ${ }^{155}$

${ }^{155}$ Lynn Hunt, Politics, Culture, and Class in the French Revolution, (Berkeley: Los Angeles: University of California Press, 1984), 28. 
The Destruction of Thermidorian Consensus:

Babeuf, the Jacobins and the Freedom of the Press

The coup-d'etat of Thermidor aroused a deluge of caustic pamphlets '.. a storm of invective against the 'knights of the guillotine, the lovers of mass drowning, and the killers à la lyonnaise." 156 On the whole, the language of these tracts contained nothing more than ubiquitous denunciations that had been made systematic by Hébert and Guffroy: the Jacobins are generally accused of 'sharpening their daggers in silence' and being the 'deceivers' and 'oppressors' of the people. ${ }^{157}$ Bazcko declares that the 'unanimous condemnation of Robespierre's tyranny found its logical extension in freedom of the press and opinion.' By instituting the freedom of the press, it is assumed that the conditions were made to make justice 'l'ordre du jour!' 158

In this reactionary press, the Jacobins are damned as restricting the freedom of the press for fear of being 'unmasked' (démasqués). Jacobins are also lambasted for forming a new 'aristocracy,' for monopolizing jobs for their members, for destroying commerce, and for distributing the white cockades of royalism. ${ }^{159}$ The recalcitrance of the Jacobin discourse was also seen as a product of their longing for the return of the Terror.

${ }^{156}$ Gendron, La Jeunesse dorée sous Thermidor 16.

${ }^{157}$ Ibid., 18.

${ }^{158}$ Bazcko, 79.

${ }^{159}$ Gendron, La Jeunesse dorée sous Thermidor, 17. 
After 9 Thermidor, the majority of Jacobin Club members were castigated for support of the continuance of press restriction. The Jacobins feared that a complete relaxation of censorship would only give free rein to the rapidly mounting forces of political reaction. Freedom of the press, despite Fréron's statement on 9 Fructidor that '[T]here is nothing more fatal to anarchy than the right to say and write anything' was viewed by the Jacobins as a method to 'encourage the return of the right-wing press, and hasten the end of the revolutionary government' and the revolution. ${ }^{160}$

On 9 Fructidor, Fréron proposed a decree to guarantee the unrestricted freedom of the presses. Amar and the remnants of the Jacobins, however, blocked the motion for approval in the National Convention. The argument against the Jacobins was made more poignant. The popular belief that the Convention had rid itself only of Robespierre while France still suffered under the Jacobins, In reaction to Fréron's statement deputies decried the Jacobins as longing for the restrictions of the Terror. On the same day, La queue de Robespierre was published by Guffroy, and the popular anti-Jacobin crusade was unleashed.

The Thermidorian freedom of the press, despite Jacobin objection, was obtained after the fall of Robespierre. In the aftermath of 9 Thermidor, right-wing papers run by talented journalists, such as Dussault's le Correspondence politique and Richer de Sérizy's L'Accusateur publique, joined with the new moderates like Fréron

${ }^{160}$ Hugh Gough, The Newspaper Press in the French Revolution, (Chicago: Dorsey Press, 1988), 119. 
and l'Oratuer to incite the population to revenge. The freed press gave instructions for action and pointed out the most dangerous Jacobins. ${ }^{161}$

The object of Fréron, Tallien and the 'New Indulgents' of Thermidor in demanding, 'with such insistence,' a new and unlimited freedom of the press was not to placate the remnants of the Hébertists ${ }^{162}$ but rather to use this liberty as a principle from which to attack their adversaries and predecessors. ${ }^{163}$ Isore, the editor of the Courier Republicain was one of the lone voices that supported the Jacobin recalcitrance. Despite the rhetoric of the moderates and right, Isore realized that sudden emergence of an unrestricted press would result in a severe and brutal denunciation of the Jacobins. On 19 Fructidor, Isore writes:

I am not surprised that people want to have it believed that the Jacobins do not want press freedom. But it is false. Jacobins only reject unlimited freedom, something that is irreconcilable with revolutionary government. I make the observation in order to refute in advance anyone wanting to denigrate our club. ${ }^{164}$

Babeuf, as well, though professionally interested in the creation of a free press, states his own concerns. In his Voyage des jacobins, Babeuf writes that though

All announce that this system [the freedom of the press] will not degenerate from its primitive purity; all prognosticate in the same terms that we have touched on the principles that are eternal ... One of these quacks, the immoral Barrère [sic], preceded by A. Audouin, come from us to throw out the fancy of the (freedom of the)

${ }^{161}$ Woronoff, The Thermidorian regime, 3.

162 The Hébertist had demanded direct government and unrestricted freedom of the printing and publication, at least for right minded Republicans, during the Terror. Their demands had won the animosity and condemnation of Robespierre.

${ }^{163}$ Mathiez, After Robespierre, 36.

${ }^{164}$ Gough, The Newspaper Press in the French Revolution, 121. 
constitutional regime. It is because he ... this malfeasant Bertrand, this wicked old sack ... sees that the majority of the French desire it [freedom of the press] and that he is never wanting to deprive the Republic. ${ }^{165}$

Babeuf's tract provides a poor vision of Bertrand Barère. For Babeuf, Barère assumes a role of the quintessential corrupted Jacobin. Babeuf explains him as a self-serving drunk who thinks of nothing but himself and thrives on corrupting the virtues of the nation. Babeuf shows himself as supporting the majority of the Jacobin Club in questioning the motives of Fréron's decree. Barère, however, is shown placating the public taste.

If the Thermidorians were successful in placing the freedom of the press in their specialized pantheon of dogma, they did so in belief that this would win them the support of the Jacobin journalists who had been silenced and censured under Robespierre. The Thermidorians aimed at a unanimity in revolutionary language. Much like Robespierre and the Jacobins, the discourse of the Thermidorian press was to be bought and sold as collateral against opposition.

Mehée's La Queue de Robespierre, a pamphlet denouncing the Jacobin remnants of the revolutionary committees, is nearly unparalleled in its viciousness and success. Guffroy and the Thermidorian press were successful in conceiving of a vitriolic language in this pamphlet that both condemns the moderate Jacobins and supports the Convention as a moderate and popular alternative. Collot d'Herbois, 
Carrier, Barère, and Billaud-Varenne, all the Jacobins who had been lauded as victors, and who had brought the downfall of the tyrant were instantly recast as the dangerous 'continuators of Robespierre.' 166

Babeuf, in his Les Battus payant amende, criticizes the method by which the Thermidorian press presents itself. 'A pamphlet only sells itself,' Babeuf writes, 'when it carries a cutting title.' He continues that a paper is only purchased:

when it gives life to those things that make us laugh, and when we find in it an affirmation in step with our own morality. . . It is necessary for the philosophic writer who wishes to pass on certain useful instructions or reflections to prepare to find himself characterized as no longer 'revolutionary' 167

However, regardless of his criticism, Babeuf openly admits that his Les battus payant amende and Voyage des jacobins are conceived in a similar vain. 'The premise of this is contraband' he writes in Les battus payant amende, 'the writing is in your hand, and that is all that I want ... ${ }^{168} \mathrm{He}$ continues that:

The most important political truths will not appear if they are not placed inside complimentary envelopes and epigrams; perhaps it will be necessary to reduce opinions to candy, and then one will find the republican morality in these packaged mottoes ... It is necessary to conform to the national taste ... you have read a salient and ironic title, an epigraph and an exhortation in itself, you have not returned to those 'print-sheets' and my pamphlet has been purchased. ${ }^{169}$

${ }^{166}$ Mathiez, After Robespierre, 37.

${ }^{167}$ F.-N. 'Gracchus' Babeuf, Les battus payant amende: ou les Jacobins jeannots, (Paris: Frankin, rue de Clery 75, 1794), 2.

${ }^{168}$ Ibid.,

${ }^{169}$ Ibid., 2-3. 


\section{On veut sauver Carrier:}

Carrier, the Trial of the Four and the Radicalization of Babeuf.

The month of Fructidor, year III provided a splendid opportunity for the

Thermidorians to distance themselves from the Terror and for Babeuf to disassociate himself from the Thermidorian regime. The Thermidorians manipulated the trial of the ninety-four citizens, arrested by Carrier in Nantes as revolutionary centrists during the Terror, to distance themselves from their Jacobin origins. The defense of these Vendée rebels was based on the Convention's belief that their arrests were due to the fact that they were Muscadins. The trial provided a splendid opportunity for the journalists and lampoonists alike to both discredit the Revolutionary Government of Robespierre as factionalist, and to show that the new Thermidorian government was both forgiving and republican.

The trial, François Gendron argues, tipped the scale of public opinion once and for all towards the Thermidorians and against the Jacobin club. By aligning the image of Liberty against the Terror, the Thermidorians created an image of Jacobins as 'drinkers of blood' and counter-revolutionaries. ${ }^{170}$ Babeuf commented that:

This manner of identifying liberty with the Jacobins! Liberty has been poorly advised if it has put its destiny in their hands. ${ }^{171}$

${ }^{170}$ Gendron, La Jeunesse dorée sous Thermidor, 19.

${ }^{171}$ Babeuf, Les battus payant amende, 18. 
The trial was the fruition of the Jacobin fear that Fréron and the new right (the successful inheritors of the Jacobinical schism of 9 Thermidor) sought from the outset to silence and discredit the remnants of the Jacobins. It was from the defense of this trial that Fréron and Tallien began their demand to secure the closure of 'the den of thieves.'

With the acquittal of the ninety-four, the objective of the empowered right was now to discredit, silence and bring to trial those remnants of the Jacobin left. Fréron and Tallien turned their attention to the Jacobins that had aided in the overthrow of Robespierre and remained in power after the fall of the Robespierrist regime. The justification of the trial of the Four, Collot d'Herbois, Barère, Billaud-Varennes, and Vadier, was undertaken when, on 23 Fructidor, the deputy Duhem referred to the centrist representatives, (many of whom were Jacobins) as the 'toads of the March.' Billaud-Varennes replied that 'A slumbering lion may look dead. But when it awakens, it exterminates its enemies.' ${ }^{172}$ With Billaud-Varennes' assertion, the fate of the remaining Jacobin and centrist deputies was defined and executed. He had established that, to the ears of Fréron and Tallien, the Jacobins were not dead, but rather were waiting to awaken the nascent republican virtues of the French people.

Soon after Duhem's denunciation of the center, Fréron decided to split definitively with his old allies of 9 Thermidor. The problematic aspect of the decision

${ }^{172}$ Gendron, La Jeunesse dorée sous Thermidor, 4. 
to peruse a trial was how far to go? If Fréron and the ex-Jacobin deputies refused to take action against the recalcitrant four terrorists, would the Convention appear to condone their 'crimes?' However, Fréron realized if the Convention brought proceedings against them, the accused would defend themselves by saying they acted in accordance with the wishes of the National Convention. The result, the moderates comprehended, would be a public trial that would prove that Barère, Collot d'Herbois, Billaud-Varenne, and Vadier were no more guilty of revolutionary crimes than Fréron and Tallien. ${ }^{173}$

The fear was that the trial would be turned into a trial of the National Convention itself. The political decision rendered by Fréron manifests the 'fragile balance of power' within the Convention. ${ }^{174}$ The trial was conducted by Saladin, whom Gendron describes as 'a vindictive Girondin who intended to waste no time in conducting the inquiry.' ${ }^{175}$ The trial was marked by vitriolic attacks on all sides. The ephemeral leaders of Thermidor - Barrère, Collot d'Herbois, Billaud-Varenne, and Vadier- were isolated in the government by new and old soft-liners. The trial was conducted by those who sought to distance Thermidor, its leadership and the governance of the Republic, from the Terror. The four were successfully cast, tried, and condemned as the vile remnants of Robespierre.

$$
\begin{aligned}
& { }^{173} \text { Ibid., } 37 . \\
& { }^{174} \text { Ibid. } \\
& { }^{175} \text { Ibid., } 44 .
\end{aligned}
$$


Naively, Barère had stated on the 24 Thermidor that 'the traces of personal revenge will vanish from the soil of the Republic.' ${ }^{176}$ By 12 Ventôse, however, Barère's discourse had changed to a denunciation of Fréron for being 'so humane that he demands nothing more than the heads of the republicans and the blood of his colleagues.' 177 On 13 Germinal, the Convention declared that the four should be condemned to exile to French Guyana. All but Vadier, who could not be found, were exiled from Paris on that very day. Vadier would re-emerge in 1796 as an archsupporter of Babeuf in his conspiracy trial.

Another governmental attack against the Jacobins came with the trial of Carrier. The revolutionary career of Carrier is one that aroused suspicion and hatred from Jacobins and Thermidorians alike. His behavior in the field as a representative en mission, coupled with his reputed love of luxury, and use of theft, extortion, tyranny and arbitrary violence made him suspect in the eyes of Robespierre. Robespierre appears to have recalled Carrier from his mission in Nantes for the specific reason of revolutionary zealotry. Robespierre and the Committee of Public Safety feared that the zeal and violence of Carrier would discredit the Terror. On 8 Thermidor, as Robespierre contemplated a purge of the Terror to make its political realities conform to his philosophic principles, the reports against Carrier, and his deviationist and Hébertiste leanings, made him a prime example for a purge. In order to avoid danger,
${ }^{176}$ Bazcko, 67.
${ }^{177}$ Gendron, 45 . 
as well as to save the Republic, the newly recalled representative appears to have rallied early to the anti-Robespierrist plot and even had a hand in its preparation. ${ }^{178}$ At the urging of the right leaning deputies Tallien and Merlin de Thionville, Carrier was brought to trial for his revolutionary crimes. His trial was to be, like the trial of the four (which would take place four months later) a show case for Thermidorian justice. The Convention, by bringing the butcher of Nantes to trial, was to establish itself definitively as a regime of justice. However, in the case of Gracchus Babeuf, the trial of Carrier was to prove to be a tocsin for patriots and republicans.

'The people of Paris' Babeuf writes in On veut sauver Carrier, 'The people of the entire Republic, cry out in unison at the opening of the trial against the most execrable accomplices of the depopulators. ${ }^{179}$ This cry, Babeuf writes:

is that of the most terrible vengeance, called, not on the head, but on all the sensitive parts of the most monstrous being that is produced by nature. Never have such voices of indignation been pronounced against the individual, nor more generally, nor more energetically. Never have such atrocities been heaped up and justified better the public irritation. Carrier, this horrible name grates all ears. ${ }^{180}$

It was agreed, according to Gendron's research, that the revolution should be dismantled slowly, 'to avoid creating any panic in turning back the clock. ${ }^{181}$ As a result, the crimes of 'repentant terrorists', like Fréron and Tallien, would be dismissed

${ }^{178}$ Bazcko, 142.

${ }^{179}$ F.-N. 'Gracchus' Babeuf, On veut sauver Carrier: On veut faire le procès au Tribunal révolutionnaire. Peuple prend garde à toi! (Paris: Franklin, rue de Clery $75,1794), 1$.

${ }^{180}$ Ibid., 2.

${ }^{181}$ Gendron, 19. 
summarily by the Convention under a general amnesty. However, the true weight of Robespierre's system of justice 'would reign down on those deputies whose adherence to or participation within the Thermidorian regime might cause embarrassment to the Convention. In this way, Carrier was to be an example of a representative en mission who had soiled the Terror and embodied the tyranny of Robespierre.

In his On veut sauver Carrier, Babeuf crafts a critical perception of Carrier's crimes. While he writes that:

There is no Frenchman for whom this word [Carrier] does not have enough history to recall the most irascible carnivores... ${ }^{182}$

Babeuf continues on to assess blame to a far greater portion of the government:

Furious Duhem! You gave sanction to these frightful destruction, you absolve the murders of a quarter of France; your spirit is no less barbaric in having done this than his [Carrier]. ${ }^{183}$

To Babeuf, the crimes of Carrier cannot be isolated to a single man. They are the result of the corruption of the Revolution. It was the 'Men of blood and death,' Babeuf writes who undertook the 'general horror' of the Vendée. Babeuf blames, not Carrier, but the Convention itself. Babeuf states the justification of the Terror, and restates how 'the charlatanism of a coldly abominable phrase: 'They [the massacres] were made possible to save the Country! ${ }^{184}$ was reconstituted by the sitting Convention to

\footnotetext{
${ }^{182}$ Babeuf, On veut sauver Carrier, 2.

183 Ibid. 7.

184 Ibid., 8.
} 
justify the closure of the Jacobins and the popular societies. Babeuf warns the Convention that 'These sinister words will not work' that they will not 'repress the indignation' of the French people.' 185

Babeuf writes that Duhem, and the whole of the Convention 'will not escape the vengeance that is demanded and awaited by all the French. ${ }^{186}$ Babeuf uses his On veut sauver Carrier to decry Fréron, Tallien, and the other deputies who had been the most vicious Terrorists under Robespierre. Babeuf explains that the trial of Carrier alone without a judgment against the whole of the system and all its remaining adherents will 'compromise the tribunal' ${ }^{187}$ of the people. Babeuf uses the trial of Carrier to exclaim that the horrific system of the corrupted Revolution be put on trial:

Was it necessary for the safety of France to erase the population within the occidental parts. Was it necessary to the safety of France to make the most beautiful parts of France into a hideous desert. ${ }^{188}$

On veut sauver Carrier can be read as one of the strongest anti-Thermidorian documents written by Babeuf. His litany of the crimes of Carrier serves the purpose of rallying an enraged population against the National Convention. When Babeuf writes that the 'people will not cool to the satisfaction that you [des mânes nombreux 'numerous shades, the dead'] deserve, you will be avenged' ${ }^{189}$ he is not railing
185 Ibid.
186 Ibid.
187 Ibid, 7.
${ }^{188}$ Ibid.
189 Ibid, 9. 
against the Jacobins alone. He states that the removal of Robespierre and the Jacobins

from power is not a sufficient purge of the Convention. When Babeuf asks:

Was it necessary to slaughter 600 infants, or the twenty-three noyades to save the nation? . . Was it necessary for the republican marriages, where the young girls and men, attached nude, were beaten mercilessly with the hilt of sabers and then thrown in the Loire? ... Was it necessary that Carrier slept with three beautiful girls and then throw them into the river? ${ }^{190}$

he is decrying the whole system of depopulation condoned by the National

Convention. Babeuf seems to command that there is a national culpability for the horror of the Vendée. Regardless of the Convention's wish to minimize the guilt to a single individual, Babeuf argues that justice against Carrier alone is injustice for all of France. 'Ah Carrier, Ah Duhem,' Babeuf writes, 'and all you official defenders' of the Convention,

If this is only for you to know how to save the country, then the assassinated nation wakes up before your bloody hands are able to take the final agonizing blow, before your insatiable atrocious hearts have realized your evident wish to enslave humanity in the abyss of destruction, and to rule the cadavers and deserts. ${ }^{191}$

Similarly, Babeuf's words serve to warn two societies when he writes that 'the judgment of the general opinion:'

which has never been pronounced more unanimously against a great culprit, will not fail to call these political dogmas to justice. Nature will not permit, and has never permitted that assassins of the land reap other than the impunity of their barbaric fruits. ${ }^{192}$
${ }^{190}$ Ibid.
${ }^{191}$ Ibid., 12
192 Ibid. 
Though he reviles the crimes of Carrier, he insists that the crimes of the Convention are no less nefarious. Babeuf declares two Convention offenses: the massacres of the Vendée and the execution of Robespierre. It is here, with the trial of Carrier, that Babeuf begins his truce with Jacobinism and the reconstruction of Maxmilien Robespierre. 

measure of religious and classical mythology to color his discourse.

Regardless of the rhetorical style and language of le Tribun $d u$

Peuple, one cannot dismiss Babeuf's words as mythical. According to Robert Darnton, myth making and unmaking were powerful forces in year III and IV. ${ }^{193}$ In the pamphlets produced by Babeuf in the fall of 1794 and early winter $1795,{ }^{194}$ one finds evidence of this mythical dynamism.

When reading these sheets, one is struck by the force of Babeuf's language. These tracts evidence not only Babeuf's definitive re-entry into the Jacobin camp, but

${ }^{193}$ Robert Darnton, The Literary Underground of the Old Régime, (Cambridge Mass and London: Harvard University Press, 1982), 33.

${ }^{194}$ All three pamphlets were published between 17 Brumaire and 15 Frimaire, year II. 
the establishment of a figursit and religious ideology around the entity of Maxmilien Robespierre.

Babeuf had first joined the Thermidorians for reasons of principle. He had, as a prisoner in La Pleiss prison in 1794 regarded the regime of Robespierre as a counterrevolution. Babeuf believed that the Terror had 'robbed the people of its sovereignty.' However, when Babeuf began to see the lack of concern that the Thermidorians showed for the rapidly increasing urban poverty and despair, he relapsed into a Jacobinical radicalism. ${ }^{195}$ By the middle of the Thermidorian reaction, (roughly 3 October 1794) Babeuf had recognized the need for Terror. However, Babeuf wished to infuse Robespierre's system with a different, more egalitarian and republican discourse. The foundation of this discourse is obvious in On veut sauver Carrier. With his modification of Robespierre came a justification of the Terror. The prevailing opinion by the anti-Jacobin press centered on the excess of violence. The press utilized, as its supreme example, the tenure of Carrier in Nantes. The image created by the moderate and conservative press was one of a universal conspiracy against the Revolution in France. Barère, in his Act of Accusation against Carrier, summed up this conspiracy theory when he stated that the Terror was an invention of the coalition of tyrants. These crowned heads of Europe unified with Robespierre, 'the would-be king of the French,' devised the Terror as an institution to 'make the French

${ }^{195}$ Ferenc Fehér, The Frozen Revolution: An Essay on Jacobinism, (Cambridge: University Press, 1987), 124. 
people repent of having desired to open their eyes to enlightenment and pick the fruit of the trees of liberty.' 196 Robespierre, deputy Dupuis continued, 'armed by the crowns of Europe aimed at making this nation of gentle manners revolt from a spectacle of Horrors' 197 and make way for the re-entry of the King. These men attempted to establish the Terror as a royalist plot and thus remove from the Convention and the sitting government any responsibility for the excess of violence. These fanciful accounts explained the crimes of Carrier who, 'under the mask of patriotism, hid the face of an agent of William Pitt. ${ }^{198}$ Babeuf rejected these explanations. Responsibility for the Terror, Babeuf argues, does not lie with Maxmilien the Patriot or with the true principles of Jacobinism. The responsibility fell squarely upon the 'brigands' who had stolen power from the true republicans: Fréron, Tallien, Billaud-Varennes, Barère, Collot d'Herbois, and the other factionalist leaders of Thermidor. Babeuf condemned these deputies for duplicity. The men of Thermidor had used the artifice of republicanism to achieve the heights of power. Once established, they steadily set out to dismantle the very revolutionary structures that had empowered them: the popular societies.

${ }^{196}$ Bertrand Barère, Acte 'accusation contre Carrier présenté aux Comités réunis, à la Convention nationale et au peuple français, Paris, An III, as cited in Bazcko, 180.

${ }^{197}$ Dupuis, Representative of the People, Motifs de l'acte d'accusation contre Carrier, (Paris: III), as cited in Bazcko, 181.

${ }^{198}$ Bazcko, 181. 


\section{Babeuf and the Corrupted Jacobins}

of the Thermidorian regime.

With the fall, it became clear that 'personal rivalries took the place of ideas; the cause of public safety was obscured or concealed by private interest or by personal passions. ${ }^{199}$ In his criticism of corrupted Jacobinism, Babeuf, in his Les Battus payant amende, lambastes the discourses of the 'brigands' who brought down Robespierre as the remnants of the Terrorist regime. Babeuf attacks the remaining Jacobin deputies, such a Fayau and Gaston, as self-interested patriots whose personal fear has crippled their legislative authority. Similarly, Babeuf seeks to discredit those who brought down Robespierre and what Barère had called the 'system of terror.' These men, such as Barère and Fréron, were the very models of the corrupt, yet unpunished, representatives en mission. Bazcko asserts that it was men like Tallien, not Robespierre, whose behavior tainted the Terror. Mathiez argues that the conversion of the ardent terrorist to conspirators was formed by their recall to Paris at Robespierre's behest. ${ }^{200}$ For Babeuf, an explanation of the language of both Fréron and Barère evidences that their anti-Jacobin discourse was truly a product of a personal animosity to Robespierre.

'This jeremiad' writes Babeuf in his Les Battus payant amende about Jacobin turned Thermidorian language, 'is not very intelligible.' In his translation, the Jacobins

${ }^{199}$ Mathiez, After Robespierre, 7.

${ }^{200}$ Bazcko, 49. 
of the Terrorist regime are 'the blood-thirsty,' and the 'furious,' who have 'annihilated the 'mass of men' that prefer justice.' Babeuf blames the Jacobins and their 'dear, barbaric master,' for what he calls 'a deadly reaction,' that has 'in every part of the republic,' resulted in 'tyrannies' by 'all of the little oppressors.' Babeuf writes that corruption has defiled 'their honorable missions [as representatives on mission for the Convention and the Committee for Public Safety] with a zeal that turned revolutionary justice into a slaughter of citizens. ${ }^{201}$

However, the weight of Babeuf's criticism is not lain on the Jacobins, but no the 'little oppressors.' It is the culpability of the Convention, those who destroyed Robespierre but did not dismantle his system that Babeuf attacks as corrupt. The foundation of Les battus payant amende is a criticism of how the discourse of the Thermidorian Convention spoke to the end of the Terror while hypocritically maintaining the dominance of both the Committee of Public Safety and the guillotine. Babeuf criticizes what he calls the 'extractable discourse,' of the Thermidorian remnant of the Terrorist regime. The Les Battus payant amende evidences how, regardless of the fall of Robespierre, the corrupted Jacobins who remaining in power after 9 Thermidor (i.e. Barère, Tallien, Fréron) are unrepentant. Babeuf writes that despite their rhetoric, the Convention makes calls to::

'Maintain the Terror ... . Without it we will perish, and we will be made to answer all the friends of the many French whom we have oppressed, and know that we are repressed by their return and by those innumerable victims who seek vengeance.' 202

\footnotetext{
${ }^{201}$ Babeuf, Les battus payant amende, 4.

202 Ibid., 5.
} 
Babeuf implies that the language of these corrupted Jacobins that advocates the maintenance of the Terror is duplicitous. Babeuf maintains that the continuance of the Terror is not to serve the Republic, but rather to assure the authority of the National Convention. Babeuf's main criticism of this discourse is that it is composed of a language of self-interest and preservation. It is a language that has been corrupted by elitism. It is not a language of a universal republicanism, but of an arrogant Jacobinism that has redefined itself as Thermidorian. He chastises, in his Voyage des jacobins what he calls 'the evangelicals of Robespierre' who:

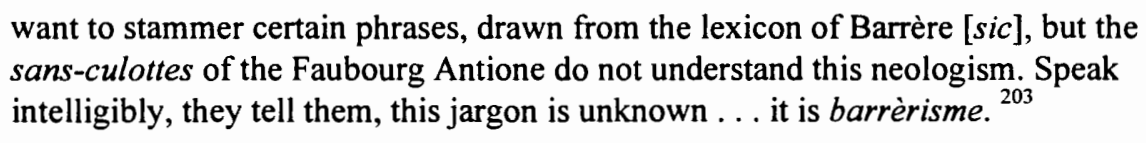

This Jacobin call to maintain the Terror gives tremendous ammunition to Babeuf to both condemn the National Convention and subtly praise the Jacobins. Babeuf argues in Voyage des jacobins that the Thermidorians intended 'not only to maintain' the moral of Robespierre and the Terror, 'but to give it, if it is possible, a greater degree of tension' to free the people 'from its torpor.' This social torpor, Babeuf argues, is the result of the Thermidorian coup-d'etat which removed Robespierre and the Jacobins from power. Having been replaced by 'the aristocracy, (and) the moderates (who have) lifted their heads ... the patriots were oppressed, 204 everywhere in the Republic.

${ }^{203}$ Babeuf, Voyage des jacobins, 9.

${ }^{204}$ Ibid. 
In his Les battus payant amende Babeuf chastises the silent, fearful, and alienated Jacobins who have failed to maintain the most essential social aspects of the Revolutionary government. In his Voyage des jacobins, however, Babeuf attacks the active ex-Jacobins (like Barère, Fréron, and Tallien) as causing a degradation of Revolution. The latter are condemned for destroying the Revolution while the former are chastised for their passivity. Both sets of Jacobins are guilty of corruption and Babeuf lambastes their political language, but defines their crimes and corruption as wholly separate.

Babeuf dismisses the revolutionary rhetoric of both the National Convention and the Jacobin Club as the 'politics of hypocrisy.' The language of both entities is centered on arrogant notions of liberty. Both the Thermidorian Convention and the Jacobins command that liberty is best served by their regime. Babeuf refuses to accept either invocation of 'garnished liberty.' It is Liberty, Babeuf argues, that both triumphed and failed at the end of the Terror. Liberty, Babeuf writes, must be 'given vengeance.' 205

For the Jacobins turned Thermidorians, liberty was corrupted when they dismissed their ideological foundations in 1793. It is liberty that suffers under the hypocrisy of the Thermidorian regime. Babeuf writes that:

If liberty perishes here; our work commands us to die with it. To see your [Thermidorian] self-devotion for liberty, we [Jacobins] can divine that you judge it as 
Mirabeau said, that 'Liberty is a 'bitch' who must choose her lovers from dagger tips. 206

It is not insignificant that Babeuf draws the name of Mirabeau in his condemnation of the Thermidorian regime. Babeuf is attempting to draw a direct reference to the Thermidorians from the breakdown of revolutionary consensus in 1790 and 1791. Mirabeau and the Thermidorian share a common Janus-like duplicity. Babeuf remembers Mirabeau for his ideological betrayal of republicanism to the moderation and monarchy during the National Constituent Assembly. Mirabeau is condemned by Babeuf because he courted liberty and monarchy in order to engender a self-serving form of government. ${ }^{207}$ Babeuf argues that when Mirabeau's moderation replaced republicanism as the his guiding virtue, he became corrupted and his validity as representative of the people was negated. Babeuf casts a similar explanation for the corruption of the Thermidorians. When personal power and tyranny replaced governance and popular sovereignty after 9 Thermidor, the Thermidorians annulled their own claims to representation. Babeuf sees in their language the degradation of the revolution into fixed phrases of 'liberty to oppressed patriots,' and 'Vive la République ${ }^{208}$ instead of social legislation.

206 Ibid, 8.

${ }^{207}$ François Furet, "Miarbeau." A Critical Dictionary of the French Revolution, ed. François Furet and Mona Ozouf, (Cambridge: Harvard University Press, 1989) $: 271$.

208 Ibid., 10. 
Babeuf refers to this Thermidorian rhetoric as 'an ingenious diversion.' The language of the Convention, however, presents an image of a patriot who:

promenades the bonnet of liberty at the top of a pique with a new cry : Vive la Répubique, Vive la Convention! ${ }^{209}$

but serves only his own self-interest.

What Babeuf sees in this discourse is a futility of words. The verbal maneuvers does not divert or ameliorate the enemies of the Republic. Rather, Babeuf argues that the Thermidorian language is filled 'the fire of courage (that) animates' their speech, but 'does not say anything grand.'

Babeuf, however, insists that the discourse of Jacobinism under the Thermidorians is no better. This language, Babeuf writes, is one of resignation. In a statement that Babeuf represents as both futile and valiant, the Jacobin language is epitomized by:

Let us die, it is necessary, but let us have the courage of liberty until the final moment. ${ }^{210}$

However, Babeuf continues to write that 'these ridiculous and bumbling false feats' did not save or convert anyone to the Jacobin cause. 'The evangelicals of Robespierre' Babeuf writes, failed to secure their authority because they 'sermonized in the home' in which they alone had come to preach. ${ }^{211}$ The Jacobins had attempted to make their

209 Ibid.

${ }^{210}$ Babeuf, Les battus payant amende, 10.

211 Babeuf, Voyage des jacobins, 11. 
own language the only sound heard throughout the nation. They were amazed, Babeuf argues, when the response was a resilient silence. The rampant abuse of authority had alienated the Jacobins from France. The result, Babeuf comments, is that for the Jacobins:

Every prestige was reduced to folly because the 'brigands' of 9 Thermidor were the masters of the house. ${ }^{212}$

Babeuf makes a very clear and overt attack on the Thermidorian regime in Les Battus payant amende by writing 'I can no longer abide Fréron.' It is here, within this reproach of Fréron, that Babeuf moves from an examination of a failed discourse into a use of revolutionary and denunciatory rhetoric.

Babeuf states that 'since 9 Thermidor, they [the Thermidorians] have said not one word about rights.' As the Thermidorian reaction continued, Babeuf steadily realized that the words of Barère, who claimed that the fall of Robespierre was only a 'slight commotion which left the government intact, ${ }^{213}$ had become increasingly true. The Revolutionary government had not been dismantled. France, Babeuf writes, had only switched chiefs. The new chief no less a tyrant, only less revolutionary.

From this realization Babeuf penned his argument that if Fréron were to be 'stricken from the society of Thermidor' it would 'only give it more honor.' The sin of

${ }^{212}$ Babeuf, Les battus payant amende, 14.

${ }^{213}$ Woronoff, The Thermidorian regime and the Directory 1794-1799, 1. 
Fréron, Babeuf writes, was that he had falsely presented himself as a 'Orator of the

People', as a mouthpiece to pronounce their sentiments and rights. Fréron, however:

Appearing only to put to his mouth the trumpet of journalism to raise the pack of Jacobinism's enemies had only placed it there to avenge his own personal cause. ${ }^{214}$

Les battus pavant amende and Voyage des jacobins:

The Discourse on Popular Societies

Babeuf expends considerable energy within these pamphlets examining and presenting the hypocrisy of Thermidorian language and politics. Nowhere is this hypocrisy in language and politics more evident than in the Thermidorian discourses on Jacobins and on popular societies. Babeuf writes, in Voyage des jacobins that 'democratic government cannot save itself without popular societies.' Wherever people are free,

Babeuf continues:

there is a forum, assemblies of the people where it is possible to listen, discuss and examine the affairs of our political administration. Without them, without these meeting points, it appears that the conducting of the government will be entirely at the mercy of the governing, and that ... (this will result in the) ... opening of all manners of censorship ... the absolute domination of the citizens (by) all the species of abuse ... ${ }^{215}$

The foundation of this Babouvist press is summed up in Les battus payant amende when Babeuf writes that the premise and principles of the Jacobins themselves, regardless of their ultimate corruption, are just and righteous. 'Who

${ }^{214}$ Babeuf, Les battus payant amende, 19.

${ }^{215}$ Babeuf, Voyage des jacobins, 10. 
doubts that the sénat ${ }^{216}$ is disposed and driven towards the dissolution of the Jacobins? . . Was it not positively from this point that the jacobite society would attain this decadence in its final hours? ${ }^{, 217}$ Babeuf, as well, chastises the Convention for its asinine proposition to close the Jacobin Club and all popular societies for their complicity in the Terror. For Babeuf there is no way to separate the Thermidorian

Convention from the Terror. 'I have said it,' he writes in Voyage des jacobins:

all is plain, Robespierre has been put in all the administrations, all the revolutionary committees, in all the military and civil agencies... ${ }^{218}$

Though popular societies 'received their guarantee of existence from the Declaration of the Rights of Man and Citizen and from the Constitution' Babeuf warns in his Voyage des jacobins that popular societies, like freedom of the press, are sustainable only in an uncorrupted and pristine form:

One may abuse the best thing, as we have seen (in the Jacobins), and it has been a method to make counter-revolution with the Declaration of the Rights of Man and Citizen whose sacred principles of 'resistance to oppression' is perchance to be invoked 'à tort-à-travers' ... One must regard these two things before employing; otherwise one may fall into abuse, and put in its place resistance to justice. ${ }^{219}$

${ }^{216}$ Babeuf uses the term Sénat interchangably with National Convention. It would appear by an analysis of usage that Babeuf considered sénat pejorative and insulting. He only uses the term in sentences where he casts doubts about the legitimacy of the National Convention to act as representative of the French people.

${ }^{217}$ Babeuf, Les battus payant amende, 18.

${ }^{218}$ Babeuf, Voyage des jacobins, 9.

${ }^{219}$ Ibid., 7. 
The meaning of this statement is obvious. In the dualistic system of Babeuf, it is the presence of Robespierre the Tyrant that has corrupted the institutions of the regime. Babeuf is not merely stating that the Terror has allowed the Thermidorian regime to deny the validity of the popular societies. Babeuf argues that the Convention itself, like the popular societies has been tainted by tyranny.

Babeuf explicates this paradox between the pure and the polluted forms of sovereignty in his Les battus payant amende. He writes that though 'public safety is the supreme law' the closure of the Jacobins is cannot be justified only by their 'having become depraved and dangerous, and menacing' and the danger that they would become 'next explosive and disastrous' to the Republic. ${ }^{220}$ However, the logical conclusion of the arguments presented by Babeuf in both Voyage des jacobins and Les battus payant amende is that if the Jacobins should be dispersed for their role in the Terror, then the National Convention itself should be disbanded for its criminality.

Babeuf's Les battus payant amende is a fascinating pamphlet because of this justification of popular societies. It follows an extremely narrow path of a simultaneous exaltation popular societies and condemnation of the National Convention. 'I have faith,' he writes, 'and it is not only here that I will declare against the sénat when, in heavy consideration of these circumstances, (the closure of the

${ }^{220}$ Babeuf, Les battus payant amende, 18. 
popular societies) I recognize that it was the sénat who had taken these great measures' against 'a useful and well instituted machine.' However, he continues that:

In effect, with regard to the particulars of the Jacobin society, I think it possible to prove clearly that it had contracted a sectarian spirit that would only render it dangerous and not at all useful. ${ }^{221}$

However, in a passage that is written solely for the benefit of the Jacobins, Babeuf resurrects the name of Robespierre. Babeuf quotes of the Robespierre to evidence the predicted deviation of the Jacobins. Babeuf writes that:

Robespierre, its founder, had pronounced his sentence in terms that we are able to suspect of having been only the correct view. He had written in the month of June 1792, page 236 of the Défenseur de la Constitution, these words : 'The popular societies are lost, from this point forward they will become a resource of ambition and intrigue.' 222

Babeuf seems to present this quotation as evidence that the corruption of the Jacobins, and indeed of Robespierre himself, was forecasted before the reign of Terror.

Babeuf utilizes this style of quotation to further differentiate between the two entities of Robespierre. He purposefully casts a diametrically opposed version of Robespierre. Babeuf establishes that Robespierre, like the Jacobins, becomes a character whose fall from grace was tragic, and whose attempt to maintain authority was evidenced his ultimate corruption.

Babeuf presents his Les battus payant amende in order 'to resolve, to read seriously the morality' of the Jacobin Society. Babeuf realizes that 'I will not find the
221 Ibid., 7.
222 Ibid., 13. 
whole world pleased by this history' of the Jacobins. This history, Babeuf writes, is not a history of the society. Nor is this pamphlet a work to discredit the popular societies of the Revolution. It is written to show how the Jacobin Society became corrupted. Les battus payant amende is written:

only in regards to individuals; not to the principles. One distinguishes carefully these two objects. We are entertained by individual (Jacobins): but we reclaim and defend courageously the principles... We have said that it (the pamphlet) is only laughing at the Jacobins, and at their misadventures. However, maybe the principles raped by their corruption will become seriously declared again(with a faith-like loyalty). ${ }^{223}$

Babeuf asserts that the corruption of the Jacobins resulted from their betrayal of democracy. He states in Les battus payant amende that the final meeting of the Jacobin Club was a final attempt to 'return to the banner of democracy.' However, Babeuf rails that the arrogance of the Jacobins to maintain their own power would not allow a reunion of the Republic. Babeuf states that the:

moment where the storm broke was precisely that, where Lanot gives a repetition of the verse so hackneyed: 'that patriotism is attacked today by the aristocracy ... (that) After the fall of Robespierre, it has been, in all parts of the Republic, a profound reaction, and the patriots have been persecuted. ${ }^{224}$

In one of his most moving and proverbial denunciations of the Jacobins, Babeuf writes that 'the titans appeared unchained at the same instant (as the Jacobin Lanot began to speak) to punish the insults of the gods and men. ${ }^{225}$ The simple beauty of this attack is its classical imagery. Babeuf implies that the Jacobins were

$$
\begin{aligned}
& { }^{223} \text { Ibid. } \\
& { }^{224} \text { Ibid., } 4 . \\
& { }^{225} \text { Ibid., } 5 .
\end{aligned}
$$


destroyed by their own vanquished past. The imagery of Greek Gods, sitting arrogantly upon Mount Olympus, attacked and punished by the Titans, the ancestors of Zeus, defines the corruption of the Jacobins. The Titans appear as the pristine philosophy of 1789 insulted by the tyranny of 1794 . Thus, Babeuf asserts that the speech by Lanot declared the degradation of the Jacobins. Even in the moment of defeat, the Jacobins attempted to rally, not to the Republic, but to the memory of Robespierre the Tyrant. Lanot proves to Babeuf that the fundamental Jacobin philosophy that had raised and saved the Republic in 1792 had been corrupted by power and prestige by 1794 .

Having been corrupted, the Jacobins further distanced themselves from their philosophical foundation with their rebellion against Robespierre on 9 Thermidor. Babeuf writes that the condemnation of the popular society in the months after the fall was revenge for the corrupted Jacobinical duplicity. Babeuf writes the Jacobins responded after 9 Thermidor by attempting again to distance themselves from their own history. Once the hold of the Thermidorian regime became violently known to the Jacobins, they, like Babeuf, sought to re-align themselves to the image of their slain leader. Babeuf writes that the Jacobin excuse for their duplicity is, however, mythical:

After having declared open revolt in the evening of 9-10 Thermidor, to escape the chastisement due for this complicity, the society writhed jesuitly ${ }^{226}$ under their poor excuse that it was not the society at all that had rebelled during that night, but rather that brigands who, like Goai of the fable, had donned their feathers, and having, by

${ }^{226}$ This use of of the word 'Jesuit' is fascinating. It is one of the few obvious modern religious allusions. It also serves to lay a greater foundation for the Jansenist influences on Babeuf. 
an amazing and ingenious metamorphosis ... dressed in the costume, borrowed the figure, the gesture, the voice, the spirit and the eloquence, pilfered the keys of the location, and took control of the handball, societal peace; those who, in that moment, were one would not know, and that had never dreamt of reassembling again ${ }^{227}$

This use of fable strengthens Babeuf's image of a beaten, betrayed people fills Babeuf's Les battus payant amende. In Les battus payant amende, Babeuf writes of the final gathering of the Jacobins and presents an historic version of the attack of the Jeunesse dorée on the Jacobin Club on 19 Brumaire as the final outrage of a desperate, yet remarkably redeemable sect:

One is certainly not more brave ... they [the Jacobins] were in a closed and shut place; the aggressors [Jeunesse dorée], however, had the advantage of the open space ... The society sent auxiliary light infantry to ascertain the force of the enemy, to establish its dispositions; but these observers had the imprudence to engage in some skirmish ... there were disorders and mix-ups ... soon the besiegers obtained a decisive advantage. They had the battlefield and the accessories. Walls and tribunes, these were at their disposal. ${ }^{228}$

Babeuf is, however, unable to condemn the society. The foundation, the base, and the roots of the society are pure. It is growth, limbs, and branches of the Jacobins that have been perverted. What is fascinating about this episode is the method by which it is presented. Babeuf is recounting the final assault of the Jacobin Club by the Jeunesse dorée, and yet he relates it as an episode of Roman history. It appears that Babeuf, by distancing the facts to an historical episode in Rome, intends Les battus payant amende as a universal parable. What is not obvious is whether this parable is intended

${ }^{227}$ Ibid., 14.

${ }^{228}$ Babeuf, Les battus payant amende, 11. 
to be read as an historical justification for the corruption of the Jacobins, or for their redemption.

It is obvious that Babeuf sees valor in the Jacobins. His description of the gilded youth as 'aggressors' is pejorative. However, Babeuf also equates the Jacobins as treasonous. The one instance within this polemic that virtue is obvious is in the Jacobin wives of who defend the principles of the society:

\begin{abstract}
The citizen Crassous, wife of the president of the same name, and with her the other heroines of the natural blood who had reasoned from the wrathful patriotism, who had available only five or six precious words to constitute the code of Terror, who had a thousand times the virtue of Cornélie with whom I have already said that I am not at angered to see our women act in the interest of public affairs; the citizen Crassous, I said, and certain of her companions, were before the close of the honest castigation. The ceremony completed, each laid low. ${ }^{229}$
\end{abstract}

However, the language of this tale presents a hope of reconciliation. Babeuf utilizes the action of the heroic Republican women in opposition to the vanity and arrogance of the men. This is a language of sexual equality. Babeuf's discourse invests purity, virtue, and redemption in women. Babeuf provides a significant political power to females. This discourse fits easily into Babeuf's general theme of corruption and grace. Women, having been removed from both active roles as revolutionaries and members of popular societies, remained untainted by the baseness of the reign of Terror. Therefore, whatever purity that could be wrested from the popular societies would be found in the active role of women. This notion of female political activity is ${ }^{229}$ Ibid. 
one of the few constants within the revolutionary discourses of Babeuf. From 1789 forward, Babeuf was an active, albeit unsuccessful, champion for the 'l'egalité réele' that would assure an equal legal status for all citizens, regardless of sex. ${ }^{230}$

It seems ironic, in a political sense, that the Thermidorian regime attempted to silence the popular societies. The popular societies had been indispensable in the overthrow of the Terror. A month before the fall of Robespierre, Legray and the Museum section, began to lobby the Convention for the restoration of the electoral principle. In the months that immediately followed 9 Thermidor, popular societies acted in cohesion with the Thermidorian rhetoric of elections and democracy. However, it was the vocal and popular nature of these societies that frightened the Convention. As the months of August and September passed without significant alteration in either the political composition of the National Convention or the dismantling of the Terror, the popular societies began to call for new popular measures. Varlet, a firebrand and notorious enragé who had remarkably survived both the Terror and 9 Thermidor, began, in the beginning of October 1794 to agitate for elections. $^{231}$

Varlet joined with both Legray and Babeuf in creating the Electoral Club as venue to voice the general will of the people. This popular movement did not exist in

${ }^{230}$ F.-N. 'Gracchus' Babeuf, Le Tribun du Peuple, (Paris: R. Lebois, Imprimerie de l'Ami du Peuple, 1796), 1.

${ }^{231}$ R.B. Rose, The Enragés: Socialists of the French Revolution? (Melbourne: University Press, 1965), 31. 
the early Fall. The Electoral Club grew in the winter as Babeuf began to re-examine his pernicious attacks on Robespierre. The Club was justified as a response to the authority and power of the anti-democratic regime. According to Babeuf, the majority of the Electoral Club was comprised of 'la jalousie des Jacobins.' ${ }^{232}$ These irreconcilable Jacobins took refuge with the increasingly radical and republican discourses of Babeuf.

At the dawn of the Thermidorian reaction, many of the Hébertists and members of the Electoral Club rushed to embrace a promise of new economic liberty. Their belief was that a removal of the maximum would allow for the increase of wages and living standards in France. There was a general call by the deputies and men of commerce against the economic restrictions imposed by Robespierre. In a speech on the 3rd sans-culottide, Dubois-Crancé stated that it was the imperative of the regime to create a 'political pacification' that would revive commerce, agriculture, and industry:

On all sides commerce is annihilated, for any man who set money in circulation was suspected and accused of profiteering. . . It was no longer the aristocrats who were being persecuted; it was the rich who were being plundered and massacred under the name of aristocrats, all those who had set in movement the talents and industry of the people. . . The fortune of one million men in France fosters the industry of twentyfive million others. ${ }^{233}$

Babeuf appears to have been the sole opponent to this idea. Babeuf alone grasped how desperate and deep the abyss of poverty had grown for the poor. ${ }^{234}$ Babeuf's concept

${ }^{232}$ Tønnesson, La Défaite des sans-culottes, 57.

${ }^{233}$ Bazcko, 158.

${ }^{234}$ Ibid. 
of the Electoral Club was one in which the people, having lost their voice within the increasingly moderate and aristocratic National Convention, would be able to exert an influence over the policies of the government in the tradition of Hébert and Marat.

However, the critical words, calls for both elections and the institution of the Constitution of 1793, when combined with Babeuf's reinvention of Maxmilien the Patriot, won the Electoral Club the reproach of the deputies of the Thermidorian Convention. The political power of this popular society was proclaimed when the Committee of General Security declared the Electoral Club subversive. The Convention assumed that the Electoral Club was an instrument of the resistance to the moderates and the deputies of the right. In the wake of the Club's denunciation by the Convention, Babeuf penned the Voyage des jacobins as polemic decrying the illegal closure of the Jacobins and as a verbal demand for justice for the Electoral Club. Babeuf writes that the Electoral Club had been oppressed by the Thermidorian regime 'because of journalists who had made the voyage from the Jacobins to the Electoral Club. The moderates reacted to this journalistic desertion by creating plots and conspiracies, 'invented, no doubt by those who are happy to profit from the circumstances to throw out all the popular societies.' The expulsion of the popular societies, Babeuf continues, has left the governance of France in the hands of: those men who have baptised in the red waters [noyades ${ }^{235}$ ], these demons aspire to become the purifiers of the French people.

${ }^{235}$ Noyades is the term employed by the French to describe the mass drownings of priests and clergy during Carrier's pacification of the Vendée. 
There is a striking use of language in this tract. While commenting on the necessary role of the popular societies, Babeuf reverts to a discourse with a specific religious meaning. Babeuf utilizes words such as baptism, demons, and purifiers. Though intended to support the Electoral Club, this pamphlet can also be read as turning point in the reconstitution of the political ideology of Babeuf. In the pages of Les battus payant amende, Voyage des jacobins, and On veut sauver Carrier Babeuf not only begins to revisit the pure forms of the Jacobins and Robespierre, he also begins to conceive of Robespierre as a religious figure. 
Figurism and Babeuf's Language on Civil Religion:

Robespierre, L' Etre Supreme, and Cercle Social.

With the change in Babeuf's discourse came the re-invention of Robespierre. Babeuf was convinced that he had found in Robespierre an ally guided by the same ideology. ${ }^{236}$ From November 1794, Robespierre was divided into two separate entities. Robespierre the Tyrant and Maxmilien the Patriot. Frenc Fehér describes this stylistic evolution as a philosophic metamorphosis. Fehér argues that Babeuf revisited the icon of Robespierre when Babeuf began to perceive Robespierre as his own eminent precursor. ${ }^{237}$ Babeuf saw Robespierre as l'illustre martyr de la liberté who paved the way for Babeuf's social revolution.

It is evident that Babeuf in 1794, two years before his arrest for conspiracy, was committed to the Robespierrist notion of revolution. Ironically, for all the criticism that Babeuf cast upon the corrupt regime of Robespierre the tyrant, Babeuf seems to have believed that the Jacobin dictatorship was the sole model for revolution. His discourse did not attempt to substantively change the Robespierrist revolution.

When his conflict with the Thermidorians grew into an outright battle in December 1794 and January 1795, Babeuf did not attempt raise himself or his discourse from the assumed value and master narrative of the Terror. In the course of a

${ }^{236}$ Daline, "Robespierre et Danton vus par Babeuf.": 393.

${ }^{237}$ Ibid., 130. 
few weeks, from 23 September to 25 October, Babeuf recast himself from the language of 'vehement anti-Jacobin' into what Fehér calls the 'super-Jacobin.'

Fehér argues that Babeuf fell immediately back upon Robespierre because he was unable to conceive of any other 'paradigm of revolutionary action. ${ }^{238}$ There is, however, another philosophy at work. It can be argued that Babeuf's re-conversion to Jacobinism is based on a theological paradigm. It is within this evolution and reexamination of Robespierre and the Jacobins that Babeuf gives rise to a philosophy of figurism. ${ }^{239}$

In both Les battus payant amende and Voyage des jacobins the language of corruption and redemption is obvious. The division of Robespierre and the Jacobins into separate and distinctive entities, that of virtue and that of corruption, is a political parallel to the religious ideology of Jansenism. As Jansenism saw their persecution in the 1750s as an era of 'prophesied trouble, obscurity, and defection by the "Gentiles",240 so Babeuf saw the corruption and closure of the Jacobins from 1793-94 as a predicted apostasy.

${ }^{238}$ Ibid., 147.

${ }^{239}$ According to Van Kley, 'figurism' was redefined by the Jansenists as an era of apostasy when the true path to salvation would be obscurred by a corruption of the majority of believers. Figurism advocates that while defection would result in a great crisis and persecution, that the true faith would retain a few uncorrupted voices who would remain faithful. (Van Kley, 92).

${ }^{240}$ Dale Van Kley, The Religious Origins of the French Revolution. From Calvin to the Civil Constitution: 1560-1791, (New have and London: Yale University Press, 1996), 92. 
The philosophy engendered by Babeuf in November 1794 , as shown in Les battus payant amende, On veut sauver Carrier and Voyage des jacobins is ultimately one of grace. The figures of Robespierre and the Jacobins show the catastrophic fall from grace envisioned by the Holy Scripture. ${ }^{241}$ Babeuf began to conceive of himself as the embodiment of an uncorrupted Jacobinism.

The effect of figurism is evident in the language of the opening paragraphs of Babeuf's Voyage des jacobins. Voyage des jacobins presents the most complex and image rich language of all his writings. Based loosely on the Acts of the Apostles, Babeuf attempts to establish a religious discourse on the future of the Jacobins. Babeuf writes 'Go to all the world, preach the gospel and instruct all the people, baptize them in the name of the invincible trinity. ${ }^{242}$ These are the instructions that Babeuf, following chapter fifteen of St. Paul's letter to the Corinthians, gives in his Voyage des jacobins. "Go to all lands and preach fraternity or death, and instruct the nations, and initiate them into the cult of the Supreme Being. ${ }^{243}$ Babeuf creates an imagery that is undeniably religious:

One is assured that the last mission of this delegation parallels absolutely that of Christ's disciples. . . the colony of Jacobins is going to disperse itself into the two hemispheres, and undertake the foundation of the Universal church, cemented, like

${ }^{241}$ Van Kley (92) attributes the Biblical foundation to Figurism to the eleventh chapter of Paul's epistle to the Romans.

${ }^{242}$ Babeuf, Voyage des jacobins, 2. Babeuf's use of the trinity has two possible meaning. With his re-examination of Jacobinism, he may use the term trinity to refer to the executed triumphers of Robespierre, Saint-Just, and Couthon. However, what is more likely is that Babeuf intends trinity to be be read as Liberté, Egalité, et Fraternité.

${ }^{243}$ Ibid., 3. 
that which is sacred in Rome, with the blood of its martyrs and that of its victims ... Let us begin, (it says) by taking the word of the Supreme Being to the department of the blind: they will become the easiest to convert, and when we have them, we will be stronger in gaining the others. ${ }^{244}$

This pamphlet is fascinating because of the method and language by which Babeuf delivers his message. The pamphlet is conceived as a conversation between Babeuf and an anonymous Jacobin. Through this verbal intercourse there evolves a vision of a Robespierre who has transcended his Jacobin origins. Babeuf and the Jacobin both advocate the imitation of Robespierre. However, both Babeuf and the Jacobin state strikingly separate reasons. The Jacobin presents a dogmatic and traditional set of reasoning. Babeuf, however, states that the new patriots do not 'want to become men of blood (like the Jacobins).' He distances his new message by saying 'we do not want the death of the preacher, [a direct reference to justice under the Terror] but only that he is converted, 245

How does Babeuf intend to convert? He writes that if the republicans intend to use the prior methods of forced conversion that they will 'convert no one.' Instead, Babeuf implores, 'listen, we will profess the doctrine of the Rights of Man:

Bravo, bravo, respond the Maxmilienistes, this [the Rights of Man] is also our religion; we have had several signs in advance that you and we will follow the same articles of faith [the doctrines of Jacobinism], also that we have not come with the intention to proselytize; but to Fraternize only. Therefore, they confound an alliance of force ... We propose to you ... a an article of the declaration of right. It is this here: 'When the government violates the rights of the people, insurrections is for the

244 Ibid.

245 Ibid., 4. 
people, and for every portion of the people, the most sacred of rights, and the most indispensible of works. ${ }^{246}$

It is at this portion of the pamphlet that the discourse of Robespierre assumes a far more sacred tone. Babeuf begins to compare 'Jesus the Crucified to Maxmilien the beheaded (décollé).' Babeuf writes:

The Nazarene descended in the sign of fiery languages, a visible symbol of the flame of his doctrine that will illuminate the universe. The artisan, then, must descend equally into his spirit, but in languages of the guillotine, the projectiles of a cannon. . . the wick of the explosive, images telling the diverse and destroying manner already used by the religion of blood to affirm their institution. ${ }^{247}$

Babeuf continues to write that 'Jesus and Maxmilien speak equally' to the Jacobins.

Both Christ and Robespierre give the same advice: 'Do not reject the bad treatment of men: when one chases you into a corner, you will retire into another, ${ }^{248}$ From this, Babeuf writes that as Jesus gave the command to commence the 'preparation for Jerusalem, and go quickly to where my spirit drives you, without bringing any inquietude, my father will take care of your nutrition ... I will give you languages and miracles' ${ }^{249}$ so did Robespierre's command declare:

Begin by motioning in the Jacobin Society, and then go quickly straight without your shirt and without bringing your substances, the Supreme Being will provide, and better still, the right of requisition on the peoples and properties, I invest you in his name (Supreme Being) du Rhin l'Océan et des Pyrênees au Nord, as well as all the other revolutionary principalities, whom you will control prodigiously, and be heard equally du Chouan et de l'Allobroge, du demi-Castillan et de l'Alsacien. ${ }^{250}$

246 Ibid.

247 Ibid., 5.

248 Ibid.

249 Ibid., 6.

250 Ibid., 5. 
Thus indoctrinated and, as Babeuf writes, 'full of the revolutionary confidence of their master' the inspired troop of Jacobins disband to commence their 'missionization from Paris. ${ }^{251}$ The reason for this need to evangelize lies in closure of the Jacobin Club. As soon as the Thermidorian Convention had locked the doors to the hall, Babeuf writes:

\begin{abstract}
A shower of stone fell within the old sacred walls. The earth trembled, the sun became obscure, the vault of the temple was torn in two, the hearts burst asunder, and the devotes of the Grand Maxmilien believed to see the Anti-Christ. They implored the Supreme Being, but it was deaf to their calls. 'To the base of the Jacobins' cried the envoys of God or the Devil, we do not know which it was; but always they were armed with clubs and other frightful instruments. ${ }^{252}$
\end{abstract}

The Convention, Babeuf argues, did not and could not destroy the principles of Jacobinism. Thermidor, despite it vicious attacks, produced as surprising reaction towards the philosophy that it sought to destroy. It is amazing that the Thermidorian political discourse could facilitate the transference of Babeuf's language from 'Robespierre the tyrant' to 'Maxmilien the Patriot.' It is even more tremendous that it was during Thermidor that Babeuf began to conceive of Robespierre as the manifest icon of the Supreme Being.

It is interesting that revolutionary language, until the last months of the Terror, remained resolutely secular in content. The rejection of Christian and Catholic vocabulary was a method by which revolutionaries had announced their break with the

${ }^{251}$ Ibid.

${ }^{252}$ Ibid., 6. 
past. The old religion had passed with the ancien régime. It became necessary, as the Revolution progressed, to give 'a concrete and organic form to the spiritual ideals' of the Revolution. ${ }^{253}$

The role of religion within the final months of the Terror must be seen in response to Vadier, the deputy who embodied the anticlericalism of the Committee of General Security. He ridiculed Robespierre and discredited the Cult of the Supreme Being as aspects of a greater Robespierrist policy of religious appeasement. ${ }^{254}$ From 18 Floréal onward, Vadier opposed Robespierre's recognition of the existence of God.

Vadier resented Robespierre's new role as the Pontiff and sought to destroy Robespierre before the vision of Théot ${ }^{255}$ came to fruition. Vadier summarized his opposition to the religious warming by saying:

La Saint Barthélémy, les vêpres siciliennes, la conspiration des poudres, les auto-dafés et tants d'autres horreurs religieuses qui ont abreuvé la terre de sang humain pendant dix-huit siecles, ont pris leur source dans l'âme depravée des prêtres . . . c'est avec les promesses de paradis et les menaces de l'enfer que ces hommes foubres ont dingé le fer et le poison au gré de leur vengeance et de leur ambition criminelle. ${ }^{256}$

Vadier's condemnation sought to do three things: to attack religion, link religion with the fear of counter-Revolution, and link both religion and counter-Revolution to the

${ }^{253}$ Dawson, Gods of the French Revolution, 102.

${ }^{254}$ Martyn Lyons, "M.G.A.-Vadier (1736-1828) The Formation of the Jacobin Mentality." in French Historical Studies, Vol. 10, no. 1, Fall (1977) : 75.

${ }^{255} \mathrm{Mme}$. Théot was a religious mystic who had visions of the creation of a new French Church. Her prophises of Robespierre becoming 'a second-coming of Christ'were used as a justification in the overthrow of Robespierre.

${ }^{256}$ Lyons, "V.G.A. Vadier.": 95. 
tyranny of Robespierre. Vadier wounded Robespierre's credibility as the High Priest of the Cult of the Supreme Being. ${ }^{257}$

Vadier's opposition lies at the heart of Montagnard opposition to Robespierre. The radicals saw Robespierre's religious appeasement as a surrender to counterRevolution. However, Robespierre was not alone in his belief that religion was an essential component to republican virtue. A.-J.-B. Guffroy adamantly supported the religious politics of Robespierre. In Floréal, year II, Guffroy composed much of his journal around the support of the creation of cult of the Etre Suprême. In his issue of 24 Floréal, Guffroy writes:

Les Français régénérés ne cessent de sonner le reveil des vertus, l'agonie des vices et le trépas du crime. C'est dans la Convention nationale, c'est aux jacobins, c'est dans les Sociétés populaires, et dans les séances publiques des tribunaux et des corps administratives qu'il faut voir des Français. C'est là que se fait journellement ce commerce de vertus qui doit achever la régénération française, et assoir la République sur une base immortelle. ${ }^{258}$

Many republicans, from Guffroy to Jacques Roux to Babeuf detested atheism as a heresy of elitism and privilege. ${ }^{259}$ Robespierre is quoted as saying the 'Atheism is aristocratic ... the idea of a supreme Being who watches over oppressed innocence and punishes triumphant crime is entirely democratic. ${ }^{260}$ For Robespierre:

anything that is of practical utility to the world is true. The idea of the Supreme Being and the immortality of the soul is a continual reminder of justice: therefore it is social and republican. ${ }^{261}$

257 Ibid.

258 Aulard, "Babeuf et son imprimerie Guffroy.": 22.

259 Rose, Enrages, 42.

${ }^{260}$ Dawson, Gods of the Revolution, 113.

${ }^{261}$ Ibid., 125. 
Robespierre and the radical republicans saw no difficulty in reconciling a version of reformed Christianity with the revolutionary cult of patrie and raison. The language of Christianity had only to be transcribed into a revolutionary rhetoric.

Alphonse Aulard presents, in Christianity and the French Revolution, evidence on

how revolutionaries intended to utilize the origins of Christianity to serve the needs of the Revolution:

\begin{abstract}
How was the Christian religion established? By preaching of the apostles of the Gospel. How can we firmly establish the Constitution? By mission of the apostles of liberty and equality. Each society should take charge of the neighboring country districts ... It is enough to send an enlightened and zealous patriot with instructions which he will adapt to the locality: he should also provide himself with a copy of the Declaration of Rights, the Constitution, the Almanack du Père Gérard, a good tract against fanaticism, a good journal and a good model of a pike. ${ }^{262}$
\end{abstract}

With the support of moderate and radical deputies, Robespierre decreed on 18 Floréal, year II, the Worship of the Supreme Being. In his speech Robespierre established that:

(1) The French people recognizes the existence of the Supreme Being and the immortality of the soul; (2) [The people] declare that the best service of the Supreme Being is the practice of the duties of man; (3) In the first rank of those duties [the people] place hatred of treachery and tyranny, the punishment of tyrants and traitors, succor of the unfortunate, respect for the weak, defense of the oppressed, doing all the good one can and not being unjust to anyone. ${ }^{263}$

Though acceptance of the decree was not universal, the cult of the Supreme Being was praised by representative on the Revolutionary Committees and deputies National

${ }^{262}$ Aulard, Christianity and the French Revolution, 74.

263 Ibid., 127. 
Convention. Jullien, ${ }^{264}$ a member of the Committee of Public Instruction, spoke that religious sentiment was the soul of patriotism. The deputy Marie-Joseph Chérier writes that with the invocation of the new religion he hoped to:

$[\mathrm{W}] \mathrm{rench}$ the sons of the Republic from the yoke of theocracy which now weighs upon them . . . then, freed from the prejudice and worthy to represent the French nation, you will be able, on the ruins of fallen superstitions, to found the one universal religion, which has neither secrets nor mysteries, whose one dogma is equality, whose orators are the laws, whose pontiffs are the magistrates, which asks no incense from the great human family to burn save before the alter of our country, out mother, and our deity. ${ }^{265}$

For Robespierre, as well as William Blake and Thomas Paine, the Revolution was 'no mere political event' but a crises which would announce 'the birth of a new moral world and the regeneration of humanity. ${ }^{266}$ The creation of the Supreme Being, then, assured that the new moral order would be coupled with a pure religious form.

Babeuf, in refashioning Robespierre under the Thermidorians, promoted Jacobinism as a religion of human salvation. It embodied the salvation of the world by the power of man set free by Reason. 'The cross has been replaced by the tree of liberty,' Dawson writes, 'the grace of God by the reason of man, and redemption by

${ }^{264}$ Jullien would later distinguish himself as one of the supposed 'Conspirators for Equality' with Babeuf.

265 Aulard, Christianity and the French Revolution, 134.

${ }^{266}$ Dawson, Gods of the Revolution, 103. 
Revolution. ${ }^{267}$ This quote shows that just as the revolutionaries had sacralized and moralized politics, they politicized religion. ${ }^{268}$

The Revolution co-opted the discourses of religion to suit the desires of the revolutionaries. Susan Desan argues that the revolutionary leadership had created a whole 'cultural system of revolutionary rituals, symbols, and language that aimed at replacing Christianity.' The ultimate desire of this creation was to offer a redemption to people 'according to the political ideals of the Revolution.' Robespierre, Babeuf, and other radical revolutionaries had come to view Christianity, Desan argues, 'as the rival cosmological and moral system that had provided the frame and underpinning of the monarchy and the traditional hierarchical order.' 269

What commenced, however, was a conflict over the role of religion within a republic. The religious conflict of 1794 , it has been argued by Christopher Dawson, was due not the inherent conflict of atheism and theism, but rather between the 'negative deist rationalism' of Voltaire (which condemned Christianity) and the 'mystical deism of Rousseau' which embodied the need to mend the form Christianity into a civic religion. ${ }^{270}$

${ }^{267}$ Aulard, Christianity and the French Revolution, 74.

${ }^{268}$ Suzanne Desan, "Redefining Revolutionary Liberty: The Rhetoric of Religious Revival during the French Revolution." The Rise and Fall of the French Revolution, ed William Blanning, (Chicago: University Press, 1989): 362.

${ }^{269}$ Desan, "Redefining Revolutionary Liberty." 361.

${ }^{270}$ Dawson, 102. 
Filippo Buonarotti, the first biographer of Babeuf, described the religious conflict as debate the order of egotism and the order of equality. The rationalist, antiChristian attitude of Voltaire (egotism) corresponded with the bourgeois liberalism of the Constituent Assembly. Within this paradigm, the Thermidorian regime welcomed the Revolution and coup-d'etat as a means of 'replacing the traditional yoke of servitude with individual freedom.' The positive religious attitude of equality, which Buonarotti argues is prevalent and embodied in both the fundamental precepts of the Terror and the writings of Babeuf, attempted 'to realize through the Revolution a new social order based on equality ... the ideal of social democracy., 271

However, it is problematic to ascertain from where the religious discourse of Babeuf's Voyage des jacobins emerged. In the whole of his earlier writings, Babeuf makes no specific religious reference. It appears that this discourse on religion was confined, like the majority of Babeuf's radical rhetoric, under the association with Guffroy. ${ }^{272}$ Therefore, the only method to evidence the growth of this religious discourse is to research connections between Babeuf and known civil religionists.

In 1789, Babeuf had come to Paris from Roye, Picardy make his mark within the revolution. It was here that became associated with the Cercle Social.

${ }^{271}$ Ibid., 103.

${ }^{272}$ As a child, Babeuf was recognized for his calligraphic skill by the 'abbot of Saint-Quentin.' It appears that much of the early education of Babeuf was received at the hands of this churchman. However, the only direct reference to his education comes from Babeuf's own highly politicized personal history published in $\mathrm{n}^{\circ} 28$ of $\mathrm{Le}$ Tribun du Peuple. 
Started with Claude Fauchet, a priest noted for his powerful sermons, the Cercle Social began as a republican opposition to the municipal leadership of Jean-Sylvain Bailly. ${ }^{273}$ Babeuf's association with Fauchet and the Cercle Social lasted only a few months. However, it appears that this, his earliest political affiliation, contributed dramatically to this revolutionary language.

Arguably, it may have been Fauchet that may have introduced Babeuf to the political power of a civil religion. It was Fauchet who writes of the necessity to 'substitute the religion of the Republic and natural morality for the superstitious and hypocritical cults to which the people is still so unfortunately devoted. ${ }^{274}$ Like Rousseau, and later Robespierre and Babeuf, Fauchet believed that civil society could not exist without a religion: ' $\ldots$. religion is essential in providing a society with social unity and equality; without it the bonds of social constitutions would be without strength, and would be easily torn. ${ }^{275}$ These are ideas that are echoed again and again in the pamphlets and journals of Babeuf. A close reading of the discourse of Fauchet renders a tremendous foundation to the later language of Babeuf.

It is only after the execution of Fauchet and the Gironde that the foundation of a non-Christian based civil religion was laid politically. The rhetoric of civil religion

${ }^{273}$ As the Revolution progressed, the Cercle Social grew as a mouthpiece for a more moderate republicanism. Fauchet was ultimately condemned by Robespierre as an outlawed Girondin in 1793 and was guillotined.

${ }^{274}$ Aulard, Christianity and the French Revolution, 102.

${ }^{275}$ Ibid., 100. 
became adopted by the Revolution as an institution that would purge and purify the established churches of the world. This Revolutionary notion of civil religion rejected the foundations and structures of the Catholic and Protestant religions because after having 1700 years to improve the world, Christianity had succeeded in creating, in Anacharsis Cloot's words, "despotic institutions and absurd doctrines.",276

The calls for civil religion from the Cercle Social would finally find an end in both Babeuf and Robespierre. With Robespierre introduction of the cult of reason and of the Etre Supreme, the potential for a state sponsored religion based on the morality and culture of the nation would step closer to fruition. Under Babeuf, with his creation of Maxmiliennisme, civil religion would move from the praise of an abstract concept to the acknowledgment of a concrete icon.

It was during his tenure with the Cercle Social that Babeuf met Nicolas Bonneville. The significance of Bonneville is his role as a polemical pamphleteer during the last months of the ancien régime. Bonneville began, in the winter of 1789, several months before the storming of the Bastille, a publication called Le Tribun $d u$ Peuple. In this publication, Bonneville voiced his reasoned desire that the Estates General should initiate a complete reorganization of all French political institutions. le (Princeton: University Press, 1985), 105. 
Tribun du Peuple also was one of the first pamphlets, along with Sieyes, to recognize that the Third Estate as the sovereign power of the nation. ${ }^{277}$

Unlike his earlier works, le Tribun du Peuple was written by Bonneville in a clear and plain language intended, apparently, for the consumption at the greatest possible level of French society. ${ }^{278}$ Le Tribun du Peuple was used by Bonneville to further radical and democratic interpretations of popular sovereignty. It was, as well, a voice, that proposed the creation of a civil religion that would replace Catholicism with a native, Gallican, and republican church. Bonneville argued that religion "is literally nothing other than social fraternity." ${ }^{279}$ Bonneville proposed that Christianity be superseded by a religion better suited to the new epoch. A religion that would project the values of the Enlightenment onto a supernatural plane. ${ }^{280}$ Thus, it is interesting that at the moment in which Babeuf discovers Robespierre as a idol of a republican church is the same instant that he renamed le Journal de la Liberté de la presse as le Tribun du Peuple.
${ }^{277}$ Ibid., 20.
${ }^{278}$ Ibid., 21.
${ }^{279}$ Ibid., 102.
${ }^{280}$ Ibid., 113. 
Babeuf and the Return to Jacobinism

Having moved from proponent to opponent of the Thermidorian regime, the political affiliation of Babeuf similarly changed from moderation to radicalization. Having criticized the policies and hypocrisies of the National Convention, Babeuf became alienated from those political affiliations who had guided his rhetoric and message in le Journal de la Liberté de la presse. Removed from the governmental center of the regime, Babeuf moved in the late fall and winter of year III to the periphery.

When Frenc Fehér criticizes Babeuf for his failure in devising an alternative model of revolution, he fails to realize one significant aspect of the Thermidorian political climate. The usurpation of the middle and right by the National Convention forced the voices of dissent to the radical left. Babeuf's immediate re-entry into the mode of Jacobinical dictatorship is, therefore, more a testament to the singularity of Thermidorian opposition than a imaginative deficiency of Gracchus Babeuf.

With his journalistic restoration of Maxmilien the Patriot, Babeuf began a quick re-assimilation into the ranks of the Jacobins. With his publication of le Tribun 
$d u$ Peuple, $\mathrm{n}^{\circ} 18$, on the 18 December 1794 (24 Frimaire), Babeuf's re-conversion to the radical party was completed. This conversion was not, as both Albert Soboul and Georges Lefebvre have argued, a product of Babeuf's tenure in the prisons of Picardy. It was, rather, a reaction the Thermidorian regime. In $\mathrm{n}^{\circ} 18$ of le Tribun $d u$ Peuple, Babeuf declares unabashedly that:

When I was among the first to thunder vehemently in order to bring down the monstrous structure of Robespierre's system, I far from imagined that I was helping to build an edifice which, in a completely different way, would be no less harmful to the people.' . . . The mutual suspicions that had divided the left under Robespierre were suspended. Reactions forged unity in the popular camp. ${ }^{281}$

This tract is an evidence that the conversion was complete before his arrest in February, 1795. In fact, it is the conversion of Babeuf that assured his arrest and imprisonment under the Thermidorians. Nowhere is the conversion to Jacobinism more evident than in the pages of Babeuf's polemical pamphlets.

Though Bazcko dismisses them, there is a tremendous value to the pamphlets printed by Carin's Impermerie de Franklin. They contain the language and first evidence of the radical Babeuf. It is in the pages of Voyage des jacobins, Les battus payant amende and On veut sauver Carrier that Babeuf re-examined his regard for the terrorist of year II. It was in these works that Babeuf began to use the same fury

${ }^{281}$ Denis Woronoff, The Thermidorian regime and the Directory, (Cambridge, New York, and Paris: Cambridge University Press and Editions de la maison des sciences de l'homme, 1987), 7. 
and vitriolic condemnation on the deposers of Robespierre that he had on Robespierre himself.

In both Voyage des jacobins and Les battus payant amende, Babeuf uses his pen to chastise the corruption of the Jacobins in order to facilitate a reunion of republicanism. He writes:

Remember back. ... to before the epoch where your hearts were cannibalized ... you will remember maybe that to return to your first principles, is the preferable action. ${ }^{282}$

Though the pamphlets of Babeuf are severely critical of the Jacobins in the final days, he clearly delineates the possibility of redemption. As the Thermidorian reaction evolved, Babeuf began to see a dichotomy between the Jacobins and the Convention.

Though he chastises the Jacobins that:

Never has the activity of the Jacobin correspondence seemed so great, and the doubled volume of the Journal de la Montagne suffices to continue the intensity of the vows of the affiliated clubs in their pronouncements in favor of the conservation of the regime. These innumerable declarations are a veritable war of polemics against the Convention, and it seems as a prelude and as a manifest of a true war that we are prepared to deliver. ${ }^{283}$

Babeuf also argues in Les battus payant amende that the Convention betrayed the

Republic when they came:

with criminal audacity to put to death our chief and his first lieutenants. We are his officers, disseminated throughout the Republic. It is recognized in us the dispositions to prosper under our advantageous system, since we increased his [Robespierre] favor with the blood of the aristocracy. ${ }^{284}$

${ }^{282}$ Babeuf, Voyage des jacobins, 8.

${ }^{283}$ Babeuf, Les battus payant amende, 16.

${ }^{284}$ Ibid. 
Babeuf continues on to show that the Thermidorians sought to destroy the edifice of the Revolutionary Government only to increase their own personal power and authority.

The maxims you want to substitute for his [Robespierre] offer the precise contrast. The condemnation that you pronounce on dogma announces your intention to condemn also those who were the propagators, and who assured the first successes [of the Thermidorian coup]. Your system, disparate from ours, have struck our revolutionary measures, and has risen with impunity against us ... it dares us [the Jacobins] to reassemble with a menacing indignation. ${ }^{285}$

Far from decrying the Jacobins, Babeuf justifies the conflict between pure virtue of the Jacobins and the tainted corruption of the Thermidorian Convention. This evidenced re-assimilation into the ranks of radical republicanism by Babeuf is further shown in his Voyage des jacobins. Having declared that the Jacobins were justified in their 'veritable war of polemics,' Babeuf holds reaffirms his commitment to democracy and the principles of 1789 when he writes:

We [the People of Paris, the sans-culottes] have not rebelled with you [the Jacobins] at all. But, if you want to believe in us, you will not rebel [against the Thermidorian regime] alone. ${ }^{286}$

However, Babeuf offers his support to the Jacobin cause with a stipulation. Though Babeuf opposes the Thermidorian regime, as the voice of the people he insists that the

\author{
${ }^{285}$ Ibid. \\ ${ }^{286}$ Babeuf, Voyage des jacobins , 18
}


Jacobins 'listen to a religion of peace.' Babeuf says that he represents the liberty of the republic, and that:

Liberty cries to you [the Jacobins] through our voice. Liberty will accept you into her bosom, if, by returning to the grace of nature, you come back to those most philanthropic sentiments [the philosophic origins of Jacobinism], and if you shed the sanguine nature [the Terror]. ${ }^{287}$

\section{Language and the End of the Terror}

The discourse of Babeuf appears in these pamphlets to be a struggle for a justification of the Terror. In his wish to conceive of a virtuous foundation of Jacobinism, Babeuf steadily builds on his structure of a Robespierrist duality. He seeks to distance the patriotic icon from the tyrant. The hypocrisy of the Thermidorian Convention provided the framework and the impetus to solidify the paradoxical notion of Robespierrism and Jacobinism as Conventional opposition.

The tracts of Babeuf evidence his understanding that Robespierre provides the greatest embodiment of the disjointed Revolution. Babeuf presents Robespierre as both a patriot committed to social revolution and as a fanatic deeply possessed of conspiratorial theory.

This dichotomy, however, is not reserved to Babeuf alone. In the nineteenth century, Robespierre was similarly reconstituted by historians. Since the presence and authority of Robespierre could not be removed from the Revolution, the legislator and 
terrorist had to be segregated. Edgar Quinet shows a variation of this separation of

Robespierre when he writes, in Le christianisme et la Révolution française that:

\begin{abstract}
There is something extraordinary and quite unparalleled about these years, that on the one hand, an ideal city of happiness and justice, an age of gold written on the threshold; on the other hand, to put this ideal into practice, an implacable nemesis. One could say that, in order to bring its ideas into the world, the eighteenth century uses the force of the sixteenth century. Two ages coexist, monstrously united: the sentimental logic of Rousseau takes as its instrument the ax of Saint-Bartholomew's Day. .." 288
\end{abstract}

Robespierre appears to Quinet as the link between sentiment and force. Quinet sees Robespierre as the hand that instructed eighteenth-century France in the surgical usage of the ax to remove the cancer of counter-revolution. The resulting argument is that the Terror was both begotten of the perilous conditions of 1793, and endured only as a last resort in the accomplishment of the greater good. ${ }^{289}$

In the twentieth century, the justification of Robespierre has been replaced with a re-examination of the Terror itself. Less interested in the individual of Robespierre, revisionist historians have turned their attention to the continuity of the Terror's discourse. According to François Furet, the Terror was generated by a 'continuing dialectic' between the notion of the general will and the aristocratic plot. Furet asserts that the general will, the vague and highly abstract notion of Rousseau that Robespierre had instituted, required a 'manichean double.' If the general will were not

${ }^{288}$ Mona Ozouf, "War and Terror in French revolutionary Discourse (17921794)," The Rise and Fall of the French Revolution, ed William Blanning, (Chicago: University Press, 1989), 266.

${ }^{289}$ Ozouf, "War and Terror.": 269. 
found to be present, its absence could only be explained by the presence of an aristocratic plot that was dismantling the unity of the public. ${ }^{290}$

In the end, however, the Terror is the final appropriation of the crowd. As an episode of the Revolution, it sought to substitute state violence for a rabid crowd violence. ${ }^{291}$ As an ideal, the Terror was to be 'the fire of liberty which must purify us as the dross is purged from the molten metal in the furnace. ${ }^{292}$ As a revolutionary institution, however, Babeuf conceives of the Terror as nothing more than Robespierre's maxim of 'prompt, severe, inflexible justice.'

It was only when this balance was broken, when the probity of the Terror turned against its authors, that France awoke 'Thermidorian. ${ }^{293}$ It was in this cultural reality that Babeuf initially set pen to paper in 1794. As a journalist he was struggling under the old 'monopoly of information' that had created a 'stranglehold of central power over public opinion.' When Babeuf first began to pen the le Journal de la Liberté de la presse, the only journalistic infrastructure that he had known was that of the Jacobin era. His few polemics from the 1793 had been created under an expression of public sentiment that was categorized by an extravagant rhetoric. Thus, when he

${ }^{290}$ François Furet, Interpreting the French Revolution, trans. Elborg Foster, (Cambridge: University Press, 1986), 301.

${ }^{291}$ Colin Lucas, "The Crowd and Politics between Ancien Régime and Revolution in France." The Rise and Fall of the French Revolution, ed William Blanning, (Chicago: University Press, 1989) : 235.

${ }^{292}$ Christopher Dawson, Gods of the French Revolution, intro Arnold Toynbee, (New York, New York University Press, 1972), 99. ${ }^{293}$ Baczko, Ending the Terror, 36. 
began his enterprise with Guffroy, his discourse was a continuity of both Conventional praise and tyrannical blame. ${ }^{294}$

This continuity of revolutionary language in Babeuf is universal as an abhoration of exclusivity. For Babeuf and the Jacobins, maintaining community was the all important action of the revolutionaries. In this maintenance, it became necessary to eliminate those sections and factions within society that were corruptive or counter progressive to the community. Though Furet argues that it is only with 9 Thermidor that the notion of a society with specific class distinctions is reintroduced, the language of Babeuf shows reaction against distinction is omni-present. The existence, however, of Babeuf's language is not an evidence to a Marxist class conflict. Babeuf's language, rather, shows a transcendence of the traditional notion of estates. ${ }^{295}$ La République indivisible envisioned by Robespierre is defined by Babeuf as a single language of sans-culottisme and political unity.

That Babeuf is found momentarily in the Thermidorian camp is a statement to the particularity of journalism within this regime. At the same time Babeuf is found within the Club Electoral. At this time the politics of Babeuf can be seen as a flux. In September of 1794, Babeuf had moved from the support of the Jacobin regime. At the same moment, Babeuf has yet to understand, as Daline argues, 'le rôle historique de

${ }^{294}$ Ibid., 41.

${ }^{295}$ Adrian Jones, "Towards a New Structiural Theory of Revolution: Universalism and Continuity in the French and Russian Revolutions." European Historical Review, October, (1992) : 868. 
Robespierre .. . le rôle de la dictature révolutionaire. ${ }^{296}$ Daline insists that Babeuf, during the time of his association with de Franklin, did not understand the historic role of the Jacobin dictatorship. Daline argues that it is only after his imprisonment in Picardy, his year long exile under the Thermidorians that Babeuf arrived at an understanding and appreciation of Robespierre. Daline utilizes a tract written in 1796, after Babeuf has spent a year in prison, to evidence his argument that the Thermidorian Babeuf was anti-Robespierrist. Daline argues that Babeuf is reborn a Robespierrist only in February of 1796, when he writes:

\begin{abstract}
Je confesse aujourd'hui de bonne foi que je m'en veux d'avoir autrefois vu en noir, et le gouvernment révolutionaire, et Robespierre, Saint-Just, etc. . . Je crois que ces hommes valaient mieux à eux suels que tous les révolutionaires ensemble, et que leur gouvernment dictatorial était diablement bien imaginé. . Je ne suis pas du tout d'accord avec toi qu'ils ont commis de grands crimes et fait périr bein des républicains. Pas tant. je crois. C'est la réaction thermidorienne qui en a fait périr beaucoup. Je n'entre pas dans l'examen si Hébert et Chaumette étaient innocents. Quand cela serait, je justifie encore Robespierre ... Des brouillons, des hommes à demi-moyens . . . avides de gloire et remplis de présomption, tels qu'un Chaumette, peuvent avoir été apperçus par notre Robespierre avec la volonté de lui disputer la direction du char... Le salut de 25 millions d'hommes ne doit point être balancé contre le ménagement de quelques individus équivoques ... Frippons, ou imbéciles, ou présomptueux et ambitieux de gloire, c'est égal, tant pis pour eux . . . Robespierre savait tout cela, et c'est en partie ce qui me le fait admirer. ${ }^{297}$
\end{abstract}

Babeuf's pamphlets, however, show the inaccuracy of Daline's argument.

Babeuf had achieved an understanding of Robespierre while publishing le Journal de

la Liberté de la presse. This understanding grew into a praise in le Tribun du Peuple

and finally into an admiration in the pamphlets Voyage des jacobins and Les battus

${ }^{296}$ Victor Daline, "Robespierre et Danton vus par Babeuf." Annales

Historiques de la Révolution Française, Vol. 162, (1960) : 402.

${ }^{297}$ Ibid., : 403. 
payant amende. Babeuf is a reconverted Robespierrist by the winter of 1794-95. It would be this re-invention of the 'Incorruptible' that would earn Babeuf imprisonment in Thermidor and ultimate execution under the Directory.

How then does one explain the language of Babeuf immediately after the Fall? It must be seen in a context of political reality. To defend Robespierre after 9

Thermidor would have been suicide, counter-revolutionary, and a crime. ${ }^{298}$ Babeuf's language of early Thermidor was, like most journalists, a discourse that used the same enthusiastic tone and rhetoric of the Terror. The main stylistic difference was verbiage. The Thermidorian journalist merely replaced the words 'faction' and 'federalist' with 'tyrant' and 'Robespierrist.'

In this respect, there was no initial evolution in the revolutionary language. There was, rather, a reversion to an older, pre-Terror linguistic foundation. The metamorphosis had moved from the Gironde, who had 'enthroned eloquence,' to the Mountain and the Jacobin regime that had replaced this elegance with a 'dictatorship of a picked collection of statements' that sought to convey unanimity. ${ }^{299}$ The language of the Terror took its foundation and justification only from the discourse it held about itself. The discourse of the Terrorists and Montagnards merged into a

${ }^{298}$ Baczko, Ending the Terror, 42.

${ }^{299}$ Albert Mathiez, After Robespierre: The Thermidorian Reaction, trans. Catherine Alison Phillips, (New York: Grosset \& Dunlap, the Universal Library, 1965), 20. 
language in which the denunciation of indulgence and the glorification of republican virtue became dominant.

Babeuf and the Critical Public Sphere:

Benjamin Nathans writes that ' $[A]$ s political systems change, so do the forms and functions of public activity. ${ }^{300}$ As the revolution destroyed the institutional arrangements of Ancien Régime France, it also symbolically destroyed the metaphysical assumptions that had defined these symbols. ${ }^{301}$ As the guillotine fell upon Robespierre, a similar destruction took place that redefined the course of the French Revolution. By dismantling the Terror, the Convention legitimized the propertied interest and effectively quieted and destroyed the popular, street based reaction that had given the Mountain its authority.

Thus, the continuity of the discourse of French history within the Revolution can be best seen in Thermidor. The anti-absolutist attitudes that painted Robespierre as a tyrant and as a crypto-royalist is the legacy of the Fronde. This seventeenth-century inheritance grew in the eighteenth century as Jansenism and finally achieved its

${ }^{300}$ Benjamin Nathans, "Habermas's 'Public Sphere' in the Era of the French Revolution." French Historical Studies, Vol. 16, No. 3, (Spring 1990): 621. ${ }^{301}$ Ibid. 
highest rhetorical and popular manifestation in the term 'patriot' in $1794-95 .{ }^{302}$ It is the overlapping of the public functions between the state and commercial class, or bourgeoisie, that creates what Habermas called a 'critical zone.' This zone, in Habermasian theory, provides the necessary conduit that provokes the criticism of a reasoning public. According to Habermas, it is the creation of a formal and published criticism that points to an emerging independence of public judgment which 'challenges the Ancien Régime and its monopoly on interpretation. ${ }^{303}$ Habermas writes:

...the revolutionary process is at once constitutionally interpreted and defined; this may account for the fact that on the continent, the civil public sphere becomes so acutely conscious of its actual or potential political functions. ${ }^{304}$

The method by which this 'revolutionary process' interprets itself is through language.

The growth of language as a cultural and an organic entity is widely supported. It requires, however, an acceptance of the belief that ideology exists as a tangible, yet evolving entity. Though Lynn Hunt argues that the political culture of revolutionary France cannot be deduced from the social structures alone, the revolutionary language of the 1790s appears to have evolved from social conflict and criticism. Through their

${ }^{302}$ Dale Van Kley, "New Wine in Old Wineskins: Continuity and Rupture in the Pamphlet Debate of the French Prerevolution, 1787-1789." French Historical Studies, Vol. 17, no. 2, (Fall 1991) : 40.

${ }^{303}$ Ibid., 622-23.

${ }^{304}$ Jurgen Habermas, The Structural Transformation of the Public Sphere: An Inquiry into a Catagory of Bourgeois Society, trans. Thomas Burger, (Cambridge: Mass., 1989), 90. 
language, revolutionaries worked to reconstitute society and social relations in ideological terms. ${ }^{305}$

Thus, ideology, like language, should be conceived of in structural terms. The ideology of Babeuf, as shown through his linguistic discourse, has been shown as being both shaped by pre-existing ideological realities and harbingers of a new cultural meaning. ${ }^{306}$ The whole of an ideological structure is, according to William H. Sewell, never coherent and totally assembled in a single personality. It is, rather, in a constant state of flux. Language, when studied as a historical agent, provides a tremendous vantage point from which to analyze the re-examination and transformation of ideology. As each actor within the revolution adds, constrains, and enables the social structure under which the ideology exists, a pattern emerges, evolves, and diverges in a linguistic continuity. ${ }^{307}$

It is from this cyclical construction that the Thermidorian discourse of denunciation was utilized by Babeuf to devise a new criticism of the Revolution. It was by removing Robespierre the Tyrant that the Thermidorians unwittingly gave rise to Maxmilien the Patriot. Babeuf's reconstitution of Robespierre in both Voyage des jacobins and Les battus payant amende evidences the emergence of a new critical

${ }^{305}$ Lynn Hunt, Politics, Culture, and Class in the French Revolution, (Berkeley: Los Angeles:University of California Press, 1984), 12.

${ }^{306}$ William H Sewell, Jr, "Ideologies and Social Revolution: Reflextions on the French Case." The Rise and Fall of the French Revolution, ed. William Blanning, (Chicago: University Press, 1989), 288

${ }^{307}$ Ibid., 288-89. 
public sphere. Babeuf arose as the voice of a specific section of the French public in 1794. However, the unifying theme of this Babouvist collective mentality was not a class, in the Marxian sense, but rather an ideology and a new system of language that seized power. François Furet refers to this republican unity during the Thermidorian reaction as an 'ideological dynamic.' ${ }^{308}$ For Furet, class, warfare, and political factionalism within Thermidor were not constraints. They were specific and necessary movements for the shaping ideological developments. ${ }^{309}$

Furet argues that it was not until the Thermidorian reaction that civil society reemerged with it 'unweildiness,' its inherent conflict of interests, and its internal divisions. Babeuf as both a journalist and critic of the Thermidorian regime is a tremendous example of this evolution. The discourse and rhetoric employed by Babeuf speaks directly to the inherent contradictions and hypocrisy of the post-Terror Revolution. Babeuf evidences this attack in his $\mathrm{n}^{\circ} 28$ of le Tribun du Peuple when he writes:

All the vices and rottenness of the ancien régime are boldly showing themselves again and blot out the men and principles of the republic. On all sides nothing is to be met with but degradation, depravation of morals, prostitution, and corruption. ${ }^{310}$

Babeuf is addressing himself to the degeneration of republican morality in PostThermidor Paris. Babeuf and the remnants of the republic of Virtue were shaken by

${ }^{308}$ Sewell, "Ideologies and Social Revolution.": 301.

${ }^{309}$ Ibid., 302.

${ }^{310}$ F-N. 'Gracchus' Babeuf, Tribun du Peuple, n 28, (Paris: Franklin, rue de Clery 75, 1795), 235. 
the rapid and total decay of society after 9 Thermidor. François Gendron argues a Paris that was stricken by an 'explosion of indulgence.' With the end of Terror came 'roars of laughter, a riotous race for pleasure, and a lust for life. ${ }^{311}$ The remnants of the radical party and its press were not unaware of this Thermidorian excess. Lebois writes in his l'Ami du Peuple that:

The superficial man sees nothing more in this bizarre metamorphosis that the capricious tastes of fashion (meaning the blond wigs and black collars of the Jeunesse dorée). The philosopher, in contrast, attributes it to a variety of moral, political, and revolutionary causes. ${ }^{312}$

The Journal des hommes libres of Vatar undertook a more caustic analysis of the social and political climate of Paris. In the face of this degradation of civic and revolutionary virtue, the radical journal states:

Look at what is happening around us. Look at all the schemers and crooks gathering and joining forces. Look at all the suspect men, known aristocrats, and even disguised aristocrats, joining together to form one large pack that rails against the revolutionary institutions. $^{313}$

The Jacobin Audouin, who had been attacked by Babeuf in Les battus payant amende, writes in his Journal universel that the 'aristocracy' was stirring up trouble against the patriots. Audouin sounded the alarm to the sans-culottes that public spirit was

${ }^{311}$ François Gendron, La Jeunesse dorée sous Thermidor, (Paris: Les Presses Universitaires de France, 1983), 31.

${ }^{312}$ Ibid., 11.

${ }^{313}$ Ibid., 10. 
'deteriorating' in the sections and that a reaction against republicans was looming. ${ }^{314}$

Audouin continues to write that:

... without anyone's realizing it, the vigorous style of the republic is giving way to the syrupy style of the monarchy. ${ }^{315}$

The radical reaction was caused by the deputies of the National Convention.

Tallien began, soon after the fall, to advocate the reintroduction of those elements of society that had been eliminated under the Terror: the Gironde and the émigrés.

Tallien justified his belief by saying:

Are we to believe that the Republic, with its 1.2 million armed citizens, ought to fear a handful of aristocrats? ${ }^{316}$

Tallien continued to give discomfort to the remnants of the Jacobins when, on 2

Fructidor, year III, he proposed that the distinction between aristocrats and patriots be eliminated:

What does it matter to me that a man is born a noble, provided he conducts himself properly? What do I care that a man is a plebeian if he is a crook? ${ }^{317}$

Babeuf's rendering of the horrific fluctuation of the republican fortunes under the Thermidorians illustrates what Habermas called the 'precarious status of the civil public sphere.' 318 Babeuf's pamphlets are evidences of the political fortunes of post-

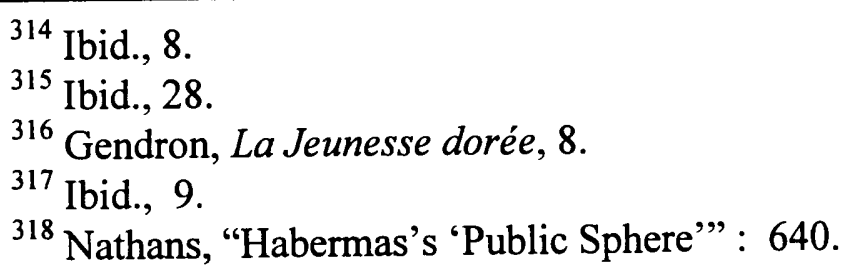


Robespierrist France. The pamphlets and polemic penned by Babeuf are an evidence to what Keith Michael Baker refers to as 'the process by which competing claims and policies are transformed into authoritative definitions of the general good. 319 The rise of a republican public sphere can be seen in the discourse of the radical journalists. With their criticisms and condemnation of the degradation of revolutionary progression, men like Lebois and Babeuf are giving voice to a political ideology that exists beyond the unanimous confines of the governmental center.

Within his pamphlets and news-sheets, the battle for political dominance in Thermidorian France takes a tangible form in both the print and the language of Babeuf. This connection between politics and language, Lynn Hunt argues, is nearly unalienable. Hunt argues that the struggles unify under the desire for the right to speak on behalf of the nation. ${ }^{320}$ Babeuf's language became an expression of power that was expressed by his assumption to speak for the people.

Babeuf and his Execution under the Directory

The discourse of both Babeuf's Tribun du Peuple and polemical pamphlets in the moments before his arrest was one that conceived of the Revolution as a protracted

${ }^{319}$ Keith M Baker, "Politics and Public Opinion Under the Old Regime: Some Reflections." Press and Poltics in Pre-Revolutionary France, ed. J. Popkin and J. Censor, (Los Angeles and Berkeley: Universioty of California Press, 1987): 209. ${ }^{320}$ Hunt, Politics, Culture, and Class in the French Revolution, 23. 
civil war between the two ideologies. The division lay between the plebeians, whose cause relied on justice, philanthropy and selflessness, and the patricians, whose resources were cunning, duplicity, perfidy, pride and ambition. ${ }^{321}$ The Revolution, Babeuf declared, had been a progression towards new stages of achieving a Rousseauist notion of social equality up to 9 Thermidor. The Thermidorian regimes that had replaced Robespierre, Babeuf argued, had resulted in a tremendous regression toward the patrician ideals of the old regime. ${ }^{322}$

As the Thermidorian reaction ground to a halt in 1795 , public opinion was engrossed in exorcising sans-culottism, depantheonizing Marat, and the institution of a new bourgeois constitution. ${ }^{323}$ In the shadows of this political evolution, the newly released Gracchus Babeuf set pen to paper and began to republish his le Tribun $d u$ Peuple. His arrest by the Thermidorian regime had elevated his stature and power as a radical voice. Freed from the constraints of prison in late fall 1795, Babeuf declared himself the Achilles ${ }^{324}$ of the new plebeian army that had declared war on the Directory. The war was to be waged against the bourgeois republic that had replaced Robespierre's Terror. ${ }^{325}$

${ }^{321}$ Rose, R.B., Gracchus Babeuf, 212.

${ }^{322}$ Ibid, 211.

${ }^{323}$ Isser Woloch, Jacobin Legacy: The Democratic Movement Under the Directory, (Princeton, Princton University Press, 1970) 14.

${ }^{324}$ Yet another examples of Babeuf's relentless use of classical imagery.

${ }^{325}$ Rose, Gracchus Babeuf, 210. 
Babeuf evidences the rise of a new form of Jacobinical egalitarianism. With the clubs both closed and denied active roles within the political process, Babeuf and the radical press became the medium for old guard Jacobin and Hébertist unity. The betrayal of Babeuf by his publisher in 1795 had a significant effect on the production and distribution of his radical journalism. As his political rhetoric became more inflamed, his authority as a critic increased.

It was this rhetoric against the failings of the Thermidorian regime that cost Babeuf his freedom. The Babeuf of Thermidor embodied the new post-Terror Jacobinism: he idealized Robespierre as a martyr and the sans-culotte as citizen. ${ }^{326}$ It was, however, the internal weakness of the Thermidorian Convention that secured Babeuf's freedom in 1795 . The reaction of 9 Thermidor ultimately gave way to the new executive regime of the Directory. Babeuf was released from Les Baudets prison and freed, hypothetically, to resume his journalism.

Despite the general amnesty that freed many of the radicals imprisoned during 1794, the change in governments from the Thermidorian Convention to the Directory did not result in any radical or democratic change in French society. France, Babeuf acknowledged, was no closer to freedom under the Directory than it had been under the king. The Directory neither secured the political liberty nor assured the societal

${ }^{326}$ Woloch, Jacobin Legacy, 15. 
evolution that Babeuf advocated in his Tribun du Peuple and polemical pamphlets.

Babeuf comments on this reality in issue thirty-four:

le Tribun du Peuple is free ... what have I said, that I am free? I am not. I remain enchained. I have only changed prison. I have left one incarceration, only to condemn myself voluntarily to another. ${ }^{327}$

The new regime promised no great advancement for the assurance of 'Libérte, égalité et fratérnité.' Albert Vandal writes in 1912 that the Directory 'could neither restore nor establish anything. It gave to the French neither order nor liberty. . , 328 According to Vandal, the Directory had, while discrediting its predecessors, nonetheless inherited all of the faults of the Terror: war, famine, and the threat of civil unrest.

By 1795 the world of politics, Isser Woloch writes, 'was divided between the Directory's entrenched conservatism and Babeuf's insurrectionary radicalism. ${ }^{329}$ The Non-Babouvist journalistic discourse was preoccupied with an anti-republican subversion. They assumed a role of loyal opposition. Their articles asked that the Directory recognize between the true friends of la patrie and demanded the expulsion of the most incendiary and reactionary elements of the old royalist right, the émigrés, priests and white terrorists. ${ }^{330}$ Unlike these appeasing opponents of the Directory,

${ }^{327}$ F.-N. 'Gracchus' Babeuf, Le Tribun du Peuple: Le Défenseur des Driots de l'Homme, No, 34, (Paris, 5 Ventôse, IV).

${ }^{328}$ Albert Vandal, L'Avèncement de Bonaparte, 17th edition, (Paris, Plon, Nourrit, 1912) 1, as cited by Woloch.

${ }^{329}$ Woloch, Jacobin Legacy. 20.

${ }^{330}$ Ibid., 24. 
Babeuf believed that the bourgeois republic that followed the downfall of Robespierre was unredeemable. ${ }^{331}$

Though the mainstream Jacobin press initially supported the re-emergence of Babeuf's le Tribun du Peuple in 1795, the violence of his rhetoric and continued support of the Robespierrist regime alienated Babeuf from all but the most radical of republican journalists. With the resumption of publication of le Tribun $d u$ Peuple, Vatar, the publisher of le Journal des hommes libres, disavowed the 'imprudent pages which at this time can only fan the flames of discord.' The Orateur plébien also published its editor's fear that Babeuf intended to bring about another disastrous insurrection in which 'the gullible sans-culottes would be cut down as the royalists gleefully looked on.' 332

Babeuf published his new journal on 6 November 1795. The new Tribun $d u$ Peuple was greeted by a curiously concerted storm of abuse in the remainder of the press. However, the condemnations were not unanimous. Felix Lepelletier writes several opinion pieces in Vatar's le Journal des hommes libres, as apologies for the violence of Babeuf's rhetoric. Lepelletier declared that Babeuf had to be protected because of the strength of his enemies. Harassed and proscribed by the makers of the bourgeois republic, Babeuf became an object of Jacobin solicitude. ${ }^{333}$

${ }^{331}$ Ibid., 27.

${ }^{332}$ Ibid., 40.

${ }^{333}$ Ibid., 41. 
The Directory, like the Thermidorians before them, unintentionally fueled the popularity and mystique of Babeuf. The whole of the second series, $n^{\circ} 34$ of le Tribun $d u$ Peuple ou les defenseurs des droits de l'homme, was confiscated by the police on 30 November 1795 . $^{334}$ The Directory realized that the incendiary language of Babeuf was swaying the popular sentiments towards the old Robespierrist regime. The consistency of official police reports regarding Babeuf's le Tribun du Peuple, from issue $\mathrm{n}^{\circ} 28$ during the Thermidorian reaction to the Directory's condemnation of $\mathrm{n}^{\circ}$ 35, evidence that the regimes were not as much interested in Babeuf's notions of 'communism' as his open support of Robespierre. ${ }^{335}$ The Directory and the Thermidorians responded to the threat of Babeuf in a similar, and equally ineffective fashion. As both governments attempted to suppress the opinions and writings of Babeuf they succeeded only in elevating his image among Jacobinical remnants. ${ }^{336}$ The more the Directory and Thermidorians attempted to paint Babeuf as a dangerous fanatic, the more his rhetoric was deemed acceptable by the radicals of the republican and democratic party. As their condemnation of Babeuf grew stronger, the authority with which Babeuf writes increased. The result of this policy was to create a powerful peripheral critic to the governmental center. Ultimately, the power and the danger of Babeuf lay in that fact that his journal was the one that the énrages, Hébertists and

${ }^{334}$ Rose, Gracchus Babeuf, 209.

${ }^{335}$ Ibid., 234.

${ }^{336}$ Woloch, Jacobin Legacy, 41. 
Jacobins could welcome with equal enthusiasm. Its rhetoric on equality and exploitation squarely confronted the opportunists of the Directorial party. ${ }^{337}$

Under both the Thermidorians and the Directory, Babeuf centered his journal on the examination of political inequality. Unlike his earlier works from the Thermidorian reaction, however, inequality was no longer solely an historical and economic process. Babeuf's égalité reéle became an economic as well as a political concept. It was defined against the entire record of human history. The human condition of material inequality and exploitation appeared to be no more tolerable in a modern republic than under the timeless exploitation of the past. Exploitation was the problem, and private property was the cause. ${ }^{338}$ Property rights- whether social or natural in origins- were considered by the Jacobins subject to regulation as long as 'hunger was the order of the day.' Criticizing the Directory, Babeuf conceived that the patricians had slowly removed and consolidated property and rights from the people. In le Tribun du Peuple, Babeuf was determined to prove that continuance of inequality after the Revolution had resulted from the deliberate rejection of the fundamental moral principles of equality that Robespierre had advocated in year II. ${ }^{339}$

At Babeuf's trial in May of 1797, a jury was unable to find sufficient evidence to prove that the conspiracy for equality existed anywhere but in the anxious and

${ }^{337}$ Rose, Gracchus Babeuf, 218.

${ }^{338}$ Woloch, Jacobin Legacy, 33.

${ }^{339}$ Rose, Gracchus Babeuf, 213. 
paranoid minds of the governmental witnesses and officials. What was evident and capital in the Directory's case against Babeuf was his avocation of the Robespierrist regime. Babeuf was found guilty on 26 May 1797 of promoting the Constitution of 1793 and supporting the regime of Maxmilien Robespierre and the Jacobins. On 27 May, 1797Babeuf was led silently to the guillotine and executed for crimes committed against the republic in the production, distribution, and conception of le Tribun $d u$ Peuple. 


\section{APPENDIX I}

Thermidorian Timeline of Babeuf, his Publications, and the Thermidorian reaction.

REPUBLICAN

AN II

09 Thermidor, II

10 Thermidor, II

17 Fructidor, II

$03 \mathrm{Sep}, 94$

21 Fructidor, II

07 Sep, 94

29 Fructidor, II

15 Sep, 94

01 san-culottide, II

17 Sep, 94

(La Fête de Vertu)

03 san-culottide, II $19 \mathrm{Sep}, 94$ who

Messidor.

05 san-culottide, II $21 \mathrm{Sep}, 94$

AN III

06 Vendemaire, III 28 Sep, 94

18:

10 Vendemaire, III 03 Oct, 94

21:

14 Vendemaire, III 07 Oct, 94 de

17 Vendemaire, III 08 Oct, 94

20 Vendemaire, III 11 Oct, 94

21 Vendemaire, III 14 Oct, 94

22 Vendemaire, III 15 Oct, 94

17 Brumaire, III

19 Brumaire, III

22 Brumaire, III
07 Nov, 94

09 Nov, 94

12 Nov, 94
EVENT

Fall of Robespierre

Execution of Robespierre, Saint-Just, and Couthon

Journal de la Liberté de la presse $\mathrm{n}^{\circ} 1$ : Guffroy

Attempted assination of Tallien.

Lebois/Chasles launch L'Ami du Peuple.

Journal de la Liberté de la presse $\mathrm{n}^{\circ} 10$ :

Guffroy

Convention expells from Paris all those had not resided there before 1

Marat placed in Pantheon.

le Journal de la Liberté de la presse $\mathrm{n}^{\circ}$ Guffory

le Journal de la Liberté de la presse $\mathrm{n}^{\circ}$ Last Journal pubished by Guffroy

le Tribun du Peuple $\mathrm{n}^{\circ}$ 23: 1st of Droits l'Homme

Leblois draws indictment against Carrier.

Rousseau placed in Pantheon

Guffroy breaks relation with Babeuf.

le Tribun du Peuple ${ }^{\circ}$ 27: Babeuf

denounces Guffroy

On veut sauver Carrier. Franklin

Junesse dorée attack Jacobin Club.

Closure of Jacobin Clubs 
24 Brumaire, III

30 Brumaire, III

15 Frimaire, III

18 Frimaire, III

26 Frimaire, III

28 Frmaire, III

04 Nivôse, III

07 Nivôse, III
14 Nov, 94

18 Oct, 94

05 Oct, 94

$08 \mathrm{Dec}, 94$

$16 \mathrm{Dec}, 94$

$18 \mathrm{Dec}, 94$

24 Dec, 94

27 Dec, 94
Carrier sent before revolutionary

Tribunal.

Les Battus payant l'amende, Franklin

Voyages des Jacobins, Franklin.

Return of Girond deputies to Convention

Carrier sentenced to death

le Tribun du Peuple $\mathrm{n}^{\circ}$ 28: Franklin

Abolition of Maximum

Commission set-up to investigate Collot

d' Herbois, Billaud-Varenne, Vadier and Barère.
1795

13 Nivôse, III

14 Nivôse, III

19 Nivôse, III

20 Nivôse, III

09 Jan, 95

21 Nivôse, III

19 Jan, 95

04 Pluvois, III

29 Jan, 95

10 Pluvois, III

$02 \mathrm{Feb}, 95$

14 Pluvois, III

15 Pluvois, III

20 Pluvois, III

06 Feb, 95

$07 \mathrm{Feb}, 95$

$08 \mathrm{Feb}, 95$

12 Ventôse, III

02 Mar, 95

21 Germinal, III

$10 \mathrm{Apr}, 95$

17 Prairial, III

20 Prairial, III

05 Jun, 95

08 Jun, 95

06 Messidor, III

29 Jun, 95

15 Brumaire, IV

07 Nov, 95
Arrest of Carin and Marie-Ann Babeuf. Du Systéme de depopulation: Franklin le Tribun du Peuple $\mathrm{n}^{\circ}$ 29: republisehd later as :G. Babeuf, Tribun du Peuple à ses Concitoyens. published by Franklin. Gravilliers Section petitions Convention for introduction of 93 Constitution. Arrest of Petit and Camelin from Gravilliers.

le Tribun du Peuple $\mathrm{n}^{\circ}$ 31:

Denunciation of Fréron

Boursault report on affect of Babeuf on the bread riots of Rennes

le Tribun du Peuple $\mathrm{n}^{\circ} 32$

Arrest of Babeuf

Marat removed from Pantheon.

Arrest and indictment of Barère, Herbois. Law disarming Terrorists/confinement Massacre of Jacobins in Lyon Announcement of Louis XVII's death Verona Manifesto by Louis XVIII le Tribun du Peuple $\mathrm{n}^{\circ} 34$ 


\section{APPENDIX II}

The Publications of F.-N. 'Gracchus' Babeuf:

1789-1796

Babeuf, F.-N. Le Cadastre Perpétuel. (Paris, chez Garnery \& Volland, quai des Augustins, no 25, chez les Auteurs, rue Quincampoix, no. 40. Versailles, chez Blaizot. 1789).

Babeuf, F.-N. La Nouvelle Distinction des Ordres. (Paris, chez Volland, quai des Augustins, 1789).

Babeuf, F.-N. C. Fournier (Américain) à Marat. (Paris, de Mayer et Compangie, rue St.Martin, no. 219, 14 Mars II).

Babeuf, F.-N. 'Gracchus'. Paris sauvé par l'administration des subsistances. (Paris, de · Patriotique et Républicaine rue St. Honoré, n 355, II).

Babeuf, F.-N. 'Gracchus' Les Battus Payant amende, ou les jacobins jeannots. (Paris, de Franklin, rue de Cléry, no. 75).

Babeuf, F.-N. Journal des Hommes Libres de Tous les Pays, ou Le Républicain.

(Paris, de Journal des Hommes Libres rue de l'Université, no. 139. 12 Ventôse IV).

Babeuf, F.-N. Nouveau Calandrier de laRépublique Française. (Paris: chez l'Autour, rue Porte Honoré, 219, 1792).

Babeuf, F-.N. 'Gracchus' Du systême de d'epopulation, ou la vie et les crimes de Carrier. (Paris, de Franklin, rue de Cléry, no. 75, 1794)

Babeuf, F.-N. 'Gracchus' Voyage des Jacobins dans les quatre parties du monde (Paris, de Franklin, rue de Cléry, no. 75, 1794).

Babeuf, F-.N. 'Gracchus' On veut sauver Carrier. (Paris, de Franklin, rue de Cléry, no. 75,1794$)$

Babeuf, F.-N. 'Gracchus' G. Babeuf/Le Tribun du Peuple à ses concitoyens. (Paris, de Franklin, rue de Cléry, no. 75, 1794). 
Babeuf, F.-N. 'Gracchus' Address du Tribun du Peuple à l'armée de l'interior. (Paris: Tribun du Peuple, 1795).

Babeuf, F.-N. Journal de la Confédération. (Paris: Laillet et Garnery, 1790).

Babeuf, F.-N. Le Correspondant Picard. (Noyon: Devin, 1790-91).

Babeuf, F.-N. le Journal de la Liberté de la presse :

17 Fructidor, II

(Capucins)

19 Fructidor, II

(Capucins)

22 Fructidor, II

(Capucins)

25 Fructidor, II

(Capucins)

25 Fructidor, II

(Capucins)

27 Fructidor, II

(Capucins)

28 Fructidor, II

(Capucins)

29 Fructidor, II

(Capucins)

29 Fructidor, II

(Capucins)

(Capucins)

3 san-culotide, II

(Capucins)

(de la fete du Travail)

4 san-culotide, II No. 12

(Capucins)

(de la fete de l'Opinion)

1 Vendémaire, III No. 13

(Capucins)

2 Vendémaire, III No. 14

(Capucins)

3 Vendémaire, III No. 15

(Capucins) de Guffroy

de Guffroi

de Guffroy

de Guffroy

de Guffroy

de Guffroy

de Guffroy

de Guffroy

de Guffroy

de Guffroy

de Guffroy

de Guffroy

de Guffroy

de Guffroy

de Guffroy rue Honoré, no 35

rue Honoré, no 35

rue Honoré, no 35

rue Honoré, no 35

rue Honoré, no 35

rue Honoré, no 35

rue Honoré, no 35

rue Honoré, no 35

rue Honoré, no 35

rue Honoré, no 35

rue Honoré, no 35

rue Honoré, no 35

rue Honoré, no 35

rue Honoré, no 35

rue Honoré, no 35 


$\begin{array}{lccc}\begin{array}{l}4 \text { Vendémaire, III } \\ \text { (Capucins) }\end{array} & \text { No. } 16 & \text { de Guffroy } & \text { rue Honoré, no } 35 \\ \begin{array}{l}\text { 5 Vendémaire, III } \\ \text { (Capucins) }\end{array} & \text { No. } 17 & \text { de Guffroy } & \text { rue Honoré, no } 35 \\ \begin{array}{l}\text { 6 Vendémaire, III } \\ \text { (Capucins) }\end{array} & \text { No. } 18 & \text { de Guffroy } & \text { rue Honoré, no } 35 \\ \begin{array}{l}\text { 8 Vendémaire, III } \\ \text { (Capucins) }\end{array} & \text { No. } 19 & \text { de Guffroy } & \text { rue Honoré, no } 35 \\ \begin{array}{l}\text { 9 Vendémaire, III } \\ \text { (Capucins) }\end{array} & \text { No. } 20 & \text { de Guffroy } & \text { rue Honoré, no } 35 \\ \begin{array}{l}10 \text { Vendémaire, III } \\ \text { (Capucins) }\end{array} & \text { No. } 21 & \text { de Guffroy } & \text { rue Honoré, no } 35 \\ 10 \text { Vendémaire, III } & \text { No. } 22 & & \end{array}$

Babeuf, F.-N. 'Gracchus' Le Tribun du peuple: ou Le Défenseur des Driots de l'Homme

\begin{tabular}{|c|c|c|}
\hline 14 Vendémaire, III & No. 23 & \\
\hline 16 Vendémaire, III & No. 24 & \\
\hline 17 Vendémaire, III & No. 25 & \\
\hline 19 Vendémaire, III & No. 26 & \\
\hline 22 Vendémaire, III & No. 27 & \\
\hline 28 Vendémaire, III & No. 28 & rue de Cléry, no. 75 \\
\hline 19 Nivôse, III & No. 29 & rue de Cléry, no. 75 \\
\hline 4 Pluviôse, III & No. 30 & du Tribun du Peuple \\
\hline 9 Pluviôse, III & No. 31 & du Tribun du Peuple \\
\hline 13 Pluviôse, III & No. 32 & du Tribun du Peuple \\
\hline & No. 33 & $\begin{array}{l}\text { chez le citoyen ROCHE rue du Faubourg- } \\
\text { Honoré,no } 29\end{array}$ \\
\hline 15 Brumaire, IV & No. 34 & \\
\hline 9 Frumaire, IV & No. 35 & $\begin{array}{l}\text { chez le citoyen ROCHE rue du Faubourg- } \\
\text { Honoré, no } 29\end{array}$ \\
\hline 20 Frimaire, IV & No. 36 & $\begin{array}{l}\text { chez le citoyen ROCHE rue du Faubourg- } \\
\text { Honoré, no } 29\end{array}$ \\
\hline 30 Frimaire, IV & No. 37 & $\begin{array}{l}\text { chez la citoyen LANGLET, rue du Faubourg- } \\
\text { Honoré, no } 29\end{array}$ \\
\hline 1 Nivôse, IV & No. 38 & \\
\hline 10 Pluviôse, IV & No. 39 & $\begin{array}{l}\text { chez la citoyen LANGLET, rue du Faubourg- } \\
\text { Honoré, no } 29\end{array}$ \\
\hline 30 Pluviôse, IV & & $\begin{array}{l}\text { de L'ami du peuple [R.F. Lebois] } \\
\text { rue ci-devant Sorbonne, no. } 382 .\end{array}$ \\
\hline
\end{tabular}


5 Ventôse, IV

10 Germinal, IV

5 Floréal, IV
No. 40

No. 41 chez la citoyen LANGLET, rue du FaubourgHonoré, no 29

No. 42 chez la citoyen LANGLET, rue du FaubourgHonoré, no 29 


\section{APPENDIX III}

\section{Babeuf and Critical Theory}

The Study of Revolutionary Language:

The Structure and Deconstruction of Babeuf:

Linguistic Theories of Revolutionary Journalism.

Historical linguistic criticism has evolved from the Marquise de Condorcet's abstract theory of universal language ${ }^{340}$ to Jacques Derrida's rejection of subject based linguistics. ${ }^{341}$ Le Peuple sans-culotte de Paris à la Legion de Police, a polemical pamphlet written by Gracchus Babeuf during the months after the fall of Robespierre, provides a fascinating vantage point from which to examine the advancement from modern to post-modern criticism. Through an exploration of this evolution, it is possible to elucidate the structure of Babeuf's revolutionary language. This pamphlet serves as an excellent illustration of the structuralist argument of linguistic usage. Le Peuple sans-culotte de Paris à la Legion de Police can be examined to show the axiomatic debate between Condorcet and Ferdinand de Saussure over the utility of

${ }^{340}$ This notion, ironically, promoted by one of the great Girondists, would be adopted by Robespierre and the Jacobins as a medium to spread Enlightement and Revolution throughout France.

${ }^{341}$ Joyce Appleby et al. Knowledge and Postmodernism in Historical Perspective, Elizabeth Covington, David Hoyt, Michael Latham and Allison Sneider, (New York, London, Routledge, 1996), 386. 
revolutionary language as a cultural tool. The pamphlet allows for the utilization of the divergent and exclusive 'structuralist' theories of Claude Lévi-Strauss and Jacques Derrida to examine the interplay of complementary and contradictory linguistics vehicles. It is from this analysis of the text that the importance of Babeuf's linguistic usage can be established as an historical determinant.

To examine in any detail the significance of Le Peuple sans-culotte de Paris $\grave{a}$ la Legion de Police requires an introduction to the method of linguistic analysis from Condorcet to de Saussure. It was during the loosely defined modern era (assuming the argument that the modern began with Descartes and the rise of the scientific method) that the typology of writing was moved away from the mystical realm of theology to the more secular venue of contracts. Language, therefore, evolved from the conveyance of philosophy to the scientific verification of facts. ${ }^{342}$ The certitude and irrefutability of the truth, conceived according to the models of logical deduction and mathematical reasoning of the Enlightenment were fundamentally differentiated from the ill-founded convictions imposed and reinforced by the earlier art of rhetorical persuasion. ${ }^{343}$ The metamorphosis of language resulted in a significant redefinition of subject. It was the Enlightenment that had replaced God with man. It was, however, the French Revolution that replaced homme with citoyen.

${ }^{342}$ Roger Chartier. Forms and Meaning: texts, Performances, and Audiences from Codex to Computer. (Philadelphia, Univeristy of Pennsylvania Press, 1995), 8. ${ }^{343}$ Ibid., 9. 
The evolution of man to citizen is shown in Babeuf's Le Peuple sans-culotte de Paris à la Legion de Police. For the language of the sans-culottes, and therefore the structure of this polemic, the power of liberation did not rest in a supreme God, but in the people. Babeuf writes:

Has the moment come to break the new scepters? Is liberty fixed in the days when we are under the common oppression? ${ }^{344}$

This specific use of language evidences the structural emergence of Condorcet's ideal of both universal opinion and political language as a linguistic concept. Condorcet argued, in 1776, that ideas were social rather than individual in origin. Therefore, not only could they not be considered a form of private property, ${ }^{345}$ they were popular and public.

For Condorcet, then, the creation of 'public opinion' is the result of the printing revolution. ${ }^{346}$ Public opinion is formed, 'powerful by the number of those who share it, energetic, because the motives that determine it act upon all minds at once.' For Condorcet, the result of this collective activity is that a tribunal is erected. Condorcet writes that the power of this tribune is that it exists:

${ }^{344}$ F.-N. 'Gracchus'Babeuf, Les Peuple sans-culotte de Paris à la legion de Police. (Paris, 1795), 1.

${ }^{345}$ Carla Hesse, Publishing and Cultural Poltics in Revolutionary Paris, 17891810. (Berkeley, Los Angeles, and Oxford: University of California Press, 1991), 106. ${ }^{346}$ Babeuf, Les Peuple sans-culotte, 9. 
in favor of reason and justice, independent of all human power, from the penetration of which it is difficult to conceal anything, from whose verdict there is no escape. ${ }^{347}$

For this public opinion to exist, there must exist first a universal and public instruction that would break the 'Church's control over education and would give to everyone that necessary competence to read.' Secondly, public opinion requires the establishment of a common language. ${ }^{348}$ From this from this creation, Condorcet argues that:

a new species of tribune is established, from which are communicated impressions less lively but at the same time more solid and profound; from which is exercised over the passions an empire less tyrannical, but over reason a power more certain and durable; where all the advantage is more than counterbalanced by the illumination [the Enlightenment] it conveys. ${ }^{349}$

This vision of a universal language would come to fruition under the matrix of Jacobin linguistic republicanism. It is from this base that Gracchus Babeuf would construct, in the Fall of 1794, a tribun to spread and promulgate a revolutionary language of equality and criticism, Le Tribun du Peuple. Babeuf would seek to define a structural rhetoric through the construction and use of a common and universal language of sansculottisme. The revolutionary language of Babeuf would be built from the remains of Robespierrest rhetoric, and infused with a sharp criticism of the hypocrisy of Thermidorian discourse.

${ }^{347}$ Condorcet, Marquis de, Esquisse, 121.

${ }^{348}$ Chartier, Roger, Forms and Meaning, 10.

${ }^{349}$ Condorcet, Esquisse, 145 
Les Peuple sans-culotte is an example of the tribune of advocated by Condorcet. It is a manifestation of the concrete subjectivity of public opinion. Babeuf in 1795 , in the shadow of the Jacobin dictatorship and the hypocritical politics of the Thermidorians, pens a pamphlet in a universal language. This Babouvist language of revolution posits itself as a conduit between the creation of the Enlightenment man and the fabrication of the Revolutionary citizen as a universal subject. The junction of these two theorems lies the exaltation of the citizen as:

... finally able to take the initiative as the liberators of the people. . . Your friends, your brothers, your spouses, your parents claim that in you they will not see a return to the murdering that was once your destiny, you will not abandon them to another slaughter within these walls. ${ }^{350}$

Unlike Condorcet, Ferdinand de Saussure attacked the notion of language as a representation of a fixed and individual reality. Individual subjects did not speak languages. De Saussure argued that there is no molding of private marks to meet the specific purposes of the individual. Words spoken are rendered meaningful only through shared usage by groups. ${ }^{351}$ Language is therefore both a social product and "a collectivization of necessary convention adopted by a body social to permit individuals within society to communicate." ${ }^{352}$ It is, for Saussure, a total system

${ }^{350}$ Babeuf, Les Peuple sans-culotte, 4.

351 Appleby, Knowledge and Postmodernism, 388.

352 John Sturrock, Structuralism and Since, (Oxford, Oxford University Press, 1979) 21 . 
which is complete at every moment. The language of Saussure, therefore, is the theoretical system or structure in which language is valid apart from history. Language exists as the 'corpus of linguistic rules' which constitute communication regardless of the cultural and political realities presents at its initial usage. ${ }^{353}$

In looking at the language Le Peuple sans-culotte de Paris à la Legion de Police, however, it is difficult not to be aware that Babeuf rhetoric was a structural representation of the cultural realities of the 1790s. Babeuf's language, arguably, reflects both the era and the politics in which it was written. Babeuf seeks to capture a universal language through his use of metaphor and reference. His terms are simple, yet they convey a strength through being known and understood. He writes:

You have manifested that you do not want to join the party of executioners. . Paris is blocked, Paris is menaced by blood and fire, because it [Paris] is forced to be, with all the Republic, famished, naked, and disgraced; Paris finally under the yoke of the barbaric usurpers. ${ }^{354}$

The linguistic representation is obvious. Babeuf is not attempting to examine the particularities of any political doctrine. He is, rather, speaking an impassioned and metaphoric language that creates a specific, recognizable, and fearful image in the minds of the reader.

353 Ibid., 9.

${ }^{354}$ Babeuf, Les Peuple sans-culotte, 2. 
In Les Peuple sans-culotte, imagery is omnipresent. The second paragraph opens with:

No! we will not abandon you. No, you will not be made to suffer under the irons of foreign kings ... ${ }^{355}$

The imagery here is not subtle. This is a language of combat and resistance.

Claude Lévi-Strauss argues that the combative aspect of the language is an intermediary between images and concepts. The words (signs) made to suffer under the irons are powerful because they resemble images that are concrete entities. However, their force is increased because these signs also approximate concepts in their reference. Neither the concept of suffer, however, nor the sign that relates linguistically to the concept associate exclusively to themselves. Either may be substituted for something else. Concepts, however, have an unlimited capacity in this respect, while signs have not. ${ }^{356}$ The decision as to what to put in each place also depends on the possibility of putting a different element there instead. Lévi-Strauss argues that each choice which is made will involve a complete reorganization of the structure. ${ }^{357}$ Concepts, for Lévi-Strauss, appear like operators 'opening up the set being worked with and signification like the operator of its reorganization,' which

355 Ibid., 1.

${ }^{356}$ Claude Lévi-Strauss, The Savage Mind, (Chicago, University of Chicago Press, 1962), 299. ${ }^{357}$ Ibid., 300 . 
'neither extends nor renews it and limits itself to obtaining the group of its transformations. ${ }^{, 358}$ However, the linguistic concepts are not defined by the author alone. With each reading and reader a new concept is constituted. This new concept remains just as inherently viable and authoritative as the originary meaning of the author. There is no single intent or construct inherent in Babeuf's writing. There are, rather, an unlimited array of imaginary possibilities.

Images like under the irons of foreign kings cannot be ideas for Lévi-Strauss. They can, however, play the part of signs or, to be more precise, "co-exist with ideas." ${ }^{359}$ Lévi-Strauss reject the singularity of ideas and argues that only 'images are fixed, linked in a single way to the mental act which accompanies them.' Unlike concepts, images do not possess simultaneous and theoretically unlimited relations with other entities of the same kind. ${ }^{360}$

Jacques Derrida, however, dispensed the traditional 'established' categorization of human knowledge and consciousness. Derrida intensified his focus upon the inherent contradiction within language and the text. Derrida interprets the inconsistencies rather than the apparent coherent messages of the text. ${ }^{361}$ For Derrida, 'knowledge is not a systematic tracking down of a truth that is hidden but may be

${ }^{358}$ Ibid.

${ }^{359}$ Ibid.

${ }^{360}$ Ibid., 301.

${ }^{361}$ Appleby, Knowledge and Postmodernism in Historical Perspective, 386. 
found. It is rather the field 'of freeplay', that is to say, a field of infinite substitutions in the closure of a finite ensemble.' 362

Language to Derrida is more impersonal that Lévi-Strauss. It exceeds the individual by its universal use. To speak with other involves, or in the case of Les Peuple sans-culotte, writing, involves inevitably the surrender of a portion of the uniqueness of our language in deference to the understanding and comprehension of others. ${ }^{363}$ The presentation, therefore, the imagery of the 'slavish irons of foreign kings' cannot be examined solely as a representation of the sans-culotte. Derrida argues that the text, like speech, transcends the intent of the original possessor when it passes from the personal and internal message to public statement. Text, and therefore the imagery and meaning of the text, is freed from the author when it is committed to strangers for reading and interpretation. The problematic aspect of this interpretation is that it denies any notion of authorial intent and purpose. The originary meaning is denied to promote a form of scholasticism that allows for the introduction of anachronistic ideology.

Structuralism, however, is an attempt to isolate the general structures of human activities. In the activities of linguistics and history, the structure composes a unit of a few elements invariably discovered within their similar relational activities. Regardless that this structure is forged by units, these units cannot be broken down

${ }^{362}$ Jacques Derrida, L'écriture et la différence, (Paris, 1967), 423.

${ }^{363}$ Ibid., 12. 
into single elements that are not independently translatable. ${ }^{364}$ The structure , therefore, of Babeuf's pamphlets is defined not by its 'substantive nature' but the elemental and inter-relational activity of its language.

It is from this theoretical basis that the following analysis of the journalistic career and language of Gracchus Babeuf is produced. Having established that an analysis of language is the only venue to examine the revolutionary ideology of Babeuf, the argument arises over the method and value of this criticism. By examining language as a medium of political intention requires the formulation of a specific methodology defined as linguistic structural-determinism. It is a system based on the notion that the construction of a language within a given medium can be examined to establish the meaning, purpose, and politics of printed matter.

In reading the works of Babeuf, it becomes evident that the structure of these pamphlets, as shown in both the language and the internal construction, governs the message and discourse. The examination of The language of Babeuf must be seen as the creation of eighteenth-century society. The structure and subjectivity explicit in these writings, therefore, refutes the post-modernist implication of the proliferation reality. Babeuf conceived of Les battus payant amende, On veut sauver Carrier and Voyage des jacobins as a commentary on the Thermidorian regime and the corruption of Robespierre and the Jacobins. To read back into these pamphlets any extraneous

${ }^{364}$ Ibid., 1. 
political ideology is to undermine the validity and authority of Gracchus Babeuf as a critic and impassioned observer of the French Revolution.

This paper will show that there is both a cultural and historical determination evidenced within the structure of Babeuf pamphlets. The revolutionary language and discourse, the tone and metaphor, and the rhetoric and allusion utilized by Gracchus Babeuf in his Le Tribun du Peuple, Voyage des jacobins, Les battus payant amende, and On veut sauver Carrier were not effective in providing a radical voice to the moderate political culture of post-Robespierrest Revolution, it also succeeded in winning Babeuf arrest, trial, and execution. 


\section{BIBLIOGRAPHY}

PRIMARY SOURCE DOCUMENTATION:

Babeuf, François-Noël. C. Fournier (L'Americain) à Marat. (Paris: Mayer, 1793). . Le Journal de la liberté de la presse, no 1. (Paris: Guffroy, 1794).

Le Journal de la liberté de la presse., no 10. (Paris: Guffroy, 1794).

Babeuf, F.-N. 'Gracchus.' Le Journal de la liberté de la presse, no 21. (Paris: Guffroy, 1794).

Les battus payant amende: ou les jacobins jeannots. (Paris: Frankin, rue de Clery 75, 1794).

-Voyage des jacobins dans les quatre parties du monde: avec la

Constitution mise à la ordre du jour par Audouin et Barrère. (Paris: Franklin, rue de Clery 75,1794$)$.

- On veut sauver Carrier: On veut faire le procès au Tribunal révolutionnaire. Peuple prend garde à toi! (Paris: Franklin, rue de Clery 75, 1794).

Le Tribun du Peuple. $\mathrm{n}^{\circ} 28$. (Paris: Franklin, rue de Clery 75, 1795).

Le Tribun du Peuple, $\mathrm{n}^{\circ} 29$. (Paris: Franklin, 1794).

Le Peuple sans-culotte de Paris à la légion de Police. (Paris, 1795).

G. Babeuf/Tribun du Peuple à ses Concitoyens. (Paris: Franklin, rue de

Clery 75, 1795).

-Le Tribun du Peuple. $\mathrm{n}^{\circ}$ 34. (Paris: R. Lebois, Imprimerie de l'Ami du Peuple, 1796).

-The Defense of Gracchus Babeuf before the High Court of Vendôme. trans.

John A. Stewart, intro. Herbert Marcuse. (New York: Schocken Books, 1967).

Barère, Bertrand. L'Acte d'accusation contre Carrier présenté aux Comités réunis, à la Convention nationale et au peuple français. (Paris, An III).

Dupuis, representative of the people, Motifs de l'acte d'accusation contre Carrier, (Paris, An III). 
SECONDARY SOURCE DOCUMENTATION:

Appleby, Joyce, et al., Knowledge and Postmodernism in Historical Perspective. (New York, London, Routledge, 1996).

Aulard, Alphonse'Babeuf et son Imprimeur Guffroy.' Annales Historiques de la Révolution Française. Vol. LXXXIII, (1929). pp. 6-24.

- Christianity and the French Revolution. Trans by Lady Frazer. (New York: Howard Fertig, 1966).

Baczko, Bronislaw. Ending the Terror: The French Revolution after Robespierre. Trans. by Michel Petheran. (Cambridge: Editions de la Maison des Sciences de l'Homme and Cambridge University Press, 1994).

Baker, Keith M. "Politics and Public Opinion Under the Old regime: Some Reflections." Press and Poltics in Pre-Revolutionary France. ed. by J. Popkin and J. Censor. (Los Angeles and Berkeley: Universioty of California Press, 1987).

Blanning, William. The Rise and Fall of the French Revolution. (Chicago and London: University Press, 1996).

Bertaud, Jean-Paul. "La Presse en l'an II: Aperçu des recherches en cours." Annales Historiques de la Révolution Française. $\mathrm{n}^{\circ} 2$ 2, (1995). pp. 161-172.

Cabet, Etienne. Histoire populaire de la Révolution française. Vol IV. (Paris: 1840). Censor, Jack. Prelude to Power. (Baltimore, Md.: 1976).

. The French Revolution and Intellectual History. (Chicago: University Press, 1989).

Chartier, Roger. Histoire de la vie privée (vol. III): de la renaissance aux lumières, Phillipe Ariès and George Duby, eds. (Paris, Seuil, 1986).

. Forms and Meaning: Texts, Performances, and Audiences from Codex to Computer. (Philadelphia, Univeristy of Pennsylvania Press,1995).

Cobb, Richard. "L'Arrestation de Babeuf à Paris, le 20 pluviôse, an III" Annales Historiques de la Révolution Française. ${ }^{\circ}$ 165, (1961) pp. 393-94.

Coët, Emile. Babeuf à Roye. (Peronne: 1885).

Daline, Victor. "Robespierre et Danton vus par Babeuf." Annales Historiques de la Révolution Française. Vol. 162, (1960). pp. 388-410.

—. "L'Historiographie de Babeuf." La Pensée. Vol. 128, (1966). pp. 69-101.

Darnton, Robert. The Literary Underground of the Old Régime. Cambridge Mass and London: Harvard University Press, 1982).

Dautry, Jean. "Georges Lefebvre et le babouvisme." Annales Historiques de la Révolution Française. Vol. 32, n 1. (1960). pp. 47-56.

Dawson, Christopher. Gods of the French Revolution. intro Arnold Toynbee. (New York, New York University Press, 1972).

Derrida, Jacques. L'écriture et la différence. (Paris, 1967). 
. Marges de la Philosophie. (Paris, 1972).

. Of Grammatology. trans Gayatri Chakravorty Spivak.

(Baltimore and London, Johns Hopkins University Press, 1977).

Desan, Suzanne. "Redefining Revolutionary Liberty: The Rhetoric of Religious

Revival during the French Revolution." The Rise and Fall of the French

Revolution. ed William Blanning. (Chicago: University Press, 1989).

Dézamy, Theodore. "Calomnies et politique de M. Cabet. Réfutation par des faites et par sa biographie." Sur l'attitude de Cabet envers Babeuf et le babouvisme.

(Paris: 1842).

Dommanget, Maurice. Pages choisies de Babeuf. (Paris: Libarie de Armand Colin, 1935).

"Babeuf et l'éducation." Annales Historiques de la Révolution Française, Vol. 162, n ${ }^{\circ}$. (1960). pp. 534-39.

Fehér, Ferenc. The Frozen Revolution: An Essay on Jacobinism. (Cambridge:

University Press, 1987).

Furet, François. Interpreting the French Revolution. trans Elborg Foster. (Cambridge:

University Press, 1986).

. "Miarabeau." Critical Dictionary of the French Revolution. ed. François

Furet and Mona Ozouf, (Cambridge and London: Belknap Press of Harvrad

University Press, 1989).

Gallois, L. Histoire des journaux et des journalistes de la révolution française.

2 Vol. (Paris, 1846).

Gendron, François. La Jeunesse dorée sous Thermidor. (Paris: Les Presses

Universitaires de France, 1983).

Godechot, Jacques. "Les travaux récents sur Babeuf et le babouvisme." Annales

Historiques de la Révolution Française. Vol 32, n 4. (1960) pp. 370-387.

Gordon, Daniel. "'Public Opinion' and the Civilizing Process in France: The

Examples of Morellet." Eighteenth-Century Studies. Vol. 22, Number 3,

(Spring 1989).

pp. 302-328.

Gough, Hugh. The Newspaper Press in the French Revolution.

(Chicago: Dorsey Press, 1988).

Habermas, Jurgen. The Structural Transformation of the Public Sphere: An Inquiry

into a Catagory of Bourgeois Society. trans Thomas Burger. (Cambridge:

Mass., 1989).

Hawkes, Terence. Structuralism and Semiotics. (Berkeley and Los Angeles,

University of California Press, 1977).

Hesse, Carla. "Reading Signatures: Female Authorship and Revolutionary Law in France, 1750-1850." Eighteenth-Century Studies. Vol. 22, Number 3, (Spring 1989). pp. 469-487. 
Publishing and Cultural Poltics in Revolutionary Paris, 1789-1810.

(Berkeley, Los Angeles, and Oxford: University of California Press, 1991).

Hunt, Lynn A. Politics, Culture, and Class in the French Revolution. (Berkeley:

Los Angeles: University of California Press, 1984.

. "Introduction: The French Revolution in Culture: New Approaches and

Perspectives." Eighteenth-Century Studies. Vol. 22, Number 3, (Spring 1989).

pp. 293-301.

Jones, Adrian. "Towards a New Structiural Theory of Revolution: Universalism and

Continuity in the French and Russian Revolutions." European Historical

Review. (October, 1992). pp. 862-900.

Kantorowicz, Ernst. The King's Two Bodies. (Princeton: University Press, 1957).

Kates, Gary. The Cercle Social, the Girondins, and the French Revolution.

(Princeton: University Press, 1985).

Lefebvre, Georges. The French Revolution from 1793-1799. Vol II. trans John Hall

Stewart and James Friguglietti. (New York: Columbia University Press, 1964).

- Les Thermidoriens. (Paris: Max Leclerc et Cie, 1964)

- Le Directoire. (Paris, Max Leclerc et Cie, 1946).

Lévi-Strauss, Claude. The Savage Mind. (Chicago, University of Chicago Press, 1962).

\section{. Structural Anthropology. tran. Claire Jacobson.}

(New York, Anchor Books, 1967).

Liberman, Anatoly. "Introduction." Theory and History of Folklore, Vladimir Propp. trans. Ariadna Y. Martin and Richard P. Martin, ed. Anatoly Liberman.

(Minneapolis,Univ. Of Minnesota Press, 1984).

Lucas, Colin. "The First Directory and the Rule of Law." French Historical Studies, Volume X, Number 2, (Fall 1977). pp. 231-260.

- "The Crowd and Politics between Ancien Régime and Revolution in France." The Rise and Fall of the French Revolution. ed William Blanning. (Chicago: University Press, 1989).

Lyons, Martyn. "M.G.A.-Vadier (1736-1828) The Formation of the Jacobin Mentality." French Historical Studies. Vol. 10, Number 1, (Fall 1977). Mannhiem, Karl, "The Problem of the Intelligensia," Essays on the Sociology of Culture (New York: Oxford University Press, 1956).

Marx, Karl and Engels, Frederich. La Sainte famille. (Ouveres, tome II). Mathiez, Albert. After Robespierre: The Thermidorian Reaction. trans Catherine Alison Phillips. (New York: Grosset \& Dunlap, the Universal Library, 1965).

. The French Revolution. trans Catherine Alison Phillips. (New York: Grosset and Dunlap, 1956).

Mazauric, Claude. "Le Rousseauisme de Babeuf." Annales Historiques de la Révolution Française. Vol 170, $\mathrm{n}^{\circ}$ 2. (1962). pp. 439-464. 
Nathans, Benjamin. 'Habermas's 'Public Sphere' in the Era of the French

Revolution." in French Historical Studies, Vol. 16, Number 3, (1990) pp. 620-664.

Ozouf, Mona. "Public Opinion' at the End of the Old Régime." The Rise and Fall of the French Revolution. ed William Blanning. (Chicago: University Press, 1989).

- "War and Terror in French revolutionary Discourse (1792-1794)." The Rise and Fall of the French Revolution. ed William Blanning. (Chicago: University Press, 1989).

Palmer, R. R. The Twelve Who Ruled. (Princeton: University Press, 1969).

Popkin, Jeremy. "Pamphlet Journalism at the End of the Old Regime." EighteenthCentury Studies. Vol. 22, Number 3, (1989). pp. 351-367.

- "Journals: The New Face of News." Revolution in Print: The Press in France, 1775-1800. ed. Robert Darnton and Daniel Roche. (Berkeley, Los Angeles and London, University of California Press, 1989). - "The Press and the French Revolution after Two Hundred Years." French Historical Studies, Vol. 16, Number 3, (1990) pp. 664-683.

- Revolutionary News: The Press in France, 1789-1799. (Durham and London: Duke University Press, 1990).

Prévost, M et R. D’Amant. Dictionnaire de biographie française, Tome 17, (Paris: Libarie Letouzet et Ané, 1981).

Propp, Vladimir. Theory and History of Folklore. Trans by Ariadna Y. Martin and Richard P. Martin. ed Anatoly Liberman. (Minneapolis, Univ. Of Minnesota Press, 1984).

Rose, R.B. The Enragés: Socialists of the French Revolution? (Melbourne:

University Press, 1965).

- Gracchus Babeuf: The First Revolutionary Communist. (Stanford:

University Press, 1978).

Sewell, Willaim H., Jr. "Ideologies and Social Revolution: Reflextions on the French

Case." The Rise and Fall of the French Revolution. ed William Blanning. (Chicago: University Press, 1989).

Sobul, Albert. The French Revolution, 1789-1799: From the Storming of the Bastille to Napoleon. (New York: Random House, 1974).

Sturrock, John. Structuralism and Since. (Oxford, Oxford University Press, 1979).

Tønnesson, Kåre D. La Défaite des sans-culottes. (Paris: Librairie R. Clavreuil, 1959). - "L'An III dans la formation du babouvisme." Annales Historiques de la Révolution Française. Vol 32, $\mathrm{n}^{\circ} 4$. (1960). pp. 411-435.

Van Kley, Dale. "New Wine in Old Wineskins: Continuity and Rupture in the Pamphlet Debate of the French Prerevolution, 1787-1789." French Historical Studies. Vol. 17, Number 2, (1991). pp. 38-61. 
The Religious Origins of the French Revolution. From Calvin to the Civil Constitution: 1560-1791. (New Haven and London: Yale University Press, 1996),

Vandal, Albert. L'Avèncement de Bonaparte. 17th edition. (Paris, Plon, Nourrit, 1912). Vico, Gianbiattista. Nouvo Scienza. Trans by Thomas Goddard Bergin and Max Harold Fish, The New Science of Gianbiattista Vico: Unabridged Translation of the Third Edition (1744) with the addition of "Practice of the New Science" (Ithica, N.Y.,Cornell University Press, 1984).

Woloch, Isser. Jacobin Legacy: The Democratic Movement Under the Directory. (Princeton, Princton University Press, 1970).

Woronoff, Denis. The Thermidorian regime and the Directory 1794-1799. trans Julian Jackson. (Cambridge, New York: Cambridge University Press, 1984). 